University of Michigan Law School

University of Michigan Law School Scholarship Repository

Articles

Faculty Scholarship

$12-1974$

\title{
Legislative Regulation of Searches and Seizures: The Michigan Proposals
}

Jerold $\mathrm{H}$. Israel

University of Michigan Law School, israelj@umich.edu

Follow this and additional works at: https://repository.law.umich.edu/articles

Part of the Criminal Procedure Commons, Law Enforcement and Corrections Commons, Legislation Commons, and the State and Local Government Law Commons

\section{Recommended Citation}

Israel, Jerold H. "Legislative Regulation of Searches and Seizures: The Michigan Proposals." Mich. L. Rev. 73 (1974): 221-316.

This Article is brought to you for free and open access by the Faculty Scholarship at University of Michigan Law School Scholarship Repository. It has been accepted for inclusion in Articles by an authorized administrator of University of Michigan Law School Scholarship Repository. For more information, please contact mlaw.repository@umich.edu. 


\title{
LEGISLATIVE REGULATION OF SEARCHES AND SEIZURES: THE MICHIGAN PROPOSALS
}

\author{
Jerold $H$. Israel
}

I. Probability Requirements $\ldots \ldots \ldots \ldots \ldots \ldots \ldots \ldots .226$

A. Probable Cause for a "Full Search" .......... 226

B. Other Probability Requirements .......... 227

1. Inspections ................... 227

2. Frisks . ..................... 229

3. Investigative Stops ................ 231

4. Nontestimonial Identification Orders ....... 238

II. Warrantleess Searghes $\ldots \ldots \ldots \ldots \ldots \ldots \ldots \ldots \ldots$. 241

III. Facilitating the Use of Search Warrants ....... 249

A. Safeguards Versus Facilitation ............ 253

B. Facilitating the Warrant Application ......... 255

1. Availability of Magistrates ............ 256

2. Telephonic Search Warrant Applications ..... 258

3. Affidavit Contents .................. 263

4. Expanded Scope of Search and Seizures ....... 266

5. Ordinance Violations .............. 271

C. Executing Warrants ................ 273

IV. Execution Provisions $\ldots \ldots \ldots \ldots \ldots \ldots \ldots \ldots \ldots .278$

A. Notification of Authority ............... 279

B. Entry Without Consent ............... 289

C. Use of Force .................... 289

D. Receipt ...................... 292

E. Disposition of Seized Property .............. 295

V. EXCLUSIONARY REMEDY ................. 298

Appendix: Proposed Provisions on Search and Seizure 301 


\title{
LEGISLATIVE REGULATION OF SEARCHES AND SEIZURES: THE MICHIGAN PROPOSALS
}

\author{
Jerold H. Israel*
}

$I^{\mathrm{s}}$ N March 1971, the Michigan Bar Commissioners appointed a twenty-five-member committee with a directive "to promulgate a recommended revision of the Code of Criminal Procedure codifying existing statutory and case law provisions which, in the judgment of the Committee, should be retained and adding thereto such provisions as the Committee, in its judgment, deems warranted; and to incorporate such recommendations into proposed legislation for submission to the Legislature."1 The committee membership included judges, prosecutors, legislators, criminal defense lawyers, law school professors, and representatives of Michigan police and corrections agencies. ${ }^{2}$ Judge Horace Gilmore served as Chairman, and I served as Reporter.

After twenty day-long meetings over a two-year period, the Committee temporarily concluded its work with proposed statutes on

* Professor of Law, University of Michigan, B.B.A. 1956, Western Reserve University; LL.B. 1959, Yale University.-Ed.

1. Letter from Charles Joiner, President of the State Bar of Michigan, to the author, March 30, 1973. The Committee was supported by a grant from the Michigan Office of Criminal Justice Programs under the Federal Omnibus Crime Control and Safe Streets Act of 1968, 82 Stat. 197 (codified in scattered sections of 5, 18, 28, 42, 47 U.S.C.).

The Committee did not reexamine the appropriate division of authority between court rule and legislation, but simply followed the current legal structure. The Committee presented its recommendations in the form of proposed legislation because the current provisions on search and seizure are contained in the Michigan Code of Criminal Procedure. In some jurisdictions many of the subjects treated in the proposed statute (e.g., the subjects of sections $2,4,5,7$, and 9 ) are governed by court rule.

2. Members who were legislators did not actively participate in the committee mectings because the proposals would eventually be submitted to their legislative committees. Other committee members included: private attorneys Ivan E. Barris, Harry $\mathbf{L}$. Pliskow, James Renfrew, Myzell Sowell (Chief Defender of the Detroit Legal Aid and Defender's Association), Sheldon Toll, and Joseph Wilcox; prosecuting attorneys William L. Cahalan (Wayne County) and James K. Miller (Kent County); James Shonkwiler (Executive Director, Prosecuting Attorneys Association); Judges Thomas G. Kavanagh (Supreme Court), Timothy Quinn (Court of Appeals), Horace Gilmore (Wayne County Circuit), Donald Reisig, (Ingham County Circuit), Joseph Sullivan (Wayne County Circuit), Geraldine Ford (Recorder's Court), Donald Leonard (Recorder's Court), and Daniel Walsh (initially District Court, Gaylord, and now Court of Appeals); Marcell Greenia, Director of Legal Services, Supreme Court; Department of Corrections officials Gus Harrison (former Director), Perry Johnson (Director), and Roy Nelson (Deputy Director); police officials John Brown (Colonel, Michigan State Police), Kenneth Preadmore (Sheriff, Ingham County), and John Nichols (former Detroit Police Commissioner); and Professors B.J. George (Wayne State University) and Jerold Israel (University of Michigan). Myzell Sowell often was represented at meetings by George Grockett, III; William Cahalan was represented by James Garber and Richard Padzieski; Perry Johnson was represented by Edward Turner; and John Nichols was represented by William Morris and Richard McKnight.

[222] 
Search and Seizure, Arrest, Disposition of Arrested Persons, Appearance Tickets, Summons, Grand Jury Operations, and Prosecution Investigatory Depositions. What follows is a modified version of the Reporter's Commentary on the proposed statute dealing with "Search and Seizure." (The statute appears in an appendix to this article.) I have attempted to restate the major arguments advanced by Committee members in support of the statute, and where the Committee was sharply divided on a particular policy issue, to restate the positions advanced by the dissenters.

Various factors contributed to the selection of search and seizure as the initial topic for Committee consideration. First, although the Michigan Code of Criminal Procedure provisions on search warrants ${ }^{3}$ were revised as recently as 1966, developments since then necessitated reconsideration of at least some portions of that revision. The drafters of the 1966 provisions obviously had not anticipated Supreme Court decisions that expanded the area in which warrants are constitutionally required for a valid search. Furthermore, a significant increase in the use of warrants, particularly in connection with household searches, had produced a corresponding increase in administrative burdens that previously were viewed as too insignificant to merit legislative consideration. ${ }^{4}$

Second, the 1966 revision dealt only with search warrants; there had been no reexamination of the legislative treatment of warrantless searches since the complete code revision of 1927. In the meantime, both the practice and precedents relating to warrantless searches had dramatically changed.

A third factor was the availability of legislative materials that could serve as helpful models in drafting. In particular, the American Law Institute's Model Code of Pre-Arraignment Procedure 5 extensively considers all aspects of search and seizure. Recently adopted state procedural codes also include substantial provisions on several aspects of search and seizure. ${ }^{6}$

Finally, the Committee recognized that time limitations would

3. Mich. CoMp. LAws ANN. \$§ 780.651-.659 (1968).

4. Although statewide statistics were unavailable, the Detroit experience appeared fairly typical. The number of search warrants obtained annually in Detroit was estimated by the Wayne County Prosecutor's office to have jumped from less than 100 in 1968 to over 1800 in 1972 . Most of the increase has been attributed to Chimel v. California, 395 U.S. 752 (1969), particularly as it relates to household searches.

5. Alt Moder Code of Pre-Arraignment Procedure (Official Draft No. 1, 1972). [hereinafter ALI CoDE].

6. See, e.g., Ir. Rev. Stat. ch. 38, § 108-1 (1973); Kan. Stat. ANn. § 22-2501 (Supp. 1973); N.Y. CrIM. P. LAw § 690 (McKinney 1971); N.C. GEN. Stat. ch. 15A, arts: 9-10, $\S \S 15 A-221$ to -231 (effective July 1, 1975); Wrs. STAт. ANN. § 968.10 (1971). 
not permit reexamination of all aspects of pretrial procedure before its initial report was due. Search and seizure was particularly appropriate for initial consideration because the provisions relating to that area are largely self-contained. A significant revision of search and seizure law could be adopted without substantial alteration of provisions dealing with other components of criminal procedure.

The Committee concentrated primarily on possible legislative guidelines relating to five aspects of the law governing search and seizure: (1) the degree of probability of finding seizable items required to justify various forms of invasion of privacy that might be characterized as "searches"; (2) justifications for engaging in a search without first obtaining a search warrant, and the permissible scope of warrantless searches; (3) procedural requirements for obtaining a search warrant; (4) execution of searches and seizures both with and without warrants, including retention and disposition of seized matter; and (5) application of the exclusionary rule to bar use of evidence obtained through searches and seizures in violation of statutory standards. After examining each of these areas, the Committee decided to propose legislation only on the third and fourth topics, and on a limited aspect of the first topic.

In reaching this decision, the Committee appeared to be guided by certain basic premises as to the appropriate role of legislation in the area of search and seizure. The Committee generally assumed that those aspects of search and seizure law that are largely governed by constitutional limitations should be left to the courts. The primary role of legislation should be in areas, such as execution and administration, in which the courts generally have found no significant constitutional requirements or only general requirements that grant the states considerable leeway in fashioning guidelines. Committee members frequently contended that proposed legislation that merely repeats judicially developed constitutional standards carries a burden of special justification. Such legislation adds nothing to the present substance of the law, and might well prove pernicious if subsequent judicial decisions alter constitutional standards. If later decisions grant the police less leeway in conducting searches, the existence of the broader legislative standard might cast doubt even on activities that comply with the new decisions. At times courts have seemed to be as concerned with the constitutionality of the legislative authorization under which police acted as with the police activity itself. ${ }^{7}$ If subsequent decisions expand police

7. See, e.g., Berger v. New York, 388 U.S. 41 (1967); United States v. Whitaker, 
authority, the legislature may find that it has imposed more restrictive limits than it otherwise would have thought desirable. When codifying a judicially developed constitutional limitation, the legislature is unlikely to examine the subject in such detail as to be certain that any future judicial dilution of that limitation would necessarily be unacceptable as a matter of public policy.

Notwithstanding this general concern, the Committee recognized that there are instances in which legislation can appropriately address topics governed largely by constitutional limitations. Where current judicial guidelines authorize searches deemed undesirable as a matter of public policy, more restrictive legislative guidelines ordinarily are required. Similarly, where a particular practice is viewed as desirable but its constitutionality has been questioned, legislative approval may help in gaining ultimate judicial approval. ${ }^{8}$

The Committee also appreciated the administrative benefits provided by a code so comprehensive as to include all of the basic guidelines (constitutional and nonconstitutional) applicable to a particular subject. Most members viewed such a task as more appropriate for a treatise or a Model Standards project, but they were willing to support it to a limited extent. A legislative restatement of current constitutional standards would be acceptable if it could provide specific guidelines sufficient to lend substantial assistance to magistrates and prosecutors without requiring a detailed examination of judicial opinions. It was generally agreed, however, that this criterion would not be met by simply adding a "shopping list" of factors that might be considered on a case-by-case basis in applying a general constitutional standard. Such enumerations frequently are based on a series of appellate decisions that illustrate the applicability of particular factors in a far better fashion than a legislative listing that strips those factors from the context in which they were developed. ${ }^{9}$ Indeed, a legislative listing of potentially relevant factors is

343 F. Supp. 358 (E.D. Pa. 1972), revd., 474 F.2d 1246 (3d Cir.), cert. denied, 412 U.S. 953 and sub nom. Perrerra v. United States, 412 U.S. 950 (1973). But see Sibron v. New York, 392 U.S. 40, $62-63$ (1968); United States v. Cafero, 473 F.2d 489 (3d Cir. 1973).

8. See, e.g., text at notes 75-76 infra. Cf. Kamisar, Kauper's "Judicial Examination of the Accused" Forty Years Later-Some Comments on a Remarkable Article, 73 MIcr.' L. REv. 15, 33-34 n.70 (1974). In a few areas there may be reason to believe that legislative authorization might even gain judicial acceptance of practices previously held invalid. See note 306 infra.

9. The Committee recognized that such listings may be more appropriate in police regulations, where specific examples can be provided to illustrate the weight a certain factor should receive in a particular case. See, e.g., Project on LAw ENForgement Policy and Rulemaring, Moder Rules: Stop and Frisk (1973) [hereinafter PLE MOdeL RuLes]. See also Quinn, The Effect of Police Rulemaking on the Scope of Fourth: 
often misleading, even as a restatement of constitutional standards, because it fails to reveal that certain elements often tend to be far more important than others.

\section{Probability Requirements}

The Committee considered various proposals relating to the degree of probability needed for different forms of searches, including the extensive provisions in the ALI Code. The Committee concluded that, aside from the area of court orders directing participation in nontestimonial identification procedures, adoption of legislation attempting to define probability requirements would be inappropriate at this time.

\section{A. Probable Cause for a "Full Search"}

The nature of the "probable cause" needed to justify a "fullfledged" search has been the subject of considerable discussion in Michigan and federal decisions. Those decisions have not established a specific required quantum of probability, such as the "more-probable-than-not" standard that concerned the Reporters for the ALI Code. ${ }^{10}$ Instead, most simply have emphasized that probable cause consists of more than "mere suspicion" (that is, more than an assumption of probability not supported by objective facts)..$^{11}$ Several decisions, attempting to provide a more precise definition, have described probable cause as a probability sufficiently "substantial"12 or "reasonable" to justify a search in the judgment of a "prudent and careful person, having due regard for the rights of others."13 What

Amendment Rights, 52 J. URBAN L. 25 (1974), proposing a rulemaking procedure that would require a case-by-case development of fourth amendment standards. A listing of rèlevant factors may also be appropriate in a provision governing an area such as bail, in which there are likely to be few appellate decisions illustrating the appropriate applications of the factors. See, e.g., 18 U.S.C. \& 3146(b) (1970).

10. See ALI CoDE, supra note 5, at 133-36.

11. See, e.g., Brinegar v. United States, 338 U.S. 160, 177 (1949); People v. Walker, 385 Mich. 565, 575, 189 N.W.2d 234, 239 (1971).

12. See People v. Iaconis, 29 Mich. App. 443, 454, 185 N.W.2d 609, 614 (1971), affd. sub nom. People v. Bercheny, 387 Mich. 431, 196 N.W.2d 767 (1972).

13. People v. Miller, 245 Mich. 115, 118, 222 N.W. 151, 152 (1928). See also People v. Goss, 246 Mich. 524, 224 N.W. 364 (1929); People v. Smith, 43 Mich. App. 400, 407, 204 N.W.2d 308, 312 (1972).

The term "reasonable cause" rather than "probable cause" is used in the proposed draft, but the same degree of probability applies to both terms under Michigan decisions and statutes. See People v. Siemieniec, 368 Mich. 405, 407, 118 N.W.2d 430, 432 - (1962); People v. Harper, 365 Mich. 494, 499-500, 113 N.W.2d 808, 811, cert. denied, 371 U.S. 930 (1962); People v. LaTeur, 39 Mich. App. 700, 703, 198 N.W.2d 727, 729 (1972); Mich. CoMp. LAwS ANN. §§ 28.433, 780.651 (1968), 325.455(2) (Supp. 1974-1975). See also ALI CODE, supra note 5, at 163-64. The Committee selected the phrase "reason- 
constitutes a sufficiently substantial or reasonable degree of probability may vary with such factors as the nature and purpose of the search and the use of the warrant. ${ }^{14}$ A legislative definition that merely restates such generalities would add little to the current body of law; ${ }^{15}$ yet a more exact definition could not be provided without examining specific fact situations. ${ }^{16}$ Even then, legislation could do little more than provide a "shopping list" of potentially relevant factors-a function the Committee generally viewed as inappropriate for legislation. ${ }^{17}$

\section{B. Other Probability Requirements}

The key issue facing the Committee in considering probability requirements was whether it should propose legislation authorizing limited searches based upon a standard less stringent than probable cause. Possible subjects of legislation were the regulatory inspection, the frisk incident to a temporary stop, and the obtaining of identification evidence (e.g., hair or blood samples) upon court order. The Committee decided not to treat the first two subjects, but section 22 of the proposed statute provides for issuance of identification orders on a "group probable cause" basis.

\section{Inspections}

The Committee concluded that the guidelines governing inspection searches should vary according to the nature of the inspection involved. The same standards need not apply to the inspection of households to determine whether there has been compliance with building code standards and the inspection of a weapons dealer's

able cause" because it is the phrase most frequently used in the current provisions. Cf. id. § SS 210.1.

14. See, e.g., People v. White, 54 Mich. App. 342, 220 N.W.2d 789 (1974); People v. Kremko, 52 Mich. App. 565, 218 N.W.2d 112 (1974). See also text at notes 126, 190, 200 infra.

15. See, e.g., ALI CoDE, supra note 5, § SS 210.1(7) (" "Reasonable cause to believe" means a basis for belief in the existence of facts which, in view of the circumstances under and purposes for which the standard is applied, is substantial, objective, and sufficient to satisfy applicable constitutional requirements."); Mrch. CoMp. LAws ANN. $\$ 300.12$ (1967) (governing conservation officers) ("For the purposes of this act, "probable cause' or 'probable cause to believe' shall be considered to be present on the part of a peace officer where there are facts which would induce any fair-minded man of average intelligence and judgment to believe that a law or statute has been violated or was being violated contrary to any of the aforesaid statutes or laws.").

16. See, e.g., People v. Parisi, 46 Mich. App. 322, 208 N.W.2d 70 (1973) (distinctive odors as basis for probable cause); People v. Hall, 40 Mich. App. 329, 198 N.W.2d 762 (1972) ("furtive gesture" or "evasive action" as basis for probable cause). See generally Cook, Probable Cause To Arrest, 24 VAND. L. REv. 317 (1971).

17. See text at note 9 supra. 
place of business to determine whether he is operating beyond his licensed authority. ${ }^{18}$ Greater flexibility should be permitted where, as in the case of the weapons dealer, violations are easily concealed and noncontinuous in nature, and the enterprise is "pervasively regulated" because of its unique and potentially dangerous nature. ${ }^{10}$ The numerous Michigan provisions that govern regulatory inspections vary considerably in describing the required grounds for inspecting a particular premises. For example, the provision that governs inspections for possible housing law violations ${ }^{20}$ requires that inspections be justified on a geographical area, complaint, or recurrent-violation basis. Other provisions apparently give the inspector authority to conduct random inspections at his discretion. ${ }^{21}$ The Controlled Substances Act of $1971^{22}$ requires that inspections be justified by "probable cause," which is said to exist "upon showing a valid public interest in the effective enforcement of this act or rules hereunder, sufficient to justify administrative inspection . . . in the circumstances specified in the application for the warrant." 28 The Committee concluded that any general guideline capable of application to most (if not all) regulatory inspections would be of limited value. The required probability standard would have to be so broad that it would add very little to the general judicial standards that already exist. ${ }^{24}$

18. Compare Camara v. Municipal Court, 387 U.S. 523 (1967), with United States v. Biswell, 406 U.S. 311 (1972).

19. United States v. Biswell, 406 U.S. 311, 315-16 (1972) (inspection of weapons dealer's locked storeroom pursuant to Federal Gun Control Act). In Biswell the Court upheld a warrantless inspection during business hours achieved without forcible entry. The Court held that, notwithstanding the absence of a warrant, the inspection constituted "reasonable official conduct under the Fourth Amendment." 406 U.S. at 316. In See v. Seattle, 387 U.S. 541 (1967), the Court had held that a warrant was constitutionally required for an inspection of a commercial warehouse for possible building code violations. In both See and Camara v. Municipal Court, 387 U.S. 523 (1972), the Court applied a "balancing" test in determining the applicable requirements of the fourth amendment. Biswell applied the same test, but found that the special factors of that case-particularly the limited expectation of privacy in such a "pervasively regulated business," the "essential" need for "unannounced, even frequent inspections" to deter regulatory violations, and the "large interests . . . at stake" in preventing such violations-justified dispensing with the warrant requirement. 406 U.S. at 316. See generally Greenberg, The Balance of Interests Theory and the Fourth Amendment: A Selective Analysis of Supreme Court Action Since Camara and See, 61 CALIF. L. REv. 1011 (1973). Presumably the same balancing analysis also would justify granting the weapons inspector far more leeway in selecting a particular dealer for inspection than would be granted the building inspector in selecting a particular household. $C f$. id. at 1022.

20. Mrar. Comp. Laws ANN. \& 125.526 (Supp. 1974-1975).

21. See, e.g., Mrch. CoMp. LAws ANN. $\$ \S 289.265$ (inspection of enterprises selling meat), 330.62 (1967) (mental hospital or residential facility).

22. Mrch. CoMP. LAWs ANN. \$\$ 335.301-.367 (Supp. 1974-1975).

23. Mich. CoMp. Laws ANN. \& 335.352(2) (Supp. 1974-1975).

24. See, e.g., AII CoDE, supra note 5 , § SS 250 (inspection must be in accordance 
Similar difficulties would be presented in drafting a standard governing the need for warrants in inspection searches. A few Michigan provisions require issuance of a warrant, but most do not. ${ }^{25}$ While some current statutes may be constitutionally defective in failing to require warrants, certain warrantless inspections clearly are constitutional. ${ }^{26}$ The ALI Code would establish a general policy requiring officials to seek consent for all inspections; if consent is denied, they must obtain an administrative or judicial warrant (unless an emergency exists). ${ }^{27}$ The Committee concluded that such a policy failed to give proper weight to the wide variations among different types of inspections in terms of the available personnel of the agency involved, the number of inspections, the scope of the inspections, and the need for immediate access to ensure that the inspection is effective. To test the ALI policy properly, each area of regulation would have to be examined separately by a group with some expertise as to agency operations. Inspection provisions are not designed or utilized primarily for criminal investigation, ${ }^{28}$ considerable weight must be given to their regulatory function apart from the use of possible criminal sanctions. The Committee concluded that an evaluation of that sort was beyond both its expertise and the task assigned to it by the Commissioners.

\section{Frisks}

The Committee also decided against proposing legislation governing police authority to "frisk" suspects who have not been arrested. There was considerable doubt as to the need for specific legislation on this topic. In Terry v. Ohio ${ }^{29}$ and Adams v. Williams ${ }^{30}$

with "reasonable legislative or administrative standards"). Cf. Mrch. CoMP. LAws ANN. \& 335.352 (Supp. 1974-1975), quoted in text at note 23 supra. Any proposed standard would also have to distinguish between "regulatory inspections" and those so-called "inspections" that are designed to uncover evidence of nonregulatory offenses. See, e.g., People v. Dajnowicz, 43 Mich. App. 465, 204 N.W.2d 281 (1973) ("inspection" for suspected arson).

25. Compare Mich. CoMp. LAws ANN. § 125.527 (Supp. 1974-1975) with MIch. Comp. LAWS ANN. § 289.265 (1967).

26. See, e.g., United States v. Biswell, 406 U.S. 311 (1972); Mich. Comp. Laws ANN. $\S 289.36$ (1967) (creameries inspection). Cf. Department of Natural Resources v. Seaman, 53 Mich. App. 192, 218 N.W.2d 813 (1974).

27. ALI CoDE, supra note $5, \S$ SS 250.

28. In most regulatory areas violations discovered through inspections would constitute misdemeanors. In several areas, however, prosecution may not be brought if the condition resulting in the violation is promptly eliminated. See, e.g., Mrch. CoMr. LAws ANN. $\$ 289.44$ (1967). In other areas the violation probably would not constitute a crime in any event. See, e.g., Mich. CoMp. LAws ANN. \$ 287.15a (1967). In at least one area, the current Code prohibits use of evidence obtained through an inspection in a criminal prosecution. See Mich. Conrp. Laws ANn. \& 286.461 (Supp. 1974-1975).

* 29. 392 U.S. I (1968).

30. 407 U.S. 143 (1972). 
the Supreme Court recognized the constitutionality of a protective "frisk" (a limited search of a suspect for the purpose of discovering weapons). In both cases the Court upheld protective frisks where the officer had a reasonable belief (a belief based upon rational inferences, but not amounting to probable cause) that the suspect was "armed and dangerous." 31 Michigan decisions have established that Michigan peace officers have inherent authority to frisk within the guidelines suggested by Terry and Adams. ${ }^{32}$

There would be little value in adopting legislation that merely restates the reasonable-belief standard of Terry and Adams. Yet, as with other probability requirements, to provide a substantially more specific standard, legislation would have to specify potentially relevant factors and define how they relate to different fact situations. ${ }^{83}$ Any legislative guideline also would have to specify the proper scope of the frisk. Here again it would be difficult to add to the guidelines provided in the Terry and Adams decisions. Although those cases leave open several issues relating to the permissible scope of the frisk, those issues are not of the type that can be resolved satisfactorily by a general statement of prohibition or authorization as is typically found in legislation. ${ }^{84}$

31. 392 U.S. at 30.

32. See, e.g., People v. Jeffries, 39 Mich. App. 506, 197 N.W.2d 903 (1972); People v. Piggee, 27 Mich. App. 367 (1970). The decisions have not expressed any concern about the lack of legislation specifically authorizing frisks. They apparently have assumed that the protective frisk is an essential aspect of the police officer's investigative authority and therefore the power to frisk is inherent in the creation of his office, Cf. LaFave, "Street Encounters" and the Constitution: Terry, Sibron, Peters, and Beyond, 67 Micr. L. REv. 39, 42-45 (1968); note 83 infra.

33. See text at notes 8-16 supra. See also PLE Moder RuLes, supra note 9. Model Rule 501 states the general probability standard commonly found in stop and frisk legislation: "[T] he officer reasonable [sic] suspects that the person is carrying a concealed weapon or dangerous instrument." Cf. N.Y. Crim. P. LAw § 140.50(2) (McKinney 1971); AlI CoDE, supra note 5, $\$ 110.2(4)$. However, Model Rule 502 goes on to list "some of the factors which-alone or in combination-may be sufficient to create 'reasonable suspicion' for a frisk." These include: whether the person's "clothes bulge in a manner suggesting the presence of any object capable of inflicting injury"; whether the person made "a furtive movement, as if to hide a weapon"; whether the person is suspected of involvement in a violent crime; whether the person has a record for weapons offenses; and whether the officer has detained a number of persons and lacks assistance. While such a listing may be appropriate for police regulations, the Committee did not view it as an appropriate format for legislation. See text at notes 8-9 supra. Also, police regulations often are drafted to include a limited number of factual examples that illustrate appropriate application of the listed factors. See note 9 supra.

34. One open issue relates to the extension of the frisk beyond the body of the person to include examination of a parcel (e.g., a purse or shopping bag) in the possession of a suspect reasonably believed to be armed. See United States v. Riggs, 474 F.2d 699, 704 (2d Cir.), cert. denied, 414 U.S. 820 (1973); Meade v. Cox, 438 F.2d 323 (4th Cir.), cert. denied, 404 U.S. 910 (1971). Arguably, examination of the parcel is unnecessary because it simply can be removed from the suspect's reach. Yet there may be situations in which the suspect first attempts to reach into the parcel, and the officer must respond 
Legislation would be desirable if one were convinced that the Terry and Adams standard granted excessive authority to the police. Those Committee members most concerned about the extensive use of frisks, however, largely agreed that the difficulty does not lie in the officer's authority to frisk for self-protection, but in his expansive authority to detain suspects. They believed that the best avenue of attack was to restrict the officer's "investigative stop" authority and thereby limit the situations in which there might be a need for a frisk. ${ }^{35}$ For reasons noted below, the Committee refused to propose such legislation.

\section{Investigative Stops}

Both state and federal decisions have upheld police authority to make investigative stops. While in Terry the Supreme Court refused to pass upon the constitutionality of the investigative stop apart from the seizure necessarily incident to a permissible frisk, the Court in Adams clearly indicated that an investigative stop is constitutionally acceptable apart from the frisk. The Court noted that a "brief stop of a suspicious individual, in order to determine his identity or to maintain the status quo momentarily while obtaining more information, may be most reasonable," 36 even though the officer "lacks the precise level of information necessary for probable

by feeling or opening it to ensure that it does not contain a weapon. Cf. LaFave, supre note 32, at 90. Even when the parcel is initially removed, it will be returned to the suspect if he is not arrested, and the officer may "reasonably suspect the possibility of harm if he returns such object unexamined." PLE Moder RULEs, supra note 9, Rule 605. Under this view the "frisk" cannot always be limited to the body of the person, but neither should it automatically extend to parcels without regard to the elements of the particular case. See id., Rules 601, 605.

Similar difficulties are presented in dealing with other aspects of the scope of the frisk-for example, may the officer directly reach into a certain portion of the suspect's clothing without "patting down" the outer clothing? ALI CODE, supra note 5, § 110.2(4) limits the frisk to a patting-down. But Adams clearly indicates that under the circumstances of that case, in which the officer was told that the weapon was in a particular location, it was permissible to "test" immediately the informant's reliability by reaching directly into the area in which the gun was supposedly hidden. There may be other situations in which it would also be appropriate, from the viewpoint of both the officer's safety and the suspect's privacy, to reach into a pocket or a similar area rather than to make a general pat-down.

35. See also ALI CoDE, supra note 5, at 103-28. One major proposal designed to prevent misuse of frisking authority could have been instituted apart from the regulation of "stop" authority-requiring that evidence obtained from a frisk, other than a dangerous instrument, be excluded. LaFave, supra note 32, at 91-92, suggests that the Supreme Court's disposition of Peters v. New York, 392 U.S. 40 (1968), a companion case to Terry, reflected the Court's desire to leave open this issue. See also People v. Dogans, 26 Mich. App. 411, 422 (1970). The Committee generally viewed the application of the exclusionary rule as a matter most appropriately left to judicial determination, see Part V infra, and saw no reason to create an exception in this area.

36. 407 U.S. at 146 . 
cause to arrest ...."37 The Court clearly was referring to coercive detention-the use of police authority to restrain a person-and not merely to an initiation of conversation where the person is free to leave. The Adams opinion cited with approval lower court cases ${ }^{88}$ involving coercive detention, and at one point spoke of the peace officer's authority to make a "forcible stop."30 Several Michigan decisions, relying on Terry and Adams, have held that an officer can make an investigatory stop on less than probable cause, and that such action is consistent with legislation requiring probable cause to make an "arrest."40

The Committee considered various legislative proposals that would define stop authority more fully than have judicial decisions, but concluded that adoption of legislation governing stops was inappropriate at this time. Initially the members agreed that the probability standard for a stop would not be a proper subject for legislative regulation. While the Supreme Court's opinions are not entirely clear, they strongly suggest that the officer needs approximately the same degree of probability for a stop as for a frisk: The officer must have a reasonable belief based upon rational inferences, although amounting to less than probable cause, that the suspect has engaged in, or is about to engage in, criminal activity. ${ }^{41}$ This level of probability is commonly referred to as a "reasonable suspicion standard."42 As with any standard that tests an actor's conduct against the judgment of a "reasonably prudent person" (including the standard of probable cause itself), there remains a good deal of uncertainty in application. As with the standard for a frisk, however, a legislative definition is unlikely to provide more guidance than the statements of the courts.

It has been suggested, however, that legislation could be useful with respect to other aspects of the authority to stop. Thus, the ALI

37. 407 U.S. at 145.

38. The Court cited Gaines v. Craven, 448 F.2d 1236 (9th Cir. 1971), and United States v. Unverzagt, 424 F.2d 396 (8th Cir. 1970), as illustrations of reasonable stops made by officers. 407 U.S. at 146.

39. 407 U.S. at 146.

40. See, e.g., People v. Whalen, 390 Mich. 672, 213 N.W.2d 116 (1973); People v. Hutton, 50 Mich. App. 351, 213 N.W.2d 320 (1973); People v. Parisi, 46 Mich. App. 322, 208 N.W.2d 70 (1973); People v. Rivers, 42 Mich. App. 561, 202 N.W.2d 498 (1972). See also note 32 supra.

41. See Adams v. Williams, 407 U.S. 143, $145-47$ (1972) (describing the level of probability needed for stops in terms similar to those used in Terry for frisks); J. Israel \& W. Lafave, Criminal Procedure in a Nutsherl 175-76 (1971) (discussing the significance of various passages in Terry).

42. See, e.g., People v. Hutton, 50 Mich. App. 351, 361, 213 N.W.2d 320, 324 (1973); ALI CoDE, supra note 5, at 122 . 
Code considers, inter alia: (1) whether the investigatory stop should be limited to investigations of the commission or potential commission of only serious crimes; (2) whether the length of the stop should be limited to a specific period (e. $. g .$, twenty minutes); (3) whether detention should be permitted only in public places; (4) whether the officer should have authority to remove the suspect from the initial point of the stop; (5) whether suspects should be warned of their rights upon being stopped, and given the Miranda warnings ${ }^{43}$ if questioned; (6) what degree of force may be used in making a stop; (7) whether the authority should extend to stopping individual automobiles and to the imposition of general roadblocks under some circumstances; and (8) whether the authority should extend to detaining: uncooperative material witnesses at the scene of the crime.44 Michigan decisions provide partial answers to some of these questions, ${ }^{45}$ but many remain unanswered except by reference to very general dicta.

The Committee recognized the need for further guidelines in this area, but concluded that this was an inappropriate time to adopt a legislative standard. Judicial decisions relating to investigative detention have taken a very cautious approach; rulings are largely limited to the facts of the particular case. Many Committee members believed that the paucity of relevant empirical data required that the Committee take a similarly cautious approach. They argued that insufficient information exists relating to the variety of situations requiring an investigative stop to determine, for example, the maximum permissible length of a stop or the need for investigative stops in connection with less serious crimes. ${ }^{46}$

43. See Miranda v. Arizona, 384 U.S. 436 (1966).

44. ALI Cone, supra note 5, at 3-14, 99-128.

45. See, e.g., People v. Whalen, 390 Mich. 672, 213 N.W.2d 116 (1973) (automobile stops); People v. Hutton, 50 Mich. App. 351, 213 N.W.2d 320 (1973) (Miranda warnings); People v. Parisi, 46 Mich. App. 322, 208 N.W.2d 70 (1973) (stop in connection with a suspected ordinance violation); People v. Rivers, 42 Mich. App. 561, 202 N.W.2d 498 (1972) (removal of the suspect from the initial point of contact).

46. At least some of the members concerned about the lack of data appeared to share the viewpoint expressed by Professor Conard in Macrojustice: $A$ Systematic Approach to Conflict Resolution, 5 GA. L. REv. 415, 426-27 (1971):

It is sad, I think, that [some] defenders of the Constitution have so little faith in its validity that they think it will be impaired by scientific investigation. For my own part, I believe that constitutional liberties can survive the probe of science. At the same time, I suspect our conceptions of them will be altered by scientific investigation-as have our conceptions of the earth, the heavens, and human mind.

...

... Every human value is bought at the price of some other human value, and we are destined to squander our patrimony of liberties like spendthrift heirs unless we find out what we are giving for what we are getting. For instance, with regard to search and seizures, if the police could not frisk suspects, there would be more dead policemen, and probably more dead citizens of other professions. At the other end of the spectrum, if policemen could also search the clothing of a selection of 
The most comprehensive studies of investigative stops relate to police activity before Terry, when stops may have been made more indiscriminately on the theory that the fourth amendment did not limit the authority to detain temporarily a pedestrian. ${ }^{47}$ Earlier studies also may not reflect the more rapid and systematic flow of information that has become available to patrol officers. ${ }^{48}$ Moreover, even if the available studies were considerably more current, they still would not reflect the full impact of certain recent developments. For example, in People v. Whalen ${ }^{40}$ the Michigan Supreme Court held that the Terry and Adams opinions permitted investigatory stops of moving vehicles on less than probable cause. In the past, police stops of "suspicious drivers" usually have been justified on the basis of alleged violations of the Motor Vehicle Code rather than on investigative stop authority. (If the police follow the driver over a short distance, they ordinarily will find that he has committed at least a technical violation of the traffic laws. ${ }^{50}$ ) It is too early to determine whether police will come to rely frequently upon the investigatory stop authority recognized in Whalen or will continue to rely upon traffic violations in stopping suspicious drivers. Committee members concerned about the unavailability of current data were fairly confident that information relating to various aspects of investigatory stops would become available as police adopt depart-

citizens, they could probably reduce gambling and drug traffic. If they could search cruising cars in the wee hours, they would probably reduce the number of burglaries. All of these are trade-offs; some are better than others. To know the terms of the trade, we ought to have some idea whether frisking, clothing searches, and automobile searches would be productive once in ten times, once in one hundred times, or once in one thousand times.

47. See, e.g., President's Commission on Law Enforcement and Administration of Justice, TAsK Force Report: The Police 183-86 (1967), and the studies cited therein; A. Reiss, The Police and the Public (1971); 2 A. Reiss, Studies of Crime and Law ENForcement In Major Metropolttan AREAS (1966).

48. Consider, for example, the development and use of the Law Enforcement Information Network (LEIN), described in Michigan Commission on LAW ENFORCEment and Criminal Justice, first Comprehensive Law Enforcement and Criminal Justice Plan for Michigan, app. A (1969). See also National Advisory Comimission on Criminal Justice Standards and Goals, Polige, Standard 24.1 (1973) (hereinafter NATIONAL Advisory Commisston).

49. 390 Mich. 672, 213 N.W.2d 116 (1973).

50. See, e.g., People v. Kuntze, 371 Mich. 419, 124 N.W.2d 269 (1963); People v. Zeigler, 358 Mich. 355, 100 N.W.2d 456 (1960); People v. Hutton, 50 Mich. App. 351, 213 N.W.2d 320 (1973); People v. Beauregard, 21 Mich. App. 224, 175 N.W.2d 301 (1970). Of course, a traffic stop may be challenged on the ground that it was used merely as a pretext to afford the officers an opportunity to examine the car and question the occupants, see People v. Kuntze, 371 Mich. 419, 124 N.W.2d 269, 272 (1963), but such a challenge is difficult to sustain where the traffic stop was made by a regular patrol officer and there was no irregular treatment of the driver. See Y. KAMLSAR, W. LAFAVE \& J. Israel, Modern Criminal Procedure 292 (4th ed. 1974) (collecting cases). 
mental guidelines regulating the use of stop authority, ${ }^{51}$ and as judicial decisions gradually explore the scope of that authority. ${ }^{52}$

Some Committee members argued that, even if we had reliable, current information, most of the issues treated in the ALI Code still could not be resolved by rigid standards if the Committee adhered to the "balancing" approach of Terry. The Court in Terry stressed that the reasonableness of a frisk under the fourth amendment was to be determined by balancing "the governmental interest which allegedly justifies official intrusion" against "the nature and quality of the intrusion." 53 To apply this test to investigatory stops, the Committee members contended, a case-by-case analysis is essential. The infringement of liberty imposed by the particular stop must be weighed against the strength of the evidence possessed by the officer and the purpose of his action. In evaluating the infringement of liberty, a court must consider various factors, including: (1) the length of detention; (2) the degree of coercion used in making the stop (e.g., whether the officer asked the person to "hold on for a second," or approached with gun removed and ordered the suspect to "halt"); and (3) whether the person was required to accompany the officer to another place (e.g., to "check out" an explanation). In evaluating the basis for the stop, the seriousness of the possible crime should be an important, although not the sole factor. ${ }^{54} \mathrm{~A}$ requirement that the offense be a felony would bar stops for some fairly significant misdemeanors even though the officer possesses reasonable grounds that barely fall short of probable cause. Indeed, limiting stops to suspected felons would be inconsistent with the Court's recognition in Terry of the authority to stop on the

51. Stop and frisk guidelines adopted in cities outside Michigan are cited in PLE Moder. Rules, supra note 9, at 24-25; Quinn, supra note 9, at 26 n.9. Nationar ADvisory Commission, supra note 48 , recommends adoption of such guidelines and collection of data through a "reportable incident file." See Standards 1.3, 24.2. See also Michigan Commission on Criminal. Justice, Draft Griminal Justice Goals and StanDARDS For The State of Michigan, Standards 111.1.2.2, 111.1.6.1 (1974).

52. One question of particular interest to the Committee was whether limits formulated in light of those situations requiring the most extensive stops tended to become the standard guideline for all stops. For example, where a police agency adopts a guideline like ALI CoDE, supra note 5, § 110.2(1), permitting stops for "such period as is reasonably necessary . . . but in no case more than 20 minutes," do the police tend to extend most of their stops to the 20-minute maximum? Some Committee members expressed concern that this would occur unless the permissible grounds for extending the stop were stated in much more specific terms. These members objected, for example, to a standard that authorized extension of a stop where "reasonably necessary to . . . verify ... identification" without also indicating what constituted adequate verification. See id. § $1102(1)(a)(i i)$.

53. Terry v. Ohio, 392 U.S. 1, 21, 24 (1968).

54. Cf. Brinegar v. United States, 338 U.S. 160, 180 (1949) (Jackson, J., dissenting). 
basis of suspicious street activity. When the stop is based on such activity, the officer may have the investigation of crimes of varying seriousness in mind. Thus, where a suspect is obviously keeping a house under surveillance, the officer may be concerned that the suspect intends to engage in activities ranging from theft of a bicycle to kidnapping. ${ }^{55}$

In sum, these Committee members acknowledged the relevance of the various elements noted in the ALI Code, but felt that those elements must be balanced against each other in each case. Thus, where the officer relies solely upon the observation of suspicious activity, as in Terry, only a brief stop might be appropriate. Where, on the other hand, the officer knows that an armed robbery has just been committed in the vicinity, and the stopped individual meets a general description of the criminal, the stop may be considerably longer, and some movement from the scene and even an initial show of a weapon may be appropriate. ${ }^{56}$ Similarly, even though the crime is comparatively insignificant (e.g., defacing a public sign), when the officer finds several persons at the scene and it is clear that one of them has committed the offense and the others are witnesses, a brief period of detention may be reasonable to permit the officer to obtain each person's name and to determine if there is evidence at the scene pointing to the guilt of any one person. ${ }^{b 7}$

Some members of the Committee, although agreeing that the balancing approach of Terry is inconsistent with specific legislative guidelines, nevertheless suggested that legislative limitations were necessary because the balancing approach grants the police excessive discretion. They appreciated the lack of data on current use of stop authority, but argued that the very potential for misuse was sufficient justification for adopting at least some legislative safeguards. These members were particularly concerned that investigative stops not be misused against persons whom the police have generally viewed as suspicious-for example, long-haired youths, unconventionally attired persons, and blacks found in "white areas." In response to these concerns the Committee examined various ALI Code proposals designed to prevent such abuse: (1) that stops be allowed only in the investigation of crimes involving "danger of forcible injury to persons or of appropriation or damage to prop-

\footnotetext{
55. See, e.g., People v. Hutton, 50 Mich. App. 351, 213 N.W.2d 320 (1973); People v. Rivers, 42 Mich. App. 561, 202 N.W.2d 498 (1972).

56. Cf. People v. Whalen, 390 Mich. 672, 213 N.W.2d 116 (1973).

57. Cf. People v. Parisi, 46 Mich. App. 322, 208 N.W.2d 70 (1973) (upholding auto. mobile stop for suspected curfew violation).
} 
erty,"68 thereby excluding stops in connection with many misdemeanors and narcotics offenses; (2) that stops based upon suspicious behavior be limited to situations in which it appears that the person has just committed or is about to commit a crime; ${ }^{59}$ (3) that the stop be limited to a maximum of twenty minutes; (4) that the stop be limited to detaining the person near the place where the stop is made; (5) that roadblock stops of vehicles be limited to stops of all or most vehicles; (6) that the person stopped be warned of his right to remain silent and be told that he will be released within twenty minutes unless arrested; (7) that no suspect be questioned once he indicates that he does not wish to be questioned or that he desires to consult with counsel; and (8) that a police record be made of all stops. ${ }^{\text {Bo }}$

The Committee also considered three other proposals designed to prevent abuse of stop authority. Some Committee members suggested that the potential for abuse was so great that the authority to stop on less than probable cause should be eliminated entirely. Others would have required that the stopped individual be given a "citizen's inquiry card" noting the time and date of the stop, the officer involved, and the reason for and location of the stop. ${ }^{61} \mathrm{Fi}$ nally, some members would have limited the authority to stop to cases in which the officer (i) has reasonable cause to believe a felony has been committed, (ii) has received a description of the offender (although not necessarily one that is sufficiently specific or reliable to support a probable cause arrest), and (iii) stops a person who generally fits that description. The purpose of this last proposal was to eliminate stops based upon "suspicious street behavior," as was involved in Terry, on the ground that such authority is most susceptible to abuse. A stop in the situation presented by Adams was viewed as less subject to abuse because the officer's discretion is limited by the prerequisite of a report from a third person specifying the offense involved and providing a description of the offender.

The Committee as a whole concluded that it was not prepared to support any of these proposals as a means of preventing abuse of stop authority. Some members felt that here again there was insufficient information available to provide a basis for legislation.

58. ALI CoDE, supra note 5, § 110.2(1)(a)(i), (b)(i).

59. See id. $\S 110.2(1)$ (a). A note following this section states that the provision is designed to require that the stop "take place in the res gestae of the crime-that is in the vicinity of and roughly contemporaneously with the crime." Id. at 11.

60. See id. § 110.2. 1967).

61. See, e.g., New Orleans Police Department, General Order \#32-P, § A(8) (April 7, 
While pre-Terry studies established some abuse, almost no information was available on the impact of subsequent police training on the use of stop authority in accord with Terry. The recent adoption of internal police guidelines governing stop and frisk authority was cited as evidence of potentially fruitful efforts to prevent abuse. ${ }^{62}$ Other Committee members stressed the lack of any basis for determining what kinds of restraints would prove effective in preventing abuse. ${ }^{63}$ The commentary to the ALI Code notes that the proposals advanced there are made without "any objective empirical evidence" as to the types of limits that are likely to prevent abuse. ${ }^{04}$ The Code attempts to strike "a balance between filling the need [for stop and frisk authority] and minimizing the costs and dangers," but the commentary acknowledges that the balance is struck "to a large extent on analytic and intuitive grounds." ${ }^{\circ 5}$ The Committee concluded that, given the incomplete data, greater flexibility is needed than the ALI Code would permit, and that experimentation should be left to internal police guidelines, supplemented by judicial authority to bar any pattern of patent abuse. ${ }^{66}$

\section{Nontestimonial Identification Orders}

Although the problems presented by legislative authorization of nontestimonial identification orders are similar in many respects to those presented in the stop and frisk area, the Committee found that additional considerations supported limited legislative authorization of such orders. Proposed section 22 permits the court to order a suspect to participate in specified evidence-gathering procedures (e.g., fingerprinting) that are nontestimonial in nature and therefore not contrary to the suspect's privilege against self-incrimination.7 The court may issue the order on the basis of a factual showing that would not meet the traditional probable cause standard for the is-

62. See regulations cited note 51 supra. On the capacity of police agency rulemaking to deal effectively with police abuse, see Amsterdam, The Supreme court and the Rights of Suspects in Criminal Cases, 45 N.Y.U. L. REv. 785, 812-15 (1970); Quinn, supra note 9.

63. See, e.g., the discussion in note 52 supra on the impact of imposing a "time limit" on stops. Similarly, some members were concerned that requiring recordkeeping by methods such as distribution of citizen's inquiry cards might be misused to develop lists of "suspicious persons" or "persons frequently stopped for suspicious activities."

64. ALI Cone, supra note 5, at 116.

65. Id. at 117.

66. See Williams v. Alioto, excerpted in 15 Grm. L. REP. 2187 (N.D. Cal. April 25, 1974); ABA Standards, The Urban Police Function $\$ 4.4$ (b) (Approved Draft, 1973).

67. See, e.g., Gilbert v. California, 388 U.S. 263, 266-67 (1967) (handwriting exemplars); United States v. Wade, 388 U.S. 218, 221-23 (1967) (speech samples for voice identification); Schmerber v. California, 384 U.S. 757, 760-65 (1966) (blood samples). 
suance of a warrant either to arrest the suspect or to undertake a full search of his person. Provisions similar to section 22 have been adopted in Arizona, ${ }^{68}$ North Carolina, ${ }^{68}$ and Idaho, ${ }^{70}$ and have been proposed by the American Law Institute, ${ }^{71}$ the National Conference of Commissioners on Uniform State Laws, ${ }^{72}$ and the Committee on Rules of Practice and Procedure of the Judicial Conference of the United States. ${ }^{73}$

The Committee could find little empirical data relating to the need for nontestimonial identification orders. Past case histories illustrate certain situations in which suspect participation in a nontestimonial evidence procedure ordinarily would lead directly to the identification of the offender, ${ }^{74}$ but no reliable estimate could be obtained as to how frequently such situations arise. Neither could it be determined whether nontestimonial evidence orders could be used effectively in various situations in which such evidence would be less significant in identifying the offender. ${ }^{75}$ In light of this lack of data, the Committee concluded that it should proceed cautiously. This area, however, could not appropriately be left to judicial development. Michigan courts probably would be unwilling to order suspect participation in nontestimonial identification procedures in the absence of legislative authorization. In this area, unlike the stop and frisk area, there is no established precedent of the Supreme Court or the Michigan appellate courts recognizing the validity of the nontestimonial identification order. ${ }^{76}$ Neither is there an estab-

68. ARIz. REv. STAT. ANN. \& 13-1424 (Supp. 1973).

69. N.C. GEN. STAT. § 15A-271 to -272 (effective July 1, 1975).

70. IDAнo Code § 19-625 (Supp. 1974). See also Utaf Code ANn. § 77-13-37 (Supp. 1973) (limited to lineups); CoLo. R. CrIM. P. 4l(b) (fingerprints).

71. ALI Code, supra note 5, art. 160 (Tent. Draft No. 6, 1974).

72. Uniform Rules of Criminal Procedure, Rules 434, 435 (Proposed Final Draft, 1974) [hereinafter UNIFORM RULES].

73. Federal Rules of Criminal Procedure for the United States District Courts, Rule 41.1 (Prelim. Draft), 52 F.R.D. 409, 462-67 (1971).

74. Initially police must have discovered nontestimonial evidence that will assist in establishing the offender's identity. Even then, nontestimonial evidence obtained from suspects is not fairly certain to lead to the identification of the offender unless the participating suspects include all of the persons who reasonably could have committed the offense. Situations do arise, however, in which such a complete group of suspects can be identified. Thus, access to the scene of the crime may have been so restricted or the characteristics of the offender so unique that there is a very strong likelihood that the offender is one of a limited group of persons, all of whom can be identified.

75. Consider, for example, a case in which the modus operandi of the crime generally points to several persons in the community who have committed similar crimes in the past.

76. While United States v. Dionisio, 410 U.S. 1 (1973), upheld the constitutionality of grand jury subpoenas directing individuals to furnish voice exemplars, the grand jury setting may be distinguished from the section 22 proceeding. Davis v. Mississippi, 
lished judicial practice at the lower court level. In the absence of legislation, the police officer's natural inclination might be to attempt to obtain the evidence through manipulation of other procedures rather than to present such an "unusual" request to the lower courts. Thus, police might simply arrest the suspect on the basis of doubtful "probable" cause, or arrest for some misdemeanor unrelated to the offense in question and then direct the suspect to participate in a nontestimonial evidence procedure while in custody. ${ }^{77}$ Legislation hopefully would encourage police to utilize court orders and, perhaps, avoid unnecessary arrests.

The Committee was also influenced by arguments that legislation on nontestimonial identification orders need not consider as many different factual situations as need be considered in formulating stop and frisk legislation. It was possible to concentrate upon the few key situations in which the need for such orders is most clearly estab. lished, ${ }^{78}$ and therefore to formulate a standard of probability more precise than the "reasonable suspicion" standard of Terry. Section 22(e) requires a showing of probable cause to believe that the offense was committed by "one of a grouping of not more than several persons" and that the particular suspect "falls within that group." Thus, there must be probable cause as to the total group of suspects. As to the individual suspect, probable cause is lacking only because the number of equally likely suspects is too large to present a substantial likelihood that any particular person in the group is the guilty person.

Additionally, since section 22 grants the court discretion to control the conditions under which nontestimonial evidence is obtained, there was less concern that legislative authorization would be misused, even if the legislation did not anticipate the need for certain safeguards. On the other hand, the limited area of need for nontestimonial identification orders indicates that, if future experience should show the Committee's proposal is overly restrictive, the adverse consequences will not be nearly as great as the consequences

394 U.S. 721 (1968), contains dictum that suggests a fingerprint order would be upheld, but the opinion does not directly treat that issue. With respect to other jurisdictions, see Wise v. Murphy, 275 A.2d 205 (D.C. Ct. App. 1971). See also United States v. Greene, 429 F.2d 193 (D.C. Cir. 1970).

77. See ALI CoDs, supra note 5, § 170.6, at 245-46 (Tent. Draft No. 6, 1974); UnIForm Rules, supra note 72, Commentary to Rule 436(a). The grand jury subpoena does not provide an administratively adequate alternative to section 22 , particularly in a state such as Michigan, where the availability of grand juries is limited. See note 76 supra.

78. See note 74 supra. 
that might flow from the imposition of an unnecessary limitation upon stop and frisk authority. ${ }^{79}$

\section{WARRANTLESS SEARCHES}

Notwithstanding the increased use of search warrants, the vast majority of all searches still are made without warrants. ${ }^{80}$ Nevertheless, the guidelines governing warrantless searches remain ambiguous. It was primarily with reference to warrantless searches that Justice Frankfurter noted that " $[t]$ he course of true law pertaining to searches and seizures ... has not-to put it mildly-run smooth."81 While many subsequent Supreme Court opinions have discussed warrantless searches at length, those opinions, taken as a group, still seem to fall short of the goal envisaged by Justice Frankfurter"that the law on searches and seizures by which prosecutors and trial judges are to be guided should be as clear and unconfusing as the nature of the subject matter permits." 82 Despite the apparent need for more precise guidelines, the Committee concluded that the desired clarification could not appropriately be provided by legislation.

Traditionally, legislation has played a comparatively minor role in the development of the law governing warrantless searches. The Michigan Code contains only one major provision dealing with the issue of when a search can be made without a warrant, and that provision has not been relied upon by the Michigan courts. ${ }^{83}$ Other

79. See note 34 supra.

80. See Y. Kamisar, W. LAFAve \& J. IsRaed, supra note 50, at 266. See also note 4 supra.

81. Chapman v. United States, 365 U.S. 610, 618 (1961) (concurring opinion).

82. Chapman v. United States, 365 U.S. 610, 618 (1961) (concurring opinion). The Committee's goal also was to provide some degree of guidance for peace officers. It recognized that legislation could not provide the specificity needed in police regulations. See, e.g., Project on LaW Enforgement Policy and Rulemaking, Model Rules for Law Enforcement-Warrantless Searchies of Persons and Places (1973) thereinafter ple Warrantless Searches]; TeXas Criminal Justice Counsed, Model Rules for Law ENFORGEMENT OFFICERS (1974). See also Quinn, supra note 9, at 31-35. Indeed, working rules for police officers may often require more specific guidelines than are provided even in most police regulations (e.g., in defining the scope of an inventory search at a jail, working rules probably should refer to the examination of particular items, such as wallets and cigarette packages). Nevertheless, a fairly specific legislative code, while not sufficient in itself, could provide considerable assistance to police in developing appropriate regulations and working rules.

83. Mrch. CoMp. LAWS ANN. \& 764.25 (1968) provides: “Any person making an arrest shall take from the person arrested, all offensive weapons or incriminating articles which he may have about his person and must deliver them to the sheriff of the county, chief of the police of the city or to the magistrate before whom he is taken." Although this provision applies to peace officers, People v. Henderson, $25 \mathrm{Mich}$. App. 28, 180 N.W.2d 903 (1970), appellate decisions dealing with searches incident to an 
state codes follow the same pattern; even the most recent revisions tend to treat only one type of warrantless search, the search incident to an arrest. ${ }^{84}$ The Committee, however, did not view itself as bound by the traditional role of legislation in this area. ${ }^{85}$ It considered at length the provisions of the ALI Code that describe the permissible grounds for a warrantless search, ${ }^{86}$ but decided against urging adoption of either those or similar provisions.

Any legislative guidelines for warrantless searches would, of course, have to be consistent with the decisions of the Supreme Court. Currently prevailing decisions have stressed that, "as a general rule," the Constitution requires that a search be authorized by a warrant; a warrantless search, though supported by probable cause, will be acceptable "only in exigent circumstances." sions suggest that exigent circumstances exist only when "urgent necessity"88 justifies the failure to obtain a warrant, that is, when it is not "practicable" to obtain a warrant because the delay is very likely to result in the loss or destruction of the evidence sought or may subject the officers to possible danger. ${ }^{89}$ Yet other decisions suggest that this "strict practicability" standard is not always controlling; other factors may justify a warrantless search where the delay in obtaining a warrant presents difficulties, but readily could be handled without a loss of evidence. The two primary illustrations of such "departures" from a "strict practicability" approach are Cham. bers v. Maroney $y^{00}$ and United States v. Edwards. ${ }^{01}$

arrest have rarely discussed or cited the provision. The opinions have procecded on the assumption that the officer has authority to search incident to the arrest to the extent permissible under the federal and state constitutions. See, e.g., People v. Moore, 391 Mich. 426, 216 N.W.2d 770 (1974); People v. Bohm, 49 Mich. App. 244, 212 N.W.2d 61 (1973); People v. Simmons, 49 Mich. App. 80, 211 N.W.2d 247 (1973). Cf. note 32 supra.

84. See, e.g., ILL. Rev. STAT. ch. 38, § 108-1 (1973); LA. Code CrIM. P. art. 225 (1967); Wis. STAT. ANN. \& 968.10 (1971).

85. In contrast to the position taken with respect to warrantless searches, codes of criminal procedure commonly contain provisions describing the grounds for warrantless arrests. See, e.g., MICH. CoMp. LAWS ANN. \$ 764.15 (1968). The Committee concluded that, if feasible, it would be appropriate to describe the permissible grounds for warrantless searches with at least the same specificity that the current code provides in describing grounds for warrantless arrests or for the issuance of a search warrant.

86. See ALI CoDE, supra note 5, §§ SS 230-60. See also note 104 infra.

87. Chambers v. Maroney, 399 U.S. 42, 51 (1970).

88. Williams v. United States, 401 U.S. 646, 660 n.I (1971) (Brennan, J., concurring).

89. See, e.g., Vale v. Louisiana, 399 U.S. 30, 35 (1970); Chimel v. California, 395 U.S. 752, 762-63 (1969); Davis v. Mississippi, 394 U.S. 72I, 728 (1969); Terry v. Ohio, 392 U.S. 1, 20 (1968); Schmerber v. California, 384 U.S. 757, 770 (1966).

90. 399 U.S. 42 (1970).

91. 415 U.S. 800 (1974). 
In Chambers, the Court upheld a warrantless search of an automobile conducted after its occupants had been removed from the vehicle, arrested, and taken to the police station. The majority sustained the search under the "moving vehicle" exception to the warrant requirement,, 92 presumably because the driver (if released) or his agent could demand return of the car before the police could obtain a warrant. The majority rejected the contention that, "because of the preference for a magistrate's judgment, only the immobilization of the car should be permitted until a search warrant is obtained . . . "93 It noted that "[f]or constitutional purposes," there is "no difference between ... seizing and holding a car before presenting the probable cause issue to a magistrate and . . . carrying out an immediate search without a warrant."94 In Edwards, the Court relied upon a somewhat different analysis in upholding the warrantless seizure and subsequent scientific examination of clothes taken from the defendant ten hours after his arrest. The Court noted that the search incident to an arrest had long been recognized as an exception to the warrant requirement, and that the delay in undertaking the search did not require issuance of a warrant where the defendant had remained in jail and was still subject to normal custodial restraints, including possible removal of possessions. ${ }^{95}$

92. In Carroll v. United States, 267 U.S. 132, 153 (1925), the Court noted that the fourth amendment must be construed "as recognizing a necessary difference between a search of a store, dwelling house or other structure in respect of which a proper official warrant readily may be obtained, and a search of a ship, motor boat, wagon or automobile, for contraband goods, where it is not practicable to secure a warrant because the vehicle can be quickly moved out of the locality or jurisdiction in which the warrant must be sought." In Carroll, the driver of the vehicle had not been placed under arrest, and there was considerable doubt prior to Chambers as to whether Carroll justified a warrantless search of a car after the arrest of the driver. Compare Chambers with Ramon v. Cupp, 423 F.2d 248, 249 (9th Cir. 1970), and Heffley v. Hocker, 420 F.2d 881, 885 (9th Cir. 1969).

Subsequent to Chambers the Supreme Court upheld two other post-arrest searches of automobiles. See Cardwell v. Lewis, 417 U.S. 583 (1974) (upholding warrantless scizure and impoundment of arrested person's automobile, found in parking lot, and subsequent scientific examination of paint chips found on exterior of car); Cady v. Dombrowski, 413 U.S. 433 (1973) (upholding warrantless "custodial search" of automobile for weapon reasonably believed to be located there; car had been towed to service station after driver's arrest and hospitalization). But see Coolidge v. New Hampshire, 403 U.S. 443 (1971), discussed in note 96 infra.

93. 399 U.S. at 51.

94. 399 U.S. at 52.

95. Although Edwards and Chambers relied upon different "exigent circumstances," the two decisions are similar in several respects. In both cases the majority stressed that, since a warrantless search could have been made at the time of the arrest, the delay in conducting the search should not necessarily require the acquisition of a warrant. See 415 U.S. at $807 ; 399$ U.S. at 52 . In both cases the majority relied upon a debatable application of a well-established exception to the warrant requirement, rather than upon creation of a totally new exception. Also, both cases recognized that 
Although Chambers and Edwards illustrate that the existence of reasonable opportunity to obtain a warrant does not necessarily invalidate a warrantless search, they do not go so far as to suggest that warrants will never be required for any search of an automobile or of a person held in custody. ${ }^{.6}$ Moreover, considerable doubt exists whether factors similar to those noted in Chambers and Edwards would justify warrantless searches of other areas protected by the fourth amendment. ${ }^{97}$ Accordingly, the Committee concluded that any legislation authorizing warrantless searches would have to be largely consistent with a strict practicability approach if its constitutionality was to be assured. The Committee was unwilling to propose such legislation, however, for several reasons.

Some Committee members simply opposed the strict practicability approach. Though acknowledging the desirability of obtaining a warrant, they did not believe that a search should be invalidated,

"[t]he prevailing rule under the Fourth Amendment [is] that searches . . . may not be made without a warrant." 415 U.S. at $802 ; 399$ U.S. at 51 . Edwards, however, also cited with approval language to the effect that the "test" under the fourth amendment is " 'not whether it [is] reasonable to procure a search warrant, but whether the search itself [is] reasonable." " 415 U.S. at 806-07, quoting Cooper v. California, 386 U.S. 58, 62 (1967), qroting United States v. Rosenberg, 339 U.S. 56, 66 (1950).

Arguably, both Edwards and Chambers also presented the issue of weighing the restraint imposed by immobilizing the defendant's property against the "preference for a magistrate's judgment." If Edwards had been released on bail before a warrant could be obtained, the police presumably would have had to "immobilize" the clothes if they desired to prevent Edwards from taking and destroying them. Finally, in both Edwards and Chambers Justice White wrote the majority opinion. On the other hand, Justices Brennan, Douglas, Marshall, and Stewart, who dissented in Edwards, joined the majority in Chambers.

96. The Court specifically noted in Chambers that "[n]either [Carroll v. United States, 267 U.S. 132 (1925); see note 92 supra] nor other cases in this Court require or suggest that in every conceivable circumstance the search of an auto even with probable cause may be made without the extra protection for privacy that a warrant affords." 399 U.S. at 50. Subsequently, in Coolidge v. New Hampshire, 403 U.S. 443 (1971), the plurality opinion held invalid a warrantless search of an automobile where, inter alia, "the police had known for some time [prior to the search] of the probable role of the ... car in the crime," and "[t]here was no way in which [the defendant] could conceivably have gained access to the automobile after the police arrived on his property." 403 U.S. at 460 . Chambers was distinguished as a case that "held only that, where the police may stop and search an automobile under Carroll, they may also seize it and search it later at the police station." 403 U.S. at 463.

Michigan cases have also required warrant authorization of a vehicle search under certain circumstances. See Pcople v. White, 392 Mich. 404, 221 N.W.2d 357 (1974); People v. Weaver, 35 Mich. App. 504, 192 N.W.2d 572 (1971).

With respect to the possible need for a warrant to conduct an intensive search of the body of the person, see text at notes 198-201 infra.

97. See, e.g., Vale v. Louisiana, 399 U.S. 30 (1970); United States v. Van Leeuwen, 397 U.S. 279 (1970); Chimel v. California, 395 U.S. 752 (1969). These cases arguably differ considerably from chambers in their view of the desirability, from a constitutional perspective, of immobilizing property so that a search warrant may be sought. See LaFave, Warrantless Searches and the Supreme Court: Further Ventures into the "Quagmire", 8 CrIM. L. Bur.. 9, 27 (1972); note 101 infra. 
and evidence excluded, simply because the officer had the opportunity to obtain a warrant but failed to do so. They would judge the "reasonableness" of a search by considering not only the failure to obtain a warrant, but also the strength of the probable cause possessed by the officer and the extent of the search. Thus, it was suggested, where a locked suitcase, reasonably believed to contain contraband, is found in the possession of an arrested person, it might be reasonable for the officer to open the suitcase immediately, although it no longer is within the arrested person's immediate control and easily could be retained by the officer for the period necessary to obtain a warrant..$^{98}$ Along the same lines, it was argued that when an officer has arrested a person in a motel room for the attempted sale of narcotics, and there is probable cause to believe that more narcotics are located in the room, the officer should not be barred from proceeding without a warrant to examine certain portions of the room, such as the toilet flush tank, that are not open to plain view but also are not traditional storage areas for private possessions.99 While some courts would view such searches as unconstitutional under current precedent, others might uphold the searches under a narrow reading of that precedent. If the Committee, however, drafted a warrantless search provision based upon a strict practicability approach, the searches in both illustrations would be invalid. ${ }^{100}$

Other Committee members favored a strict practicability approach but felt that that approach could be imposed by legislation only after machinery was established that would permit prompt acquisition of search warrants. They believed that the state could not reasonably bear the risk of losing evidence due to the lengthy period that might be needed to obtain a warrant. Moreover, if the police were allowed to protect against that risk by "securing" the place to be searched while a warrant was obtained, innocent individuals conceivably could be denied access to the place for several hours. ${ }^{101}$

98. Compare United States v. Robbins, 424 F.2d 57 (6th Cir.), cert. denied, 402 U.S. 985 (1970), with Faubion v. United States, 424 F.2d 437 (10th Cir. 1970).

99. Cf. United States v. Patterson, 447 F.2d 424 (10th Cir.), cert. denied, 404 U.S. 1064 (1971); People v. Simmons, 49 Mich. App. 80, 211 N.W.2d 247 (1973); State v. Erwin, 473 S.W.2d 394 (Mo. 1971).

100. See, e.g., ALI CODE, supra note 5, § SS 230.5, which permits a warrantless search of premises incident to an arrest only if (1) "the arrested individual is in or on [the] premises," and (2) the officer has reason to believe that the premises contain evidence connected with the offense that is "likely to be removed or destroyed before a search warrant can be obtained and served ...." See also id. § SS 230.3.

101. See Griswold, Criminal Procedure, 1969-Is It a Means or an End?, 29 MD. L. REv. 307, 317 (1969):

Does the police officer have any power to maintain the status quo while he, or a colleague of his, is taking the time necessary to ... obtai[n] the search warrant if 
These members hoped that the various Committee proposals designed to promote prompt acquisition of warrants would be effective, ${ }^{102}$ but were unwilling to impose a strict practicability standard until those provisions had been proved in practice.

Still other Committee members favored adoption of a strict practicability standard only if it were buttressed by detailed guidelines as to those "exigent circumstances" that would justify warrantless searches. They argued that there would be little value in merely repeating the strict practicability standard stated in Supreme Court opinions. ${ }^{103}$ As those opinions indicate, however, a key to the application of the strict practicability standard lies in defining the permissible scope of those warrantless searches that are automatically accepted under that standard (e.g., the search incident to arrest). Legislation could make a substantial contribution only if it provided specific standards defining the permissible scope of such searches. ${ }^{104}$

it is issued, and then brin[g] it to the place where the arrest was made. It seems inevitable that a minimum of several hours will be required for this process, at the very best. Unless there is some kind of a power to prevent removal of material from the premises, or destruction of material during this time, the search warrant will almost inevitably be fruitless. . . . May they guard the premises, and prevent egress and entry, and action within the premises, while the search warrant is being obtained? We do not know. There may well be room here, though, for a balance in determining the applicability of the fourth amendment.

See also Note, Police Practices and the Threatened Destruction of Tangible Evidence, 84 HARv. L. REv. 1465 (1971); note 97 supra. PLE WARRANTLEss SEARches, supra note 82 , provides in Rule $303[\mathrm{c}]$ :

If an officer reasonably believes that other persons on the premises at the time of the arrest - or who later arrive at the premises and have a right to enter-might conceal, remove or destroy seizable items, he shall explain that a search warrant is being obtained. He shall also ask such persons to leave the premises [for up to two hours] or to permit an officer to remain within the premises [for up to two hours] while the warrant is obtained. If neither request is complied with, or if diligent police efforts fail to procure a warrant within two hours, the officer may then search for the seizable items [for not longer than twenty minutes]. [Emphasis original.]

102. See text at notes $141-63$ infra on the required availability of magistrates and the authorization of telephonic search warrant applications.

103. See notes 88-89 supra.

104. See, e.g., ALI CoDE, supra note 5, \& SS 230.5. The ALI Code contains provisions on the following warrantless searches: searches incident to an arrest, searches by consent, vehicle searches, searches of open lands, emergency searches, and border searches. Section SS 230.5 , governing searches of premises incident to an arrest, illustrates one of the more detailed provisions. That section provides:

(1) Permissible Circumstances. If at the time of the arrest (a) the arrested individual is in or on premises all or part of which he is apparently entitled to occupy, and (b) in view of the circumstances the officer has reason to believe that such premises or part thereof contains things which are (i) subject to seizure under Section 210.3, (ii) connected with the offense for which the arrest is made, and (iii) likely to be removed or destroyed before a search warrant can be obtained and served, the arresting officer may search such premises or part thereof for such things, and seize any things subject to seizure under Section SS 210.3 and discovered in the course of the search. 
These members contended, for example, that little would be gained by merely codifying the ruling in Ghimel $v$. California ${ }^{105}$ that an arrested person and the area within his control may be searched contemporaneously with the arrest to effectuate the arrest with safety and prevent the destruction of evidence. ${ }^{108}$ Meaningful legislation should go beyond Chimel by defining the area "within the immediate control" of the arrested person. In particular, must the area be determined in light of the capacity of the particular person at the time of the search (e.g., taking into consideration the fact that he was handcuffed, or the number of officers present), or is it to be measured by a general assessment of the "lunging capacity" of most persons? ${ }^{107}$ Similarly, once the person is in custody, what standards should be employed to limit the misuse of various "excuses" for entering other parts of the premises and thereby expanding the area of the search? May the officer on the basis of "mere suspicion" examine the entire house to determine if any other offenders or persons who might destroy evidence are present? ${ }^{108}$ Also, if the officer comes upon persons who might destroy evidence hidden in the house, but who are not subject to arrest, may he direct them to leave while he obtains a warrant? ${ }^{109}$ Similar questions would have to be answered in defining the scope of jail-inventory searches and

(2) Time of Search. Search of premises pursuant to Subsection (1) shall only be made contemporaneously with the arrest, and search of building interiors shall only be made consequent upon an entry into the building made in order to effect an arrest therein. In determining the necessity for and scope of the search to be undertaken, the officer shall take into account, among other things, the nature of the offense for which the arrest is made, the behavior of the individual arrested and others on the premises, the size and other characteristics of the things to be searched for, and whether or not any such things are observed while making the arrest.

105. 395 U.S. 752 (1969).

106. See, e.g., Kan. STAT. ANN. § 22-2501 (Supp. 1973). Cf. ALI CodE, supra note 5, § SS 230.3(1): "An officer making an arrest on a charge other than as described in Section SS 230.2 [excluding minor offenses] and the authorized officials at the police station or other police building to which the arrested individual is brought, may conduct a search of the arrested individual's garments and personal effects ready to hand, the surface of his body, and the area within his immediate control."

107. See Bailey v. United States, 279 F.2d 508 (D.C. Cir. 1971); Scott v. State, 7 Md. App. 505, 508-09, 256 A.2d 384, 387-89 (1969); Note, Warrantless Searches in Light of Chimel: A Return to the Original Understanding, 11 ARIz. L. Rev. 457, 480 (1969).

108. See People v. Schrantz, 50 Mich. App. 227, 213 N.W.2d 257 (1973); PLE WARRANTLESS SEARches, supra note 82, Rule 303(a): "If an officer has probable cause to believe that seizable items are on the premises where an arrest has just been made, he may make a prompt general inspection to determine whether there are persons present who are likely to remove or destroy the items while a search warrant is being obtained. Under no circumstances should this inspection include a search for seizable items." (Footnote omitted.)

109. See Shuey v. Superior Court, 30 Cal. App. 3d 535, 106 Cal. Rptr. 452 (1973); note 101 supra. Cf. People v. Carter, 387 Mich. 397, 411-12, 197 N.W.2d 57, 63-64 (1972). 
warrantless searches of automobiles. ${ }^{110}$ The result, it was suggested, would be a series of provisions considerably more extensive than even the current statutes regulating police authority to arrest.111 Several Committee members, although in favor of a strict practicability approach, agreed that such a departure from the format of the current code would best be initiated in an area in which there was more substantial agreement as to basic principles. ${ }^{112}$

In light of the determination not to propose specific guidelines on warrantless searches, the Committee's inclusion of sections 16, 17, and 18 requires some explanation. These provisions refer to three types of constitutionally acceptable warrantless searches-the search incident to an arrest, the inventory search for custodial purposes, and the warrantless search justified by other "exigent circumstances." While these three "exceptions" to the warrant requirement are given formal recognition in sections 16 through 18 , no effort is made to provide guidelines for their application. ${ }^{113}$ Indeed, the listing of

110. A complete provision on searches incident to an arrest also requires consideration of the appropriate use of arrest authority. For example, should a search be permitted incident to an "arrest" where the officer stops a person on the basis of probable cause but determines that the individual is one who can appropriately be released upon issuance of a citation, rather than taken to the station? Several cases, e.g., Gustafson v. Florida, 414 U.S. 260 (1973); United States v. Robinson, 414 U.S. 218 (1973); People v. Moore, 391 Mich. 426, 216 N.W.2d 770 (1974), suggest that traditional authority to conduct a full search incident to an arrest may be limited to "custodial arrests" (arrests in which the person is taken to the station). See also Cupp v. Murphy, 412 U.S. 291, 296 (1973); People v. Gonzales, 356 Mich. 247, 97 N.W.2d 16 (1959). That position, however, may significantly undermine the legislative trend toward encouraging the use of citations in lieu of arrests. See ABA Standards, Pre-Trial Reuease \$ 2.3 (Approved Draft, 1968). Jurisdictions encouraging expanded use of citations generally have granted officers broad discretion (on nontraffic offenses) in determining whether to take the person into custody or issue a citation. See, e.g., KAN. STAT. ANN. \& 22-2408 (Supp. 1973); MicH. CoMP. LAws ANN. § 764.9c (Supp. 1974-1975); UNIFORM RULEs, supra note 72, Rules 211, 221. Compare Mrch. Comp. Laws ANN. \$§ 257.727-.728 (Supp. 1974-1975). If officers are not permitted to search a detained person before they have decided whether to take him to the station, they may simply ignore the possibility of release on citation. See ABA STANDARDS, supra, at 38. While Terry v. Ohio, 392 U.S. 1 (1968), provides authority to frisk, officers may feel that the Terry requirement of "suspicious circumstances" does not offer sufficient protection. See Brief for Americans for Effective Law Enforcement as Amicus Curiae, United States v. Robinson, 414 U.S. 218 (1973).

Arguably, where persons are stopped for a crime other than a possible traffic offense, they expect to be taken to the station and, if armed or carrying contraband, they will act accordingly; the police therefore should be given full search authority while the officer is deciding whether to make a "full custody arrest" or release on citation. Cf. Cupp v. Murphy, 412 U.S. 291, 296 (1973). But cf. ALI CODE, supra note 5, \& SS 230.3.

111. See Mrch. Comp. LAws ANN. \$§ 764.1-.28 (1968).

112. It was also suggested that if the provisions designed to facilitate prompt acquisition of search warrants proved effective, the courts might apply the strict practicability approach more rigidly and thereby provide a better basis for answering some of the questions noted above. See also Nakell, Proposed Revisions of North Carolina's Search and Seizure Law, 52 N.C. L. REv. 277, 311 (1973).

113. The one exception is section 16[4], which governs searches incident to an arrest 
these exceptions is not intended to be exclusive, although "exigent circumstances" is a sufficiently broad phrase to encompass all constitutionally acceptable justifications for warrantless searches except for consent. ${ }^{114}$ The description of these exceptions serves only as an introduction to the subsequent provisions in sections 16 through 18 governing the execution of warrantless searches. The manner of executing searches is a traditional area of legislative coverage, although here too provisions governing searches with warrants have tended to be more extensive than provisions governing searches without warrants. For reasons discussed in part IV, the Committee viewed the execution of searches as an area in which it could make a major contribution within the framework of current constitutional guidelines. The three types of warrantless searches are treated separately only because they present somewhat different problems in determining appropriate execution. The initial description of each type is phrased so that it should neither limit nor expand the authority to conduct the particular search as developed in judicial decisions.

\section{Facilitating the Use of Search Warrants}

Although the Committee decided against proposing legislation that would require search warrants whenever practicable, it decided that the current code should be revised so as to encourage police use of search warrants. Greater use of search warrants was favored both by those members who supported a strict practicability requirement, but who felt it could not appropriately be imposed by legislation at this time, and by those who opposed a strict practicability requirement. While the latter group resisted automatic invalidation of a search solely because an officer failed to obtain a warrant, they favored adoption of measures designed to encourage the use of warrants as a matter of good police practice..$^{115}$

by a private person. The Committee concluded that, in light of the limited enforcement responsibilities and lesser expertise of the private person, both the search and the seizure incidental thereto could appropriately be restricted to obtaining weapons and evidence of the offense for which the arrest was made. Compare United States v. Robinson, 414 U.S. 218 (1973).

114. A special provision was not included on search by consent because the standards for search execution set forth in sections 16-18 may depend upon the scope of the consent in the particular case. See, e.g., People v. Chism, 390 Mich. 104, 211 N.W.2d 193 (1973); People v. Kaigler, 368 Mich. 281, 118 N.W.2d 406 (1962). However, the sections relating to receipts and disposition of property apply to all seized property, including that obtained during a search by consent. Cf. ALI CODE, supra note 5 , § SS 280.2.

115. See Michigan Commission on CRnminal Justice, supra note 51, at 111.1.6.1, recommending that "[s]earches ... be conducted through the use of a warrant whenever possible." 
Support for encouraging the use of search warrants was based on several grounds. Most importantly, the warrant application process provides significant protection against unconstitutional searches. The Supreme Court has frequently stressed the importance of requiring "that the deliberate, impartial judgment of a judicial officer ... be interposed between the citizen and the police."116 This emphasis upon the "interposition" of the "neutral magistrate" has been criticized by various commentators as based more upon "myth than fact."117 In practice, it has been argued, warrants are frequently issued "by a minor magistrate who has little means or inclination to look behind the police application."118 While that description may be accurate as applied to other jurisdictions, there is no basis for assuming that it reflects current Michigan practice. Search warrants ordinarily have been issued by judges of a district court, municipal court, or Recorder's Court. These judges are all lawyers, and sit on courts having substantial jurisdiction in criminal cases. They can hardly be characterized as "minor magistrates." The experience of Committee members indicates that the judges recognize that a successful search is likely to be challenged by a motion to suppress, and that they accordingly exercise considerable care in issuing a warrant. Studies indicating that arrest warrants have been issued in a perfunctory manner do not support a similar conclusion with respect to search warrants. ${ }^{119}$ Most arrest warrants in Michigan are not issued before a suspect is arrested, but are issued as a preliminary step to presenting an arrested person before the magistrate for his initial appearance. The function of the warrant determination at this point is quite different from that of a search warrant determination, ${ }^{120}$ and the studies have acknowledged that most magistrates,

116. Wong Sun v. United States, 371 U.S. 471, $481-82$ (1963).

117. See LaFave, supra note 97 , at 27 , and articles cited therein.

118. ALI CoDE, supra note 5, Commentary to § SS 280.4, at 187.

119. Most of the commentators questioning the significance attached to the magistrate's participation in the search warrant process have relied upon studies relating to the issuance of arrest warrants. See, for example, the frequently cited article by Miller \& Tiffany, Prosecutor Dominance of the Warrant Decision: A Study of Current Practices, 1964 WASH. U. L.Q. 1, 4-5 (describing Recorder's Court practice as observed during 1956-1957).

120. Where the arrest already has been made, the task before the court is not preventing a fourth amendment violation, but determining whether a violation has occurred. Since the prosecutor, in approving the warrant application, has already reviewed the evidence and concluded that it is sufficient to support a prosecution, the magistrate may assume that probable cause most likely exists. Moreover, at least in felony cases, the decision on the arrest warrant application is not the only point at which a probable cause determination will be made. The same issue will be raised again at the preliminary hearing. In the meantime the individual may be immediately relieved of the initial consequence of his arrest by release on bail. While the Committee 
even before Supreme Court decisions required more substantial warrant applications, ${ }^{121}$ took considerably greater care in reviewing search warrant applications..$^{122}$

The review of a magistrate is not the only safeguard presented by the warrant application process. Although it is not legally required, applications for warrants are often reviewed by a member of the prosecutor's staff or a senior police official before being presented to a magistrate. As in the case of arrest warrants, this review can be a very effective screening device. Also, the warrant process, combined with the deterrent function of the exclusionary rule, arguably encourages more careful screening by the executing officer himself, apart from the role played by the magistrate and prosecutor. The officer who obtains a warrant recognizes that, on any subsequent suppression motion, probable cause must be established on the basis of the information he has included in his application. Unlike the warrantless search situation, there is no opportunity for

proposal on arrest requires a more extensive review of the warrant application, it is understandable why a practice of perfunctory examination may have developed in the past. See People v. Burrill, 391 Mich. 124, 214 N.W.2d 823 (1974).

121. See, e.g., Spinelli v. United States, 393 U.S. 410 (1969).

122. Consider, for example, two of the reports based upon the ABA Foundation Studies of 1956-1957, which included Michigan as one of the three states studied. In I. Tiffany, D. MaIntyre \& D. Rotenberg, Detection of Crime 119-20 (1967), the authors, although concluding that the judiciary "does not always take seriously its commitment to make a 'neutral and detached' decision," also acknowledge:

Generally magistrates give more attention to requests for search warrants than they do to requests for arrest warrants, which are often signed by the judicial officer without reading them or are signed by the judge's clerk. With rare exceptions, magistrates do read and carefully consider the evidence presented by law enforcement officers requesting a search warrant, and they frequently require the prosecuting attorney to endorse the affidavit and recommend the issuance of the search warrant, a practice often used also in arrest warrant situations. But in the search warrant case the magistrate often also reviews the evidence himself rather than relying totally on the police and prosecutor as he does in the arrest warrant case. [Footnote omitted.]

Similarly, LaFave \&: Remington, Controlling the Police: The Judge's Role in Making and Reviewing Law Enforcement Decisions, 63 Micr. L. REv. 987, 993 (1965), note: "As a general proposition, there is greater judicial concern over the issuance of search warrants than over the issuance of arrest warrants. . . . Although most judges view the issuance of a search warrant as an important responsibility, this is not true in all jurisdictions." (Emphasis added.)

While the authors of Detection of Crime, supra, suggest that this "marked difference in judicial attitude toward search and arrest warrants seems to result from habit rather than from any deliberate policy judgment," the explanation probably lies in the difference in judicial function as explained in note 120 supra. The difference may also be explained, in part, by the belief that officers are more familiar with the requirements for a valid arrest than for a valid search warrant. Both determinations require an understanding of the nature of probable cause, but in the search situation the issue may be more complicated because of the variable scope of the search (particularly where a residence is involved) and the range of items that may be subject to seizure. See Katz v. United States, 389 U.S. 347,358 (1967). 
an " 'after-the-event justification for the . . search . . . subtly influenced by the familiar shortcomings of hindsight judgment." "123

Some Committee members argued that, aside from protecting constitutional rights, a code revision facilitating the use of warrants is needed to permit the police to avoid potential constitutional diffculties. They noted that whether decisions like Chimel v. California ${ }^{124}$ and Coolidge v. New Hampshire ${ }^{125}$ were based on a correct or incorrect assumption as to the value of the warrant process, those decisions established the prevailing constitutional standard, and state law should not place unnecessary obstacles in the path of officers seeking to comply with that standard.

Several members also argued that the prosecution should be given full opportunity to gain the legal and practical advantages that attach to the use of warrants. Where a search has been conducted pursuant to a warrant, the Supreme Court has indicated that greater leeway may be given to the prosecution in determining whether probable cause existed. ${ }^{126}$ Similarly, a hearing on a suppression motion ordinarily will be more narrowly confined, and hence less time-consuming, when the challenge is to a search based upon a warrant. ${ }^{127}$ Where the search was pursuant to a warrant, the traditional view, which Michigan courts apparently follow, limits the probable cause determination at the suppression hearing to consideration of the facts alleged in the warrant application; the defendant may not introduce evidence challenging the truthfulness of

123. Katz v. United States, 389 U.S. 347,358 (1967), quoting Beck v. Ohio, 379 U.S. 89, 96 (1964).

124. 395 U.S. 752 (1969).

125. 403 U.S. 443 (1971). See note 96 supra.

126. In United States v. Ventresca, 380 U.S. 102, 106-07 (1965), the Court stressed the "preference accorded police action taken under a warrant as against searches and seizures without one," and noted "that in a doubtful or marginal case, a search under a warrant may be sustainable where without one it would fall." See also People v. White, 392 Mich. 404, 420, 221 N.W.2d 357, 364 (1974): "The judicial preference for searches conducted under the authority of a search warrant should be expressed not only in terms of the narrowly drawn exceptions to the warrant requirement but also in terms of a more stringent standard of review applied to all aspects of warrantless searches."

127. In L. Tiffany, D. MaInTyRe \& D. Rotenderg, supra note 122 , at 159 , the authors note that the "police are likely to rely on the consent search to save the time and avoid the difficulty involved in going through the rather elaborate procedure required to obtain a search warrant." As developed in the text at notes 141-206 infra, the Committee proposals seek to simplify that procedure, but even under current procedures the short-cut of "consent" may often prove in the long run to be more time-consuming than obtaining a warrant. A motion to suppress challenging alleged consent typically will require extensive testimony by all officers present, the defendant, and any bystanders, whereas the motion challenging a search warrant will rarely require the testimony of persons other than the officer who submitted the affidavit. 
these facts. ${ }^{128}$ Moreover, even if the Michigan courts follow the trend toward permitting a challenge as to the truthfulness of the applicant's allegation that he obtained certain information from an informant, ${ }^{129}$ the initial showing needed to gain an evidentiary hearing on that issue is not likely to be met in many cases. ${ }^{130}$ Finally, use of search warrants might present practical advantages in terms of citizen response. Experience suggests that, at least with respect to the search of a building, people often expect the police to have a warrant and are more likely to cooperate when they see that the police do have the authorization of a magistrate. ${ }^{131}$

\section{A. Safeguards Versus Facilitation}

Commentators have suggested that there is "an inherent and basically insoluble inconsistency between improvement of the warrant as a safeguard against abuse, and encouragement of its use."132 They note that "[a]lmost every effort to 'tighten' the warrant procedure, and give meaning to the 'neutral magistrate's' scrutiny of the application, is bound to make it more difficult and time-consuming for the police officer to get a warrant, and stimulate his resort to a warrantless basis for the search."133 While the revision of search warrant procedures does pose somewhat of a dilemma in this regard, many areas exist in which the use of search warrants could be encouraged without undermining the role of the magistrate. Similarly, additional safeguards could be added while still providing a comparatively swift and simple procedure for obtaining warrants.

The Committee started from the premise that current procedure provides fairly strong support for the exercise of independent judgment by the magistrate. Nevertheless, several safeguards were either added or clarified to strengthen the magistrate's position. ${ }^{134}$ First, some effort was made to inhibit "judge shopping."135 Under current

128. See People v. Kerwin, 234 Mich. 686, 209 N.W. 157 (1926).

129. See Nakell, supra note 112, at 295 nn.79, 80 (collecting cases).

130. See United States v. Halsey, 257 F. Supp. 1002 (S.D.N.Y. 1966).

131. See PLE WARRANTLESS SEARches, supra note 82 , at 29 . The commentary to the Model Rules offers as an additional advantage of a search warrant that it "decrease[s]" the "possibility of civil liability in the event of a mistake . . . ." Id.

132. ALI CoDE, supra note 5, at 171 .

133. $I d$.

134. As discussed in the Committee Report (to be published in 1975 by the State Bar of Michigan), some of the provisions mentioned below clearly reflect current practice and may be required by current law. Others reflect the practice in at least some parts of the state, but are not required by statute.

135. The Committee's recommendations were not based upon any empirical data suggesting that "judge shopping" is a significant problem in Michigan. The Committee simply recognized that the potential for "judge shopping" generally is a primary point 
practice, a particular magistrate in each district is designated to consider warrant applications. Police ordinarily will present to the designated magistrate any applications made during normal "business hours," but they usually have greater flexibility during evening hours, when the designated magistrate can often be bypassed as not readily available. Section 3 will ensure that more designated magistrates will remain available during evening hours. ${ }^{138}$ Section 2, while not restricting warrant authority to designated magistrates, does create a presumption in favor of those magistrates by emphasizing the discretion of other magistrates to refuse to consider applications unless the applicant shows that the designated magistrate is not available. Persistent attempts by the police to bypass an available designated magistrate would be a matter of public record and subject to the administrative authority of the Circuit Court.

"Judge shopping" is also restricted by the provision on repeat applications (section 7[2]). When a magistrate denies an application, subsequent applications on the same matter must be brought back to him, and, if he is unavailable, his replacement must be informed that the prior application was denied.

Section 7, governing consideration of warrant applications, strengthens the magistrate's role by requiring that he examine the applicant. While the examination admittedly can be perfunctory, the requirement emphasizes that the magistrate need not automatically accept the applicant's credibility. Section 7 also gives the magistrate discretion to examine other persons believed to possess relevant information, and the magistrate has the authority to insist upon questioning the source of that information. Section 7 also seeks to ensure that the ordinarily unrecorded examination is not used to undermine effective review of the magistrate's issuance of the war-

of criticism of current procedures. See L. TIFfanY, D. McInTYRe \& D. Rotenberg, supra note 122, at 119-20; Schwartz, The Legitimation of Electronic Eavesdropping: The Politics of "Law and Order", 67 Mrch. L. REv. 455, 483 (1969). In light of such criticism, there is value in restricting that potential (even if it is not currently used) -provided, of course, that any restriction is administratively practicable. The Committee concluded that a provision limiting authority to issue warrants to a single magistrate in each district would be far too inflexible, see text at notes 144-46 infra, but that a presumption against bypassing designated magistrates could be established without creating significant administrative problems or denying the flexibility needed in emergencies.

136. Where the judicial district encompasses the entire county (and in Detroit's Recorder's Court), a locally designated magistrate should always be available, since section 3 requires that at least one judge in each county (and in Recorder's Court) bc available at all times. For reasons discussed in note 143 infra, the Committee concluded that it could not justifiably require that a magistrate be continuously available in each district, ás opposed to each county. 
rant. ${ }^{137}$ The finding of probable cause must be supported solely by information contained in the affidavits; the prosecution may not support the magistrate's finding on the basis of information developed in the examination unless that information subsequently was added to the affidavit.

The reporting provision (section 14) further implements the magistrate's authority by giving him more complete information about the use of the warrants he has issued. This provision requires that a return of the warrant be made, not only when the search is executed and property seized as is currently required, ${ }^{138}$ but also when the search is executed without the seizure of property, and when the search is never executed (with the reasons therefor noted in the return). The Committee believed that compliance with the reporting and examination requirements will not be overly burdensome when viewed in light of other provisions designed to facilitate the use of warrants. Moreover, the examination requirement was viewed as essential to preserve the legal advantages ${ }^{139}$ that flow from use of the warrant process. ${ }^{140}$

\section{B. Facilitating the Warrant Application}

While the addition of the safeguards noted above is a significant feature of the proposed search warrant provisions, the thrust of the proposed changes is toward facilitating the use of search warrants. The Committee sought to encourage the use of warrants through: (1) providing for a more swift and simple application process by

137. Magistrates in many judicial districts lack facilities to make a verbatim recording of an examination. The Committee considered permitting the magistrate to make a written summary, but concluded that it would be equally convenient to amend the affidavit to include any significant information developed in the examination. On the constitutionality of using unrecorded oral testimony to supplement a deficient affidavit, see the cases collected in W. RINGLE, SEARCHES AND SEIzURES, ARRESTS, AND CoNfEsstons \& 171.09 (Supp. 1974). While several lower courts have upheld that practice, Justices Brennan and Marshall, dissenting from a denial of certiorari in Christofferson v. Washington, 393 U.S. 1090 (1969), expressed significant doubt as to its constitutionality.

138. See Mich. Comp. Laws Ann. § 780.655 (1968).

139. See text at notes 127-30 supra.

140. This is not to suggest that the examination requirement is constitutionally compelled. It might be constitutionally acceptable to follow a procedure similar to that cmployed in some states for arrest warrants-the application is sworn to before a clerk, the clerk then presents it to the magistrate without the applicant being present, and the magistrate may either issue the warrant without examining the applicant or may request that the applicant be presented. Cf. Shadwick v. City of Tampa, 407 U.S. 345 (1972). It would be far more difficult, however, to justify restricting. the defendant's ability to challenge the affidavit allegations in a subsequent suppression hearing, see text at notes 127-30 supra, when the magistrate has not examined the applicant prior to issuing the warrant. 
requiring the prompt availability of a magistrate, permitting telephonic search warrant applications, and clarifying the requisite contents of the application; (2) expanding the types of searches that may be authorized so as to permit warrant use in conjunction with all types of constitutionally permissible searches; (3) largely equalizing search execution requirements so that officers executing a search warrant do not bear substantial burdens that are not imposed upon officers engaged in warrantless searches.

\section{Availability of Magistrates}

The most frequent police objection to the use of search warrants is that the application process is too time-consuming.141 $\mathrm{A}$ major factor contributing to delay in obtaining a search warrant is the unavailability of magistrates, particularly after normal courthouse business hours. When an officer learns of criminal activity currently in process within a building, he usually will go immediately to the scene of the crime and arrest the persons involved. Similarly, when an officer receives information that establishes probable cause to believe that a person has committed a crime, he will often go directly to that person's residence to arrest him. Arrests in both instances frequently occur during evening hours. ${ }^{142}$ After making an evening arrest, the officer may find that he needs a warrant to search the premises as a follow-up to the arrest. He may have had no prior indication that a search would be needed, but matter found in plain view or on the person of the arrestee may have provided probable cause for a further search. In other situations the officer may have anticipated the need for a search but decided that his first obligation was to make an immediate arrest. (This is particularly likely where the criminal activity-for example, distribution of narcotics-is currently in progress.) In either situation there usually is a need to obtain a search warrant promptly, and the first obstacle is finding an available magistrate. Section 3 seeks to meet this problem by requiring that at least one magistrate in each county be "on call" at all times. With the use of paging devices, a magistrate should ordinarily be available within a short period of time-particularly where the telephonic search warrant application is utilized. ${ }^{143}$

141. See, e.g., L. TIFFANY, D. MaINTYRE \& D. ROTENBerg, supra note 122 , at 105 , $114-15,159$.

142. Even when the offense is committed during the day, certain sources of information furnishing probable cause, such as informants, often are most readily available after normal working hours.

143. Section 3 applies to each county rather than to each judicial district. Some Committee members thought it would be desirable to have a magistrate in each 
Section 2 supplements section 3 by permitting any magistrate within the state to issue a warrant in any case. At the same time, to inhibit judge-shopping, it grants the judge discretion to refuse to consider an application for a search unrelated to his district unless the applicant has shown that all of the judges of the related district are unavailable. The Committee rejected an alternative proposal that would have permitted a judge to issue warrants only to conduct searches within his district (and possibly neighboring districts when it was shown that all of the judges of the neighboring district were unavailable). ${ }^{144}$ That provision would have presented several difficulties. Initially, the district in which the search is to take place is not always the most appropriate district in which to present the application. While a search in a particular district ordinarily will relate to a crime committed in that district, occasionally local police investigating local offenses obtain probable cause to search premises located outside of the district. The application to search the out-district premises may, under some circumstances, be more appropriately presented to the local magistrate than to the magistrate of the district in which the premises are located. For example, a single showing of probable cause may relate to the search of different premises located both within and without the home district. Also, it may be preferable promptly to obtain the warrant in the district of investigation and request execution by the police in the district in which the place is located.145

Even if a specific district could be designated as the most appropriate in all cases, restricting the authority to issue warrants to magistrates of that district could prove pernicious. A search might be invalidated because the police were mistaken as to the district in which the searched place was located and presented the application to a judge of the wrong district. Similarly, if the unavailability of a local judge were a jurisdictional prerequisite to the issuance

district "on call" at all times. Judicial districts, however, often cover a fairly small geographical area (e.g., a single municipality). See section $1(c)$. There may often be two or three judicial districts, each containing only a single judge, in a small county. It would impose an unnecessary burden to make each of those judges remain on call. While district court magistrates could be utilized, the Committee did not desire to encourage the use of "part-time judges." With the telephonic application process available, a single judge in each county should be sufficient.

\footnotetext{
144. Several states allow judges to issue warrants only for searches "within the territorial jurisdiction of the court." Ohio R. CRIM. Prac. 4l(a). See also Fla. Stat. ANn. \$ 933.01 (1974); LA. CoDE CRIM. P, art. 161 (1967).

145. Thus, the "ordinary district" for application under section 2 includes both the district of the place to be searched and the district in which the underlying offense allegedly was committed.
} 
of a warrant by a judge of another district, the legislation would have to provide specific standards for "unavailability"; it would have to settle such questions as whether a local judge is "unavailable" when it would take one or two hours longer to present a petition to him than to a judge of another district. In light of these difficulties the Committee concluded that restricting search warrant authority to judges of certain districts (1) created a significant potential for confusion and inconvenience and (2) did not provide significant countervailing advantages, particularly in terms of preventing "judge shopping," that could not almost as effectively be provided by the discretionary authority granted in section $2[1]{ }^{140}$

\section{Telephonic Search Warrant Applications ${ }^{\mathbf{1 4 7}}$}

Under current practice, an applicant for a warrant must prepare a written affidavit and appear personally before a magistrate. Section $5[4]$ permits an alternative procedure-an oral application presented via telephone. This provision was not designed simply to avoid the "inconvenience" involved in making a trip to the courthouse. Paragraph (a) limits use of the telephonic application to situations in which there is reasonable cause to believe that the delay involved in bringing together the magistrate and the applicant "might result in loss or destruction of matter subject to seizure . . . " This standard permits telephonic applications where the evidence may be lost or destroyed due to delay, but where that possibility is not so great as to justify a search without a warrant under current constitutional standards. ${ }^{148}$

Vale $v$. Louisiana $a^{\mathbf{1 4 9}}$ illustrates the situation covered by section 5[4]. The officers in Vale lacked probable cause to search the defendant's home until after they had arrested him on his front porch. At that point, however, they could anticipate the possible return

146. See note 135 supra.

147. Nattonal Advisory Commisston, note 48 supra, Recommendation 4.2 urges "that every State enact legislation that provides for issuance of search warrants pursuant to telephoned petitions and affidavits from police officers." At least two states currently have such legislation. See ARIz. REv. STAT. ANN. \$\& 13-1444(c), -1445(c) (Supp. 1973); Cal. Pen. Code $\S \S$ 1526(b), 1528(b) (West Supp. 1974). Committee oN Rules of Practice and Procedure, Proposed Amendments to the federal Rules of Crtminal Procedure, Rule 41(c)(2) (Prelim. Draft 1973) [hereinafter Proposed AmendMENrs], would provide similar authority in federal courts.

148. The section $5[4]$ (a) standard is stated in terms of the reasonable likelihood that delay "might result," rather than "will result," in the possible loss of evidence. Compare section $5[2](c)$. This phrasing should permit the officer to give more weight to the potential for changed circumstances (e.g., the anticipated return of a resident). It should also permit reliance upon factors that create a potential for loss generally, without examining their particular application in a specific situation.

149. 399 U.S. 30 (1970). 
of other residents who might desire to assist the defendant. If the officers left the premises to apply for a warrant, those residents might destroy the evidence before the officers returned. The Court in Vale held that these circumstances did not justify dispensing with the warrant requirement. The majority only briefly commented upon the potential destruction of evidence, noting that the "goods ultimately seized were not in the process of destruction"150 as in Schmerber $v$. California. ${ }^{151}$ The facts of Vale support the Court's ruling, even if a warrantless search could be justified by a significant threat of destruction less imminent than that presented in Schmerber. ${ }^{152}$ First, when the officers initiated their search of the Vale home, they apparently had no specific basis for assuming that persons likely to destroy the evidence were about to return to the premises. ${ }^{153}$ Second, more than one officer was available, so the premises did not have to be left unprotected while an officer applied for a warrant. The Committee concluded that even though the potential costs of delay in cases such as Vale are insufficient to justify dispensing with the warrant requirement, they are certainly significant enough to justify a substantial effort to eliminate those costs through a provision like section 5[4].

Possible destruction of evidence in a "Vale situation" might be prevented by keeping the premises in "protective custody" while the warrant is sought. But this raises serious problems if the custody extends for any significant period. ${ }^{154}$ Of course, the officers at the scene might seek to reduce the period of "protective custody" by calling headquarters, relaying the relevant information to another

150. 399 U.S. at 35.

151. 384 U.S. 757 (1966). In Schmerber, the Court noted:

We are told that the percentage of alcohol in the blood begins to diminish shortly after drinking stops, as the body functions to eliminate it from the system. Particularly in a case such as this, where time had to be taken to bring the accused to a hospital and to investigate the scene of the accident, there was no time to seek out a magistrate and secure a warrant. Given these special facts, we conclude that the attempt to secure evidence of blood-alcohol content in this case was an appropriate incident to petitioner's arrest."

384 U.S. at 770-71.

152. See Johnson v. United States, 333 U.S. 10, 14-15 (1948).

153. Compare United States v. Bozada, 473 F.2d 389 (8th Cir.), cert. denied, 411 U.S. 969 (1973).

154. See notes 97, 101 supra. See also Shuey v. Superior Court, 30 Cal. App. 3d 535, 106 Cal. Rptr. 452 (1973), in which police officers were refused admittance to the defendant's apartment, but entered without invitation and placed considerable restraint on the residents' freedom while another officer obtained a warrant. Noting that the police had ample prior opportunity to obtain a warrant, the court held that the police action violated the fourth amendment; it left open the issue of what action is permissible when the police are faced with an emergency "not of their own making." 30 Cal. App. 3d at 541, $106 \mathrm{Cal}$. Rptr. at 456. 
officer, and having that officer obtain the warrant on his own application, using the "hearsay" from the officer at the scene. The second officer, however, still might experience significant delay in getting before the magistrate, particularly during evening hours. Moreover, this procedure would deprive the magistrate of the opportunity to examine the officer at the scene, who is in a much better position to answer questions relating to probable cause and the requisite scope of the search. ${ }^{155}$ The Committee concluded that the telephonic application process would provide a generally preferable procedure for eliminating the possible loss of evidence while protecting the legitimate interests of the owner and occupants of the place to be searched.

Section 5[4] preserves the essential safeguards of the traditional search warrant application procedure. The application is made under oath, and the applicant is subject to examination by the magistrate. The statement of factual grounds supporting probable cause is "frozen" at the time of the application since the officer's statement is recorded by a machine subject to the control of the court ${ }^{156}$ and transcribed at the court's direction "without unnecessary delay." The court approves and issues a specific warrant, and directs the officer to fill out copies to be served and returned as provided in section 12.157

The Committee recognized that the telephonic application pro-

155. Prosecuting attorneys in San Diego noted in an interview that magistrates there frequently asked questions during telephonic applications, and the questions often related to information that would not likely have been conveyed to a second officerfor example, "were you in uniform when they asked you these questions?"; "where were you standing when he invited you in?" Also, the judge occasionally gave the officer directions on conducting the search-for example, "all [you are] entitled to take from those premises is those things which [you have] asked for. Should anything else be found in there, [you] will need to get another search warrant." (In the particular case the judge later noted that this direction did not apply to contraband found in plain view.) See Transcript of telephonic search warrant application, Jan. 26, 1972, before Judge Robert Cooney, San Diego Municipal Court, on file with the Michigan Law Review. See also San Diego District Attorney, Manual on Telephonic Search Warrants (1971).

156. See Miller, Telephonic Search Warrants: The San Diego Experience, 9 THE Prosecutor 385 (1974), on the type of equipment and manner of operation that will ensure judicial control. The required recording provides a safeguard viewed by several courts as not constitutionally required, at least where the applicant testified in the presence of the magistrate. See Comment, Oral Search Warrants: A New Standard of Warrant Availability, 21 UCLA L. REv. 691, 697 (1973); note 137 supra. See also Proposed AMENDMENTs, note 147 supra, Rule 41 (c)(2) (requiring recording "unless it is impractical to do so").

157. The California courts have upheld the constitutionality of a similar procedure. See People v. Aguirre, 26 Cal. App. 3d 7, 103 Cal. Rptr. 153 (1972). See also Powelson v. Superior Court, 9 Cal. App. 3d 357, 88 Cal. Rptr. 8 (1970); Nakell, supra note 112, at 306-17; Comment, supra note 156. 
cedure may be challenged as providing less satisfactory safeguards than the traditional procedure in two respects: (1) the magistrate does not have before him the demeanor evidence of the applicant; and (2) the oral presentation of information may make it more difficult for the magistrate to evaluate fully the factual basis for the issuance of the warrant. ${ }^{158}$ The lack of demeanor evidence was not viewed as a matter of great concern-particularly in light of the current acceptability of affidavits based upon hearsay. ${ }^{159}$ The section $5[4]$ procedure gives the magistrate an opportunity to examine the source of the information, which would appear to be far more significant than the opportunity to observe and examine an applicant who has received all of his information from another. The oral form of the presentation was also viewed as unlikely to cause difficulty, although some note-taking (or playback of the tape) might be necessary in complicated cases. ${ }^{160}$ Nevertheless, to ensure that the information is properly presented, the Committee required that the oral application first be approved by the prosecuting attorney. It is anticipated that a conference call will be used in which prosecutor, officer, and magistrate will participate. This is common practice in California, where the officer usually presents the relevant information through answers to questions asked by the prosecutor. ${ }^{161}$ The statement of probable cause is thus presented in an orderly fashion and has not caused serious difficulty. ${ }^{162}$

158. See Comment, supra note 156, at 701-05. A few Committee members opposed the telephonic application procedure because of what they described as the "clandestine image" likely to attach to a procedure that permits a magistrate to issue an order from his own home in response to a police officer's "midnight call." The majority, however, viewed the transcription requirements, including judicial control of the recording equipment, as an appropriate response to any public concern as to the "clandestine" aspects of the procedure. It was noted also that the current procedure suggests an equally clandestine atmosphere when an officer goes to a magistrate's home to obtain a warrant in an emergency situation. See, e.g., People v. Eddington, 387 Mich. 551, 198 N.W.2d 297 (1972).

159. See Comment, supra note 156, at 701-03, suggesting that demeanor evidence is not likely to be significant in the warrant application process because, inter alia, "there is less pressure on the affiant in the ex parte warrant application than there is on a witness in an adversary proceeding," and "the affiant-usually a police officer who has testified on prior occasions-is accustomed to the warrant application process."

160. See Comment, supra note 156, at 703-05.

161. See, e.g., San Diego District Attorney, supra note 155; Los Angeles District Attorney, Instructions for Preparing Sworn Statements for Search Warrants (1971); Orange County District Attorney, Telephonic Search Warrant Guide (1973).

162. The prosecuting attorney's participation is also helpful in avoiding other pitfalls of telephonic applications. He can assure that each participant properly identifies himself before speaking and that crucial matters (e.g., names) are spelled out so as to avoid errors in the warrant. The prosecutor can also verify that the person seeking the warrant is an authorized peace officer. (In some California counties, verification is provided by using the police radio, which is available only to officers.) Interviews with 
In approving the telephonic application procedure, the Committee was influenced considerably by the successful use of that procedure in California. District Attorney Miller of San Diego has noted:

One of the main features of the telephonic system is its flexibility. In San Diego the system has been used for everything from a search for a stolen Van Gogh painting to a search for weapons used in a multiple slaying. In one instance, two affiants working on the same case were separated by some 60 miles from one another and yet were able to get their search warrant without delay. The use of multiple affiants is not uncommon; equipment is the only limitation. There have also been cases of use of the system by untrained, out-of-county officers who got their first look at the telephonic search warrant form at the time they were phoning to the deputy district attorney for a search warrant.

Speed and ease of operation is another great benefit of the telephonic search warrant system. The saving of time has been remarkable. In a recent survey, it was determined that $65 \%$ of all telephonic search warrants take one hour or less from the time when the officer in the field decides he wants a search warrant until the time of its issuance. Most of the remaining $35 \%$ are completed in less than 2 hours. Frequently, the delay can be attributed to lack of the necessary information to establish probable cause when the police officer first calls a deputy district attorney. ${ }^{103}$

Some Committee members would have permitted telephonic application in all cases. They viewed the personal appearance of the applicant and the written application as needless formalities. The Committee as a whole concluded, however, that it would be best to initiate use of the procedure under limited circumstances. In August 1972, the reporter discussed the use of the telephonic application procedure with members of the staff of the district attorney in San Diego. That office probably has made more extensive use of the procedure than has any other prosecuting agency in California. Although the California statute contains no time limitation, the district attorney's office generally does not permit police to use the procedure during "normal working hours," when judges would be readily available at the courthouse. Their approach emphasizes that application by affidavit remains the "usual procedure."104 The Com-

Edwin Miller, Jr., District Attorney of San Diego County; Tony Maino, Deputy District Attorney, San Diego County, August 4, 1972.

163. Miller, supra note 156 , at 386 .

164. In a typical four-month period after the telephonic procedure was well established (November 1971-February 1972), 36 telephonic warrants were issued in San Diego. All were issued between 6 p.m. and 8 a.m., with over two thirds issued between 
mittee agreed to incorporate a similar approach by including the potential-loss-of-evidence prerequisite in paragraph (a) of section 5[4]. This standard was thought preferable to leaving the restriction on use to the prosecutor's discretion (as in California ${ }^{165}$ ) or adopting the very general standard suggested in Proposed Federal Rule 41(c), which permits the use of oral testimony "when the circumstances make it reasonable to do so."166

\section{Affidavit Contents}

Notwithstanding the availability of forms and manuals, ${ }^{167}$ there appears to be some confusion concerning the current requirements governing the contents of the search warrant affidavit. ${ }^{188}$ While the current statutory provisions ${ }^{169}$ provide some help, the Committee concluded that a more detailed provision would be desirable. It recognized that complete explanation of the applicable requirements requires reference to the case law. Nevertheless, by including a general statement of each basic requirement, the statute could provide some minimal but readily accessible assistance to the officer and prosecutor in preparing the application, and to the magistrate in ruling upon it. Hopefully the more complete statutory statement would also suggest the complexity of certain requirements and the need to consult materials beyond the statute in attempting to meet those requirements.

6 p.m. and midnight. Reports from San Diego suggest that the telephonic application process often was used in situations where warrants formerly were not obtained. Interview with Edwin Miller, Jr., District Attorney, San Diego County, August 4, 1972.

165. Some California counties did adopt procedures to ensure that the telephonic application procedure was used only in "emergency" situations. See Los Angeles District Attorney, supra note 161.

166. See Proposed Amendments, supra note 147, Rule 41(c)(2).

167. See, e.g., G. Gillespie, Michican Grtminal LAw and Procedure \$\$ 868-73 (Supp. 1974); National District Attorneys Association, Manual on the Law of Search and Seizure (1973); D. Reisig \& E. Stafford, The Law of Arrest, Search and SEIzURE IN Mrchigan (1968). At least a few prosecutors' offices also have prepared detailed memoranda on special types of warrant applications, including checklists of relevant factors in establishing probable cause. See, e.g., P. Boyle, THE INFORMER AS the Basis for a SEARch WARRANT 4 (1974) (Wayne County Prosecutor's Office), listing, for example, the following factors as potentially relevant in showing the reliability of a first-time, unnamed, nonvictim informer: informer's statement constituted an admission against penal interest; officer's observations corroborating statement (as in a "controlled buy" situation); significant detail furnished in statement; accused person's reputation; and receipt of similar information from other first-time informers.

168. The experience of Committee members suggested that the confusion related more to "pleading requirements" than to the nature of probable cause. In part the confusion might be the product of the traditional use of conclusory statements in arrest warrant applications. See, e.g., People v. Burrill, 391 Mich. 124, 132, 214 N.W.2d 823, 827 (1974). See also note 120 supra.

169. Mich. CoMp. LAws ANN. §§ 780.651-.658 (1968). 
The Committee's primary concern in describing the contents of the search warrant application related to the allegations necessary to establish probable cause through hearsay. Prior to the 1966 statutory revision, Michigan did not permit probable cause to be established by hearsay. ${ }^{170}$ While section 780.653 now notes that probable cause may be shown by reliable hearsay obtained from a credible person, that provision does not adequately indicate how reliability is established. Proposed section 5[2] describes the primary means of establishing reliability as prescribed in various Supreme Court decisions: 171 setting forth "facts bearing on the informant's credibility and the means by which the informant obtained the information."172 To assist in establishing reliability, section 5[2] also permits submission of affidavits from other parties to support the allegations of the applicant. Finally, the section specifically notes that the special requirements relating to the presentation of hearsay apply to information obtained from a fellow officer. ${ }^{178}$

The Committee also made one substantive change in the provisions governing the use of hearsay. The draftsmen of the 1966 revision, seeking to avoid any difficulty in establishing informant reliability, required that the affidavit contain "affirmative allegations that the person [who 'supplied' information to the 'complainant'] spoke with personal knowledge of the matters contained therein."174 This provision apparently prohibits reliance on the hearsay of one

170. See, e.g., People v. Moten, 233 Mich. 169, 205 N.W. 506 (1933); People v. Perrin, 223 Mich. 132, 193 N.W. 888 (1923).

171. See, e.g., United States v. Harris, 403 U.S. 573, 578-79 (1971); Spinelli v. United States, 393 U.S. 410, 416 (1969).

172. Proposed section 5[2](d). To meet the basic standard set forth in section 5[2](d) -providing "allegations of fact establishing reasonable cause"-the affidavit must also set forth the "underlying circumstances upon which the informer concluded" that a crime had been committed, not merely the informer's conclusion alone. See Spinelli v. United States, 393 U.S. 410, 416 (1969).

The requirement that the affidavit state "facts bearing upon the informant's credibility" does not refer solely to independent factors, such as past reliability, that have frequently been noted in Supreme Court opinions. In some situations, the informant's status (e.g., victim or uninterested eyewitness) itself suggests credibility. See People v. White, 392 Mich. 404, 419 n.8, 221 N.W.2d 357, 364 n.7 (1974); Y. KAMISAR, W. LAFAVE \&. J. ISRAEL, supra note 50, at 250-51. Similarly, the requirement that the affidavit set forth the "means by which the informant obtained the information" does not require that the applicant include so complete a description (e.g., date and time of observation) as to reveal the informer's identity. Cf. ALI CoDE, supra note 5, \& SS 220.1(3) (affiant "shall disclose, as far as practicable, the means by which the information was obtained").

173. Thus, such information may not be described as based upon the "personal knowledge" of the second officer who submits the affidavit-a practice sometimes followed in arrest warrant applications. See People v. Burrill, 391 Mich, 124, 214 N.W.2d 823 (1974); People v. Hill, 44 Mich. App. 308, 205 N.Y.2d 267 (1973).

174. Mrch. Comp. LAWS ANN. $\$ 780.653$ (1968). 
informant who is repeating information he received from another informant. Such a prohibition is neither required constitutionally $y^{175}$ nor necessary to ensure reliability. Assume, for example, that officer $A$ discusses a crime with informant $C$, who has personal knowledge, and officer $B$ discusses the same crime with $D$, who also has personal knowledge. Officers $A$ and $B$ then compare their discussions. When officer $A$ decides to file the search warrant application, the current code permits him to rely upon the statement of $C$, but not upon the statement of $D$ since it was relayed to him by officer $B$. In fact, the officer may have as much knowledge concerning the reliability of $D$ 's statement as of $C$ 's, although he did not personally speak to $D$. It often will be crucial that someone "down the line" did have personal knowledge, but it does not serve the purpose of the search warrant process to allow only the person who spoke with that informant to file the application. Accordingly, section 5[2] eliminates the requirement of personal knowledge of the informant.

Proposed section 5 also includes standards relating to the description of the place or person to be searched and the items to be seized. Both standards admittedly are quite general, but they do provide some idea of the basic objectives to be met. The standard for description of the place or person-"sufficient particularity so as to identify a definitely ascertainable place or person"176_emerges from several Michigan opinions. ${ }^{177}$ Michigan cases, however, provide very little guidance concerning the description of the matter to be seized. Accordingly, the proposed standard-“"reasonable particularity" in light of the nature of the object and the offense allegedly committed ${ }^{178}$-is derived from federal cases. ${ }^{179}$ The requisite specificity will vary with the character of the item and its connection with the offense being investigated. With respect to certain items (e.g., money), the description must of necessity be general. With respect to other items, the description must relate to their use in connection with a particular crime (e.g., "books and records used in bookmaking," or "gambling paraphernalia"). ${ }^{180}$

175. See, e.g., United States v. McCoy, 478 F.2d 176 (10th Cir.), cert. denied, 414 U.S. 828 (1973); State v. Patterson, 83 Wash. 2d 49, 515 P.2d 496 (1973).

176. Proposed section 5[2](c).

177. See, e.g., People v. Ranes, 230 Mich. 384, 203 N.W. 77 (1925); People v. Lienartowicz, 225 Mich. 303, 196 N.W. 326 (1923); People v. Musk, 221 Mich. 578, 192 N.W. 485 (1922).

178. See proposed section $5[2](c)$.

179. See, e.g., Marron v. United States, 275 U.S. 192 (1927); James v. United States, 416 F.2d 467 (5th Cir. 1969), cert. denied, 397 U.S. 907 (1970).

180. See United States v. Honore, 450 F.2d 31 (9th Cir. 1972); United States v. Sharfman, 448 F.2d 1352 (2d Cir. 1971); James v. United States, 416 F.2d 467 (5th Cir. 


\section{Expanded Scope of Search and Seizures}

The Michigan Code currently lists the "property or other thing[s]" for which a search warrant may be issued. ${ }^{181}$ Although the Code provision is sufficiently broad to cover most searches, it fails to encourage full use of the search warrant because it does not encompass all constitutionally permissible searches. This lack of coverage is primarily of importance with respect to three special types of searches.

First, since the 1966 Code revision, the Supreme Court has expanded the concept of a "search" to encompass nontrespassory invasions of a person's reasonable expectation of privacy. ${ }^{182}$ Thus, there are now situations in which surveillance of a suspect's activities within a private area must meet fourth amendment standards-for example, where the officer observes through an opening (such as a vent) that is not a readily anticipated observation site. ${ }^{183}$ The current search warrant provisions do not specifically exclude "surveillance searches," but section 780.652 authorizes only searches for and seizures of "property or other thing[s]," a phrase that seems to limit warrants to searches for tangible objects. Surveillance searches, on the other hand, are designed to discover and "seize" information.

While surveillance searches are not common, they are particularly useful when police have probable cause to believe that an illegal activity (e.g., professional gambling) is occurring within a -particular building, but would prefer to observe the participants before entering the premises to make arrests. Very often these are situations in which police have invested a fair amount of investigative effort and in which the potential criminal liability extends to several persons. The success of the entire venture may be risked, however, if the police undertake a surveillance search without a search warrant. Although the arrests may still be valid as based upon previously obtained information, the police testimony as to what they observed prior to entry is likely to be suppressed if they had ample time to obtain a warrant before the surveillance search was undertaken. ${ }^{184}$ The proposed code enables police to obtain a

1969), cert. denied, 397 U.S. 907 (1970); Hastings v. Haug, 85 Mich. 87, 48 N.W. 294 (1891).

181. Mick. Comp. Laws ANN. \$ 780.652 (1968).

182. See Katz v. United States, 389 U.S. 347, 360 (1967) (Harlan, J., concurring).

183. See, e.g., Texas v. Gonzales, 388 F.2d 145, 147 (5th Cir. 1968); Lorenzana v. Superior Court, 9 Cal. 3d 626, 511 P.2d 33, 108 Cal. Rptr. 585 (1973); Cohen v. Superior Court, 5 Cal. App. 3d 429, 85 Cal. Rptr. 354 (1970); State v. Kent, 20 Utah 2d 1, 432 P.2d 64 (1967).

184. Cf. Texas v. Gonzales, 388 F.2d 145 (5th Cir. 1968); Lorenzana v. Superior Court, 9 Cal. 3d 626, 511 P.2d 33, 108 Cal. Rptr. 585 (1973). 
warrant in such situations. ${ }^{185}$ Section 6 authorizes the issuance of a warrant to search for and seize any "matter" that constitutes evidence of a crime, and the definition of "matter" in section $1(f)$ includes "the obtaining of incorporeal information by sensory perception ...." While the proposed execution provisions would be incompatible with authorization of lengthy surveillance searches, ${ }^{188}$ a court could authorize observation for short periods to ensure that the criminal activities were underway before officials entered the premises to make an arrest. Revised section 6 also eliminates any question of the availability of warrants where the police desire to enter a building to take photographs or otherwise inspect the premises but do not intend to seize any tangible item.

A second defect of the current statute is its failure to authorize issuance of warrants to search for a person to be arrested.187 Courts generally have held that, even where ample time exists, an officer need not obtain a warrant before entering a building to make an arrest; this rule applies even though the officer may have to undertake a fairly thorough search of the premises to find the suspect. ${ }^{188}$ There are arrest situations, however, in which officers may desire

185. The Code does not, however, provide any standard for determining when a search warrant is constitutionally required-that is, when surveillance constitutes a "search." The Committee concluded that, as with the probable cause standard, see text at notes 15-17 supra, an appropriate legislative definition of what constitutes a "search" could only reiterate the standard established by judicial decisions such as Katz v. United States, 389 U.S. 347 (1967).

186. The Committee decided not to consider proposed electronic eavesdropping in view of the legislature's recent rejection of legislation authorizing such surveillance. Of course, nonconsensual electronic eavesdropping, even for a limited period, is barred by federal statute unless the state adopts a provision meeting the requirements of federal law. See 18 U.S.G. \$\$ 2510-20 (1970).

187. Mrch. Comp. Laws ANN. \& 780.652(f) (1968) permits a search only for "[t]he bodies or persons of human beings . . . who may be the victims of a criminal offense." See Mrch. CoMp. LAws ANN. \$§ 750.54, .136 (1968) (authorizing warrants to search a building for persons believed to be engaged in specified crimes).

188. See, e.g., People v. Sprovieri, 95 IIl. App. 2d 10, 238 N.E.2d 115 (1968), affd., 43 III. 2d 223, 252 N.E.2d 531 (1969); People v. Eddington, 23 Mich. App. 210, 178 N.W.2d 686 (1970), affd., 387 Mich. 551, 198 N.W.2d 297 (1972); People v. Herrera, 19 Mich. App. 216, 172 N.W.2d 529 (1969). See also Note, The Neglected Fourth Amendment Problem in Arrest Entries, 23 StAN. L. REv. 995 (1971). Note, however, the suggestion in Coolidge v. New Hampshire, 403 U.S. 443,480 (1971), that the Constitution may require that, where practicable, an officer obtain an arrest warrant before entering a household to make an arrest. See also Jones v. United States, 357 U.S. 493, 499-500 (1958) (forceful nighttime entry into a dwelling to make an arrest without a warrant may pose a "grave constitutional question"); Dorman v. United States, 435 F.2d 385 (D.C. Cir. 1970) (warrant required unless warrantless entry is justified by exceptional circumstances). Although these opinions speak in terms of an arrest warrant, it seems that a search warrant requirement would be more appropriate because the courts' primary concern apparently relates to the invasion of privacy involved in the entry into the house, rather than in the seizure of the person. See also Trupiano v. United States, 334 U.S. 699 (1948); Y. Kamisar, W. LAFAve \&. J. IsRaEI, supra note 50, at 312. Compare ALI CODE, supra note 5, at 145. 
to obtain search warrants. In particular, a warrant may offer significant advantages if the police believe that a suspect is being harbored in the residence of another person. An entry into a private building for the purpose of making an arrest must be based upon reasonable grounds to believe that the suspect is on the premises. ${ }^{180}$ While courts tend to assume almost automatically that a reasonable basis exists when the suspect's own residence is involved, ${ }^{100}$ the degree of probability needed for entry upon the premises of another remains somewhat unclear. ${ }^{191}$ Advance judicial approval would be

189. See, e.g., United States v. Phillips, 497 F.2d 1131, 1136 (9th Cir. 1974); United States v. Brown, 467 F.2d 419, 423 (D.C. Cir. 1972); United States v. McKinney, 379 F.2d 259, 263 (6th Cir. 1967); Lankford v. Gelston, 364 F.2d 197, 202-03 (4th Cir. 1966). See also Note, supra note 188, at 996-97.

190. See, e.g., Ker v. California, 374 U.S. 23, 28 (1963); United States v. Dudley, 352 F. Supp. 1140 (E.D. Mich. 1972); People v. Sprovieri, 95 III. App. 2d 10, 238 N.E.2d 115 (1968), affd., 43 Ill. 2d 219, 252 N.E.2d 531 (1969). See also People v. Valot, 33 Mich. App. 49, 52, 189 N.W.2d 873, 875 (1971); People v. Eddington, 23 Mich. App. 210, 221, 178 N.W.2d 686, 691-92 (1970), affd., 387 Mich. 551, 198 N.W.2d 297 (1972). Lower court decisions have suggested that the officer must have "reasonable grounds to believe that [the defendant] was in [his residence] when it was entered." United States v. Harris, 391 F.2d 384 (6th Cir. 1968). See also United States v. Alexander, 346 F.2d 561 (6th Cir. 1965), cert. denied, 382 U.S. 993 (1966); People v. Valot, 33 Mich. App. 49, 189 N.W.2d 873 (1971). Cf. Jones v. United States, 357 U.S. 493, 499-500 (1958). However, decisions trequently have found that regular residence in a dwelling, without more (e.g., car in drivervay), furnishes such reasonable belief. See, e.g., United States v. Dudley, 352 F. Supp. 1140 (E.D. Mich. 1972); People v. Sprovieri, 95111. App. 2d 10, 238 N.E.2d 115 (1968), affd., 43 Ill. 2d 219, 252 N.E.2d 531 (1969). See also Dorman v. United States, 435 F.2d 385, 393 (D.C. Cir. 1970) (there "was no special knowledge that [the defendant] was home, but concepts of probable cause and reasonableness prima facie justifi[ed] looking for a man at home" at 10:20 p.m.). It is debatable whether residence alone provides the same degree of probability of success as is required for probable cause to enter a dwelling to make a search for evidence. See Y. KAMISAR, W. LAFAVE \& J. IsRAFt, supra note 50, at 276 n.2(b), 312 n.2. Cf. Pcople v. Sprovieri, 95 Ill. App. 2d 10, 14, 238 N.E.2d 115, 118 (1968), affd., 43 Ill. 2d 219, 252 N.E.2d 531 (1969) (sustaining entry on the ground, inter alia, that "rudimentary police procedure dictates that a suspect's residence be eliminated as a possible hiding place before a search is conducted elsewhere' $)$.

191. Compare United States v. Phillips, 497 F.2d 1131 (9th Cir. 1974), with United States v. Brown, 467 F.2d 419 (D.C. Cir. 1972). In Phillips two narcotics dealers, in the presence of an undercover agent, called Phillips' office and placed an order for naxcotics. One of the dealers asked initially to speak to Phillips, and then said, "well, all right, I'll talk to you," and placed an order. The dealers then drove to Phillips' office, entered the building, remained inside for a short time, and returned to their home. In the meantime, a group of officers entered Phillips' office (using a ruse) to arrest him. A divided court of appeals held that the officers "did not have probable cause to believe that Phillips was in the office building at the time of the raid," 497 F.2d at 1136, and therefore the entry and Phillips' subsequent arrest were invalid. A dissenting judge noted that "the probabilities" would "preponderate in favor of Phillips' being in his building where all the action was, rather than at home or somewhere else." 497 F.2d at 1136-37. The dissent relied heavily on Dorman v. Unitcd States, 435 F.2d 385 (D.C. Cir. 1970) (see note 190 supra). In Brown, police had established a surveillance of the apartment building in which Brown's "number one girl friend," Nadine Frazier, resided. 467 F.2d at 421. A security guard had "sometimes observed [Brown] frequent the building in company with Miss Frazier." 467 F.2d at 421. At 11 p.m., the officers observed two men enter the apartment building by use 
desirable to meet any subsequent legal challenge either in the form of a civil suit or a motion to suppress evidence obtained in the course of the search for the person. ${ }^{182}$ Such searches may also present difficult problems of community relations--particularly where the suspect is not found on the premises-and the warrant may be helpful in gaining acceptance of the search. ${ }^{193}$ Here again we are dealing with situations that are somewhat unusual, but the encouraged use of the search warrant process in these situations may eventually lead to its more frequent use in arrest situations generally.

A third difficulty presented by the current search warrant statute relates to searches of a person. Most such searches are conducted incident to an arrest, and warrants therefore are not needed. There are situations, however, in which police may desire an advance magisterial determination that probable cause exists for the search of an arrested person. ${ }^{194}$ Notwithstanding United States $v$. Edwards, ${ }^{195}$ of a key. Shortly thereafter, "a light came on in the window in the vicinity of [Miss Frazier's apartment]." 467 F.2d at 421 . The officers acknowledged that they "had no reason to believe" that either of the men was Brown, aside from the subsequent showing of lights. The officers returned to headquarters, and at 5:20 a.m. officers demanded entry (and were eventually admitted) to Miss Frazier's apartment, where they found Brown. The court held that the officers had "probable cause... to enter [that] apartment to search for Brown." 467 F.2d at 424. The court recognized that the wait from 11 p.m. to 5 a.m. "diminished to some indeterminate extent the likelihood that Brown was still in the apartment," but not to the extent "as to condemn the police action as lacking in probable cause-which is essentially a concept of reasonableness." 467 F.2d at 424. The opinion noted:

It is material that what the police were executing was a warrant to arrest a dangerous, usually armed man who was involved in a narcotics operation and was wanted for murder; and it was reasonable, in terms of prudent police action and the avoidance of the dangers attendant an armed resistance, to wait for the quiet hours to enter the apartment of his best girl friend, and to presume that he had stayed on from 11 p.m. to 5 a.m.

467 F.2d at 424. See also United States v. McKinney, 379 F.2d 209 (6th Cir. 1967); England v. State, 488 P.2d 1347 (Okla. Crim. App. 1971).

192. See, e.g., United States v. Brown, 467 F.2d 419 (D.G. Cir. 1972); United States v. McKinney, 379 F.2d 209 (6th Cir. 1967). Cf. Lankford v. Gelston, 364 F.2d 197 (4th Cir. 1966).

193. Indeed, this may be true even when the individual is found on the premises. Consider, for example, the problems faced by the FBI a few years ago when some churches provided an "open refuge" to persons subject to arrest for draft evasion.

194. There also may be some situations in which a search of the person pursuant to a warrant provides a better alternative than an arrest. See, e.g., L. TIFFANY, D. MCINTYRE \& D. RoTENBERG, supra note 122 , at $101 \mathrm{n} .8$ :

In Chicago, occasionally, search warrants are obtained for a search of an individual when a raid is conducted against premises used for commercialized gambling. The suspect may not be in the building when the raid takes place. He can be located, perhaps on the street, and searched without the need to arrest and then released if nothing is found. If he is arrested, the police feel compelled to take him to the station even though incriminating evidence is not found. . . [ ] t is suggested a search warrant is appropriate when an officer wishes to search the person of an apparently innocent suspect carrying contraband by mistake or as a result of trickery or fraud by another; but this suggestion assumes there are no grounds to arrest him. [Emphasis original.]

195. 415 U.S. 800 (1974). See text at notes 95-97 supra. 
there may be limits on the examination of clothing as part of an "inventory search." Certainly if police make a scientific analysis of the defendant's clothing, they should have probable cause (as the police had in Edwards) to believe that the analysis will reveal incriminating evidence. ${ }^{196}$ Moreover, even when probable cause is clear, the general rule authorizing a warrantless search incident to an arrest may not apply if the search involves an invasion of the privacy of the body (e.g., the removal of items from body cavities). Thus, in Schmerber $v$. California ${ }^{197}$ the Court suggested that the taking of a blood sample without a warrant could not be upheld simply as a search incident to an arrest. ${ }^{108}$ The Court upheld the

196. The Edwards opinion noted that the lower court had found probable cause, and the only issue before the Supreme Court was whether "a warrant should have been secured." 415 U.S. at 808 n.9. The Court also noted that even where the warrant clause of the fourth amendment is "inapplicable," the police conduct must still be "tested by the Fourth Amendment's general proscription against unreasonable searches and seizures." 415 U.S. at 808 n.9, quoting Terry v. Ohio, 392 U.S. 1, 20 (1968).

While the Edwards opinion further noted that "[w]ith or without probable cause, the authorities were entitled at this point not only to search Edwards' clothing, but also to take it from him and keep it in official custody," 415 U.S. at 804, that reference arguably was only to a search and retention of the clothing for custodial purposes. Although scientific analysis does not entail a substantially greater invasion of privacy', it serves only an investigatory function, and searches for that purpose ordinarily require probable cause. Thus, while Michigan courts have frequently upheld traditional inventory searches of arrested persons, see, e.g., People v. Robinson, 388 Mich. 630, 202 N.W.2d 288 (1972); People v. Dixon, 45 Mich. App. 64, 205 N.W.2d 852 (1973), in People v. Trudeau, 385 Mich. 276, 187 N.W.2d 890 (1970), cert. denied, 405 U.S. 965 (1972), the seizure and scientific examination of a jail inmate's shoes for the purpose of determining whether the inmate had committed a homicide was held invalid for lack of probable cause.

197. 384 U.S. 757 (1966).

198. The majority opinion noted:

Whatever the validity of these considerations [authorizing a search of the person when legally arrested] in general, they have little applicability with respect to searches involving intrusions beyond the body's surface. The interests in human dignity and privacy which the Fourth Amendment protects forbid any such intrusions on the mere chance that desired evidence might be obtained. In the absence of a clear indication that in fact such evidence will be found, these fundamental human interests require law officers to suffer the risk that such evidence may disappear unless there is an immediate search. . . . Search warrants are ordinarily required for searches of dwellings, and, absent an emergency, no less could be required where intrusions into the human body are concerned. . . . The importance of informed, detached and deliberate determinations of the issue whether or not to invade another's body in search of evidence of guilt is indisputable and great. ... The officer in the present case, however, might reasonably have believed that he was confronted with an emergency, in which the delay necessary to obtain a warrant, under the circumistances, threatened "the destruction of evidence."

384 U.S. at 769-70. See also Cupp v. Murphy, 412 U.S. 291, 296 (1973), upholding the taking of fingernail scrapings without a warrant as a "very limited search necessary to preserve the highly evanescent evidence ... found under ... . [defendant's] fingernails ...."

In United States v. Edwards, 415 U.S. 800 (1974), the Court specifically noted that it was "not conclud[ing] that the Warrant Clause of the Fourth Amendment is never applicable to the postarrest seizures of the effects of an arrestee." 415 U.S. at 808. It also noted that it was not "express[ing] a view concerning those circumstances sur. rounding custodial searches incident to incarceration which might violate the dictates 
search in Schmerber on the ground that delay in obtaining the warrant would result in the loss of the relevant evidence. ${ }^{100}$ There may, however, be some searches of the body (e.g., removal of foreign substances) that do not present such urgency. In such instances, a warrant should be obtained, to ensure both that there is probable cause and that the method of extraction is reasonable. ${ }^{200}$

The current code arguably does not authorize warrants for the search of a person. Section 780.651 provides that a warrant may be obtained "to search the house, building or other location or place where the property or thing which is to be searched for and seized is situated." While the term "Iocation or place" may be sufficiently broad to cover the search of a person's clothing or body, that interpretation is at least debatable. Proposed section 7[1] avoids such ambiguity by specifically providing for warrants authorizing the search of an "object" or a "person."201

\section{Ordinance Violations}

After considerable discussion the Committee concluded that its policy of encouraging use of search warrants did not require that the warrant process be available for investigations related solely to local ordinance violations. The vast majority of local ordinances carrying a potential punishment of imprisonment merely duplicate state misdemeanor provisions. Ordinances that create "new offenses"

of reason either because of their number or their manner of perpetration.' . . . CE. Shmerber v. California .. . ." 415 U.S. at 808 n.9, quoting Charles v. United States, 278 F.2d 386, 389 (9th Cir.), cert. denied, 364 U.S. 831 (1960).

199. See note 151 supra.

200. In Schmerber the Court stressed both the strength of the probable cause, 384 U.S. at 768-70, and the "reasonable manner" in which the blood test was performed. 384 U.S. at 771-72. ALI CoDE, supra note 5, \& SS 230.3(2), similarly requires consideration of both of these factors in authorizing a warrantless "[s] earch of an arrested individual's blood stream, body cavities, and subcutaneous tissues." Section SS 230.3(2) allows such a search incidental to an arrest if

there is a strong probability that it will disclose things subject to seizure and re-

lated to the offense for which the individual was arrested, and if it reasonably appears that the delay consequent upon procurement of a search warrant would

probably result in the disappearance or destruction of the objects of the search, and that the search is otherwise reasonable under the circumstances of the case, including the seriousness of the offense and the nature of the physical invasion of the individual's person.

Proposed section 5 does not specify the types of intrusions upon the body that may be authorized pursuant to a warrant. Certainly section 22 should not be viewed as a suggested limitation. The procedures listed in section 22 are geared to a particular problem, establishing identity, and assume the lack of full-fledged probable cause, Compare with respect to search warrant authorization Creamer v. State, $229 \mathrm{Ga}$. 511, 192 S.E.2d 350 (1972), with Adams v. State, - Ind. -, 299 N.E.2d 834 (1973), cert. denied, 415 U.S. 935 (1974).

201. Section $7[1]$ refers to search of a "person" or "place." Under section 1(i) "place" includes any "object." 
apart from state law relate primarily to regulatory matters of local concern. ${ }^{202}$ Conviction under these provisions rarely results in a jail sentence. Indeed, the offenses tend to be treated in most respects as more civil than criminal in nature. Any search warrant authority required for the enforcement of such ordinances can be provided by administrative search provisions. A small number of local ordinances do create "new offenses" with respect to activities that traditionally fall within the "criminal sphere." Most of these ordinances deal with matters quite similar to state offenses but depart from state law in defining the prohibited offense. ${ }^{203}$ The differences ordinarily are not so substantial that probable cause relating to the ordinance violation will not also suffice for a state offense. ${ }^{204}$ Moreover, the Committee concluded that, should the differences in state and local law be that significant, the investigation of the possible ordinance violation certainly should not include a search beyond that needed incident to an arrest. If enforcement of a legislative prohibition requires extensive searches of the type undertaken pursuant to a warrant, the state legislature, rather than the local city council, should make the determination as to whether the prohibition justifies that cost.

On the basis of the foregoing analysis, the proposed revision creates a distinction between state and local offenses that extends throughout the revision. Provisions authorizing search warrants refer only to searches for matter relating to a "state offense."205 This limitation appears to be consistent with current law. ${ }^{208}$

202. See, e.g., ANN ARBor, Mich., CrTY CoDE \& 1:13 (1974), authorizing imprisonment for not more than 90 days for most code violations, including construction in a residential area between the hours of $8 \mathrm{p.m}$. and $7 \mathrm{a.m.,}$ ANN ARBor, MIcH., CiTY CODE \& 9:13(9) (1974), and selling pastries not in a "clean and sanitary container . . . sufficiently tight and compact to exclude all dust and dirt and other contamination." AnN Arbor, Mrch., CrTy Code \& 6:191 (1974). See also ANn Arbor, Mrch., Crry Code \$ 8:366 (1974) (providing separate criminal penalties for violation of refrigeration code).

203. See, e.g., ANN ARbor, MrCh., CrTY CODE § 9:62 (1974) (describing various forms of "disorderly conduct"). On local authority to depart from state law in dealing with matters governed by the state Code of Criminal Procedure, see Note, The Concurrent State and Local Regulation of Marijuana: The Validity of the Ann Arbor Marijuana Ordinance, 71 Mich. L. REv. 400 (1972).

204. Compare, e.g., ANN ARBor, Mrch., City CoDE § 9:62(11) (1974) with Mich. Comp. LAWS ANN. \$ 750.167 (Supp. 1974-1975) (both prohibiting prostitution); ANN ARbor, Mrcf., Citr Code \& 9:62(19) (1972) with Mrch. Comp. LAws ANN. \$ 750.356 (1968) (both prohibiting larceny). On the other hand, some ordinance offenses, such as those directed at particular types of "obnoxious" or "harassing" public behavior, may have no close counterpart in the state code. See, e.g., ANN ARbor, Mrch., CrrX CODE $\S 9: 62(6)$ (1974) (prohibiting the following of an individual without lawful justification where the actor "should know that said individual is likely to be caused alarm"). Most such offenses are unlikely to require searches beyond those incident to an arrest.

205. See, e.g., proposed sections 5[2], 7[1]. The Committee also limited section 18[1] 


\section{Executing Warrants}

The Committee's basic approach in dealing with the execution of warrants was to retain all provisions that significantly implement the protective function of the warrant procedure while eliminating those provisions that impose burdens without providing offsetting protective benefits. In addition, the Committee sought to establish clearly the legality of certain important and commonly utilized procedures that are not treated in current provisions.

Perhaps the most troublesome problem relates to the timing of service of the warrant. The Committee recognized that service may be an important factor in gaining the occupant's acceptance of the search. The served warrant may also assist the occupant in determining whether to challenge the search. For these reasons section 12 expands present law by requiring service of the warrant in all cases -not merely when property is seized. ${ }^{207}$ Section 12 , however, departs from current law by permitting service of the warrant at the time of the search or "as soon thereafter as is reasonably practicable." The present Code provides that "[t]he officer taking property or other things under the warrant shall forthwith give to the person from whom or from whose premises the property was taken a copy of the warrant . . . "208 If that person is not present, the Code directs the officer to leave a copy "at the place from which the property or thing was taken." 209

In order to comply with the current Code, the officer executing the search must have a copy of the warrant in his possession. While it is desirable that he have a copy, a requirement to that effect does not permit sufficient flexibility in the execution of warrants. Situations may arise in which it is appropriate that an officer other than the one who obtained the warrant execute it. Section 8 permits service by another officer, since the magistrate may authorize "any officer" within the state to execute the warrant. Thus, one officer may obtain a warrant and then notify a second officer closer to the scene who may conduct the search. The Committee did not view

to searches for matter relating to "state offenses." If extensive searches for evidence of ordinance violations should not be authorized by warrant, neither should they be authorized without a warrant under the "exigent circumstances" doctrine.

206. Mrch. CoMp. LAws ANn. § 780.651 (1968) provides for issuance of a search warrant in "criminal cases"-a phrase that has been interpreted in a related context as limited to prosecutions under "state laws." See Mixer v. Board of Supervisors, 26 Mich. 422 (1873). See also Mrch. Comp. LAws ANN. § 780.652 (1968).

207. Compare Mrce. CoMp. Laws ANN. $\$ 780.655$ (1968).

208. Mich. CoMp. LAwS ANN. \& 780.655 (1968).

209. Mraf. CoMp. LAwS ANN. \& 780.655 (1968). 
this as a procedure to be commonly utilized. There may be situations, however, in which the officer having the best knowledge of the grounds for probable cause is far removed from the premises to be searched.210 If execution by another seems appropriate in light of the other factors involved-such as the simple nature of the search, the availability of other officers at the scene, and the likely absence of any adverse response even if the executing officer is unable to show a warrant-the court should have the power to authorize execution by other officers. ${ }^{211}$

Similar flexibility should apply to the preparation and service of the receipt. The current Code requires that an officer seizing property prepare a "complete and accurate" tabulation of the items seized, "in the presence of the person from whose... premises the property or thing was taken, if present, or in the presence of at least one other person ...."212 The officers must then either present the tabulation to the person from whom the property was taken or leave it at the premises. The receipt assures the occupant that the seizure of the property is officially recognized (that is, the police will not claim the property was never taken). It also may assist defense counsel in determining whether to challenge the search. Finally, it assists the police in providing for the correct disposition of the property, including its return where appropriate. Only the first of these functions is substantially served by having the inventory taken in the presence of the occupant. While it may reduce the occupant's anxiety, preparation in his presence is not so essential as to be required under all circumstances. Where the search pursuant to a warrant is accompanied by an arrest, it may be desirable to remove the arrestee from the premises before the search is completed.213 It is not entirely clear whether the current pro-

210. Cf. text at notes $144-45$ supra.

211. Under section $8[\mathrm{~b}]$ the court may designate the executing officer by name, department, or classification. Indeed, the proposed section is sufficiently broad that warrants could be obtained to search a vehicle when its current whereabouts are unknown. The court could authorize execution of the warrant by any officer in the state, and any officer who stopped the vehicle (after being informed of the warrant) could conduct the search. The warrant execution procedure would thus be similar to the procedure permitted under current law for the execution of arrést warrants. Mich. CoMp. LAws ANN. \& 764.18 (1968) provides that the officer executing an arrest warrant need not have the warrant in his possession, but shall inform the person that there is a warrant and shall "show ... [the] warrant if required, as soon as practicable" after the arrest.

212. Mrch. Comp. LAwS ANN. $\$ 708.655$ (1968).

213. Although most searches can be conducted promptly, certain searches (e.g., the search of premises used for bookmaking) may take several hours, because the inventory is likely to be quite extensive. Also, there are occasions when even a relatively limited search may have to be conducted intermittently, so that the overall period 
vision permits this procedure. ${ }^{214}$ Assuming that the person can be removed, the police must then find another person in whose presence the tabulation may be made. The same need would also exist in cases in which the premises are empty when the police arrive. The police may rely upon the assistance of neighbors in such situations, but neighbors may not be available. Thus, to be positive that one other person will be present, the police must use a two-officer search team (a desirable but not always feasible practice).

Even if an occupant is on the premises during the search, it may be impracticable to make a complete tabulation in his presence. Good police practice ordinarily suggests that any items seized immediately be packaged and marked in the presence of the occupant, so as to avoid subsequent claims that not all valuables taken were tabulated. ${ }^{215}$ Where a large quantity of items of several types have been seized, however, it may be quite difficult for the officers immediately to prepare a "complete tabulation" that includes the precise number of items of each type. ${ }^{216}$ Indeed, in some situations, it is impracticable to prepare even a fairly general receipt at the time of the seizure. Where the property is subject to rapid disintegration, it may be necessary to remove it immediately to a laboratory for preservation. Similarly, where a closed container is obtained from an arrested person, there is little reason to take an inventory when the container and the person are to be removed promptly to the station, where the contents of the container may be examined in his presence. The Committee concluded that the only standard that could accommodate all of these situations would be one geared to "practicability." Accordingly, section 20 requires that the receipt

of the search encompasses several hours. In one recent case the search had to be conducted over a two-day period because of tear gas. Statement of William Morris during Committee proceedings, June 28, 1971. See proposed section 9[3].

Police have expressed concern that if they keep the arrestee on the premises during an extended search, their action will be challenged by the defense on the ground that it delayed the defendant's prompt presentment before a magistrate. Also, from a defense counsel's viewpoint, removal will be preferred lest the defendant make an incriminating statement in response to the discovery of evidence in his presence.

214. The current statute requires that the tabulation be prepared in the presence of the person "from whose ... premises the property was taken, if present . . .." Mrch. Comp. Laws ANN. $\S 780.655$ (1968) (emphasis added). This provision does not specifically restrict police authority to remove that person when he has been arrested. It may be argued, however, that to permit removal is to undermine the tabulation-inthe-presence requirement, at least where the person is not obstreperous.

215. See Project on Law Enforcement Policy and Rulemaking, Model Rules FOR LAW ENFORGEMENT-SEARGH WarRant Execution, Rules 303, 305 [hereinafter PLE Search Warrant Execution]. Cf. Michigan State Police, General Procedures for Handling Evidence, C.11502 (Nov. 1, 1972).

216. See, e.g., People v. McLott, 55 Mich. App. 198, 222 N.W.2d 178 (1974). 
be prepared, signed, and served as soon after the seizure as is "reasonably practicable."217

Another aspect of warrant execution treated in the Committee's proposal is the scope of the permissible seizure by an officer executing a warrant. The current Code refers only to the seizure of property "under the warrant."218 This language, combined with a prohibition era ruling stating that the officer may seize only items specified in the warrant, ${ }^{219}$ has caused some confusion concerning the officer's authority to seize other evidence discovered in the reasonable course of a search under a warrant. Recent cases establish that the seizure of such items is constitutionally permissible under the "plain view doctrine," provided that the officer has probable cause to believe that items seized constitute evidence of a crime. ${ }^{220}$ Section 15 restates this principle, and should thereby eliminate any confusion on this score, although it admittedly provides little help in determining precisely what constitutes the "reasonable course" of a search under a warrant.

The Committee also sought to eliminate any uncertainty concerning the public record status of warrants and warrant applications. Although judges commonly view the search warrant determination as a closed proceeding, no current provision excludes warrants and warrant applications from the public record. ${ }^{221}$ As a matter of prac-

217. ALI CoDE, supra note $5, \S$ SS 280.2 similarly requires that in "all cases of seizure other than pursuant to a search warrant, the officer making the seizure shall, as soon as is reasonably possible," file a report "with a list of things seized . . . ." However, section SS 220.3(6), governing searches pursuant to a warrant, is similar to Mich. CoMp. LAws ANN. \& 780.655 (1968). That All section requires that the list be prepared "[u]pon completion of the search" in the presence of the "person in apparent control of the premises ...." Where the premises are unoccupied, the executing officer is directed to secure the presence of one or more apparently credible persons "if practicable." The ALI commentary does not offer any explanation as to why different standards are applied to searches with and without warrants. The Michigan Committee found no justification for imposing a more rigid timing requirement where the search was undertaken pursuant to a warrant, particularly in light of the Committee policy to encourage the use of search warrants.

218. Mich. Comp. LAws ANn. § 780.655 (1968).

219. In People v. Preuss, 225 Mich. 115, 195 N.W. 684 (1923), the officer was directed by the warrant to search for stolen beans. While searching for the beans he came across seven gallons of moonshine whiskey, which he seized. The court questioned the validity of the affidavit supporting the warrant, but concluded that, even if the warrant was viewed as "fair on its face and [therefore] protected the officer," the seizure of evidence other than that specified in the warrant made the officer a trespasser and required suppression of the evidence. 225 Mich. at 118, 195 N.W. at 685.

220. See, e.g., Coolidge v. New Hampshire, 403 U.S. 443, 465 (1971); United States v. McDonnell, 315 F. Supp. 152 (D. Neb. 1970); People v. Imbrunone, 5 Mich. App. 42, 145 N.W.2d 844 (1966).

221. Mrch. Comp. LAWs ANN. $\$ 780.655$ (1968) provides that the tabulation of the items seized "may be suppressed by order of the court until the final disposition of the case ... ." The Committee found no need for suppression of the receipt since 
tice, warrants are not filed with public records of judicial proceedings prior to their return. Section 7[3] specifically approves this policy of nondisclosure, which is necessary to ensure effective execution. In some instances, a warrant may be returned unexecuted for reasons that suggest that a request will subsequently be made for another warrant in connection with the same investigation. Accordingly, section 7[3] also extends the disclosure prohibition to warrants that are returned unexecuted, except that disclosure may be ordered by the magistrate or by another judge in connection with a judicial proceeding.

It should be emphasized that the Committee did not view itself as necessarily bound by current procedures governing execution of warrants. For example, it considered proposing a new provision requiring that warrants be executed during the daytime unless the court authorizes nighttime execution upon a showing of special need. ${ }^{222}$ After weighing the interests involved, the Committee decided to place no limitations upon nighttime execution. The effective utilization of the search warrant often requires an evening search. Warrants are commonly used in the investigation of criminal activity that occurs during the evening. ${ }^{223}$ Also, as noted above, ${ }^{224}$ information concerning illegal activity of all sorts is frequently obtained from informants available primarily during evening hours. Once reasonable cause is established, the search usually should be made forthwith because the possibility always exists that the items to be seized might otherwise be removed or destroyed. The Committee concluded that there would be little value in imposing a daytime-execution requirement if an exception were permitted in every case in which an evening search might be somewhat more effective. A daytime-execution provision would only be justified if the interests of the individual in not being disturbed during the evening

the warrant has already been executed at that point. Of course, where pretrial publicity threatens a fair trial, the court may take appropriate measures relating to disclosure generally. See ABA Project on Standards for Griminal Justice, Standards Relating to Fair Trial and free Press (Approved Draft 1968).

222. A number of jurisdictions have such provisions. See, e.g., N.Y. CRIM. P. LAW \$ 690.30(2) (McKinney 1971); OHIo R. CRIM. P. 41(c). See also AlI Code, supra note 5, $\S$ SS 220.2(3). Michigan formerly had such a provision but repealed it in 1929. See Public Act of 1927, Mich. Session Laws No. 175, ch. 16, \& 4 (May 14, 1927), repealed by Public Act of 1929, Mich. Session Laws No. 24, ch. 16, § 2 (April 2, 1929).

223. Warrants are frequently sought in connection with "raids" of dwellings being used for illegal enterprises. See ALI CODE, supra note 5, at 156-57. Raids in connection with certain types of gambling and the narcotics trade are frequently made during the evening, when the illegal activity is at its height.

224. See text at notes 141-43 supra. 
hours ordinarily would offset the risk to the effectiveness of the search. The Committee concluded that they would not. First, evening searches are not necessarily more "alarming" or "dangerprovoking" than daytime searches. ${ }^{225}$ Much depends upon the time of the search and the habits of the occupants. An evening search of a dwelling when both husband and wife are likely to be present and awake may be less alarming than a late afternoon search when only a teenager is present. Searches conducted during early morning hours are, of course, quite different. But experience in Michigan since it discarded the daytime limitation did not suggest, to the Committee's knowledge, any pattern of abusive use of early morning searches. Moreover, searches conducted at that time usually have followed an arrest of the occupants. The police might still make an early morning entry for the purpose of making an arrest, even if the nighttime search warrants could not be obtained. Prohibiting nighttime searches might thus result only in encouraging a search without a warrant, contrary to the Committee's basic objective in drafting the search warrant provisions.

\section{Execution Provisions}

Execution of searches was a primary Committee concern apart from the amendments needed to facilitate the use of search warrants. Current execution provisions are notably deficient in their failure to deal with warrantless searches. The interests of privacy and effective law enforcement considered in fashioning appropriate execution standards relate to all searches, and the same standards generally should apply to searches with and without warrants. Admittedly, the search warrant process requires certain special execution procedures (e.g., warrant service), but most of the problems of execution relate equally to both types of searches. Moreover, these problems appear to be fairly susceptible to legislative solution. ${ }^{228}$ While the Constitution does impose some limitations upon the manner of execution, those

225. Compare ALI CoDE, supra note 5, at 175; Gooding v. United States, 416 U.S. 430, 464-65 (1974) (Marshall, J., dissenting) (suggesting possible constitutional requircment of "greater justification" for a nighttime search).

226. The Committee appreciated that, from the viewpoint of the occupant of the premises, the manner of execution is often far more important than the strength of the justification for the search. Cf. Strauss, Field Interrogation: Court Rule and Police Response, $49 \mathrm{~J}$. URBAN L. 767, 770 (1970). People may be far more upset by a lawful search executed in a rude or threatening manner than by a search lacking probable cause but conducted in a polite, low-key, and unobtrusive manner. Of course, some of the most significant aspects of execution from the occupant's viewpoint relate to matters of general demeanor that are not susceptible to legislative regulation. Yet, matters of notification, distribution of receipts, and the return of property are also important, and they have traditionally been regulated by legislation, at least with respect to searches under a warrant. 
limits are fairly clear. The Committee foresaw far less difficulty in dealing with constitutional standards in this area than in dealing with the shifting standards that determine the permissible scope of warrantless searches.

The proposed provisions relating to the execution of searches concentrate upon four areas: notification of authority to search, use of force, provision of receipts for seized property, and custody and disposition of seized property. In each area the Committee sought to achieve three goals: ( 1 ) to eliminate functional inconsistencies in the current law; (2) to reduce confusion in the governing standards by eliminating ambiguities and treating significant problems not mentioned in current provisions; and (3) to provide sufficient flexibility in permissible procedures to meet emergency situations while retaining appropriate safeguards against abusive practices.

\section{A. Notification of Authority}

Section 780.656 of the current Code is a typical codification of the English common law rule on notification.227 The proposed sections on notification, sections 10,11 , and 18, vary from that provision in several respects.

First, sections 10,11, and 18 concentrate upon the need for notification of authority without regard to method of entry. Section 780.656 presently requires notification only as a prerequisite to forcible entry. Notification, however, serves interests other than possible avoidance of breaking doors or windows. An unannounced entry in any form constitutes an invasion of privacy. It tends to be frightening and disruptive, and often increases the potential for violent response. These qualities are present even though entry is gained without use of force, as by climbing through an open window. Courts in other jurisdictions have recognized this potential in their interpretations of provisions almost identical to section 780.656, and have held, for example, that the statutory notice requirement applies to any "unannounced intrusion into a dwelling ... whether officers break down a door, force open a chain lock

227. Mich. Comp. LAws ANN. \& 780.656 (1968) provides: "The officer to whom a warrant is directed, or any person assisting him, may break any outer or inner door or window of a house or building, or anything therein, in order to execute the warrant, if, after notice of his authority and purpose, he is refused admittance, or when necessary to liberate himself or any person assisting him in execution of the warrant."

Mrch. Comp. LAws ANN. $\S 780.656$ (1968) is quite similar to the federal statute on execution of warrants, 18 U.S.C. $\$ 3109$ (1970). Similar provisions are found in over one half of the states. See Blakey, The Rule of Announcement and Unlawful Entry: Miller v. United States and Ker v. California, 112 U. PA. L. Rev. 499, 508, 560-61 (1964). For a review of the English common law heritage of these provisions, see Ker $v$. California, 374 U.S. 23, 47-52 (1963) (Brennan, J., dissenting); Blakey, supra, at 500-08. 
on a partially open door, open a locked door by use of a passkey, or . . . open a closed but unlocked door."228 The Committee's proposal, like other recent revisions, approaches the problem directly rather than through an expansive interpretation of phrases such as "break" or "force."229 Sections 10, 11, and 18 apply to all forms of entry and require prior notice of authority except under specified circumstances. 230

Second, the proposed sections vary from the current law with respect to the structures included. Section 780.656 extends to entry into all buildings, including those open to the public. Sections 10, 11 , and 18, on the other hand, are limited to entry into "private buildings," as defined in section $1(a)$. When the focus is shifted from the use of force to the need for prior notification, there is no reason to include the public building, which any person can enter without announcement of identity or purpose. ${ }^{231}$ On the other

228. Sabbath v. United States, 391 U.S. 585, 590 (1968). See also People v. Rosales, 68 Cal. 2d 299, 437 P.2d 489, 66 Cal. Rptr. 1 (1968); State v. Monteith, 4 Ore. App. 90, 477 P.2d 224 (1970); State v. Miller, 7 Wash. App. 414, 499 P.2d 241 (1972).

229. See also N.Y. CRIM. P. LAw $\$ 690.50$ (McKinney 1971); ALI CoDe, supra note 5, \& SS 220.3(2). But compare former D.C. CoDE \& 23-591 (repealed 1974). The former D.C. Code required notice prior to "breaking and entry," but defined "breaking and entry" as including "any use of physical force or violence or other unauthorized entry," not including "entry obtained by trick or strategem." This standard apparently permitted entry without notification when the officer gained entry by misrepresenting his identity (e.g., by stating that he was a telephone repairman). See United States v. Phillips, 497 F.2d 1131, 1134 (9th Cir. 1974) (discussing various federal "ruse entry" cases). While entry obtained by trick does not carry with it all of the pernicious qualities of unannounced intrusions obtained by force or stealth, it may often present some of those qualities. Accordingly, entry by trick for the purpose of conducting a search should be permitted only where there is some justification for failing to give prior notice-that is, when the circumstances noted in proposed sections 10 or 18[3] are present. Of course, entry for other purposes is not governed by this requirement. See, e.g., Lewis v. United States, 385 U.S. 206 (1966) (undercover agent used ruse to enter premises to "set-up" unlawful transaction).

230. Decisions interpreting Mrck. CoMr. Laws ANN. \& 780.656 (1968), and a counterpart provision relating to arrests, MICH. CoMp. LAws ANN. \& 764.21 (1968), have held that the notice must be appropriate to the circumstances-for example, where the officer announces "this is the police" and nobody responds, his subsequent entry is not invalid because he failed to state also that his purpose was to conduct a search. See People v. Doane, 33 Mich. App. 579, 190 N.W.2d 259 (1971), revd. on other grounds, 387 Mich. 608, 198 N.W.2d 292 (1972). See also People v. Harvey, 38 Mich. App. 39, 195 N.W.2d 773 (1972). This policy has been followed in the proposed provisions. Sections 11 and 18 require that notice be given in an "appropriate manner." In light of the flexibility provided by that phrase, the Committee concluded that there was no need for additional provisions on the form of the notice, such as a provision stating that a reasonable effort to give notice will be adequate when notice is interrupted or that the announcement must be made in a voice sufficiently loud to be heard within. Cf. N.Y. Crum. P. LAW \& 690.50(1) (McKinney 1971).

231. This is not to suggest that an officer with a warrant authorizing the search of a public area in a public building (e.g., a store) should not give notice to a person in apparent control prior to undertaking the search. However, there is no need to give notice prior to entry into the building. See, e.g., ALI CoDE, supra note 5, \& 120.6 
hand, there is a need to include all private structures in which the occupant has an expectation of privacy. The New York provision accordingly includes entry into vehicles as well as buildings. ${ }^{232}$ The Committee, however, viewed notification of authority as unnecessary in the typical vehicle search. When the officer stops or approaches the automobile, his status ordinarily will be known immediately to any occupants. ${ }^{233}$

Third, sections 10,11 , and 18 depart from section 780.656 by extending the basic notification requirement to warrantless searches. ${ }^{234}$ In most instances, exigent circumstances that justify a warrantless search of a building would probably also justify entry without prior notice under the standards specified in section 18[3].235 There may be situations, however, in which a warrantless search is permissible, but in which there is no such emergency as would justify an unannounced entry. The ALI Code apparently assumes that such situations are very unlikely to occur since it does not extend its notification provision to warrantless searches. ${ }^{238}$ That assumption is tied to an ALI provision that permits entry into a building to conduct a warrantless search only if there is reasonable cause to believe that the building contains individuals in "imminent danger," things "imminently likely to burn, [or] explode," or things that will cause or be used to cause serious bodily harm if their seizure is delayed. ${ }^{237}$ The ALI rejected as constitutionally impermissible a broader pro-

(requiring demand to enter upon "private premises" to make an arrest). Compare id. $\S$ SS 220.3 (requiring notice prior to entering upon any "premises" specified in the warrant).

232. N.Y. CRIM. P. LAW $\$ 690.50$ (MCKinney 1971).

233. Even when the offcer is not wearing a uniform, he will ordinarily announce his status when stopping the automobile. Also, under the Committee proposal on arrests, he must announce his identity in making the arrest, which will usually precede the search of the vehicle. With respect to those vehicles from which occupants are not as likely to be looking outside (e.g., stationary mobile homes), see the discussion of the definition of "building" (proposed section I(a)) at text following note 240 infra.

234. The reference here is to entry to conduct a warrantless search apart from any search incident to an arrest. A separate provision in the Committee proposal on arrests requires notification prior to entry into private premises to make an arrest. See text at notes 267-68 infra.

235. See, e.g., Wayne v. United States, 318 F.2d 205, 212-13 (D.C. Cir.), cert. denied, 375 U.S. 860 (1963) (search for mortally injured person); People v. Superior Court, 6 Cal, App. 3d 421, 85 Cal. Rptr. 803 (1970) (search for bomb). Cf. Warden v. Hayden, 387 U.S. 294 (1967). But compare United States v. Rubin, 474 F.2d 262 (3d Cir, 1973).

236. See ALI CoDE, supra note 5, \$§ SS 220.3, 260.1-.6. Where the warrantless search is made incident to an arrest, see id. $\S$ SS 230.5 (quoted in note 100 supra), notification would be required pursuant to $i d$. $\S 120.6$, governing entry of private premises to make an arrest.

237. See id. \& SS 260.5. See also note 270 infra. 
vision that would have permitted entry generally where officers have probable cause to believe that the building contains seizable things in imminent danger of being moved or destroyed. ${ }^{238}$ On the other hand, the Project on Law Enforcement includes such a provision. ${ }^{230}$ The Committee found no need to determine whether the ALI or PLE proposal more accurately reflects the scope of the exigent circumstances doctrine. Even under the ALI provision, there may be instances, for example, where the danger of explosion or fire is not so "imminent" as to justify an unannounced entry, even though it does justify entry to conduct a warrantless search for incendiary items. ${ }^{240}$ Furthermore, the Committee's draft, unlike the ALI Code, defines "building" to include mobile homes and similar vehicles. While these "buildings" may be sufficiently mobile to justify a warrantless search under Chambers and Coolidge, that mobility ordinarily would not be sufficient to justify dispensing with the notice requirement under section 18[3].

Finally, sections 10, 11, and 18 make their greatest departure from current law in recognizing certain exceptions to the notice requirement. Section 780.656 does not refer to any exceptional circumstances under which an officer may make a forcible entry without giving prior notice of his authority and purpose. Many states with similar statutes have recognized certain common law exceptions, however. ${ }^{241}$ Those exceptions, as they apply to entry for the purpose of a search, are commonly described as: (1) the physical peril exception-where the giving of notice is likely to result in imminent peril of bodily harm to the persons executing the search or other persons on the premises; (2) the useless gesture exception -where the persons within already know of the officer's authority and purpose; (3) the unoccupied premises exception-where the officer reasonably believes that the premises are currently unoccupied; and (4) the destruction of evidence exception-where provid-

238. See ALI CoDE, supra note 5, at 210-11. Compare id. \& SS 230.5, quoted in note 100 supra, permitting extension of a search incident to an arrest to the premises when there is a similar likelihood of losing evidence. See also id. §SS 260.3, authorizing certain vehicular searches without warrants.

239. PLE WarRantLess SeARChes, supta note 82, Rule 502. See also United States v. Rubin, 474 F.2d 262 (3d Cir. 1973).

240. Cf. People v. White, 54 Mich. App. 342, 220 N.W.2d 789 (1974) (involving a search for booby-trapped evidence).

241. See, e.g., State v. Mendoza, 104 Ariz. 395, 454 P.2d 140 (1969); People v. Dumas, 9 Cal. 3d 871, 512 P.2d 1208, 109 Cal. Rptr. 304 (1973); State v. Gassner, 6 Ore. App. 452, 488 P.2d 822 (1971). Over one half of the states have recognized one or more of these "common law" exceptions either by court decision or by specific "no-knock" provisions in statutes prescribing notice requirements. See H.R. REP. No. 91-907, 91st Cong., 2d Sess, 104 (1970) [hereinafter HousE RERORT]. 
ing notice is likely to result in the destruction of seizable property. ${ }^{242}$ In Ker v. California, ${ }^{243}$ the Supreme Court, although dealing with entry to make an arrest, apparently accepted the constitutionality of these exceptions if properly applied. ${ }^{244}$ Relying upon Ker, several jurisdictions have adopted statutory provisions that specifically recognize one or more of the exceptions. ${ }^{245}$

The Committee's proposal recognizes only the physical peril and destruction of evidence exceptions. ${ }^{246}$ The Committee concluded that the exception for unoccupied premises was unnecessary. The slight delay involved in giving notice and waiting a reasonable time for a response is a worthwhile investment in avoiding a possible unannounced entry based upon an erroneous belief that the premises are vacant. The same policy also led the Committee to reject the "useless gesture" exception. Many useless gesture cases involve situations in which the subject sees the officer coming, races into the house, and bolts the door. In such a case, prompt entry following notice is permitted under proposed section $11[3](c)$-reasonable be-

242. Although the first and fourth exceptions are commonly stated in terms of the consequences of giving notice, cases applying these exceptions consider the consequences of the delay occasioned both by giving notice and by waiting a reasonable period to determine if entry will be denied. See, e.g., United States ex rel. Menduchi v. Tracy, 350 F.2d 658, 662 (3d Cir. 1965); Henson v. State, 236 Md. 518, 523, 204 A.2d 516, 519 (1964). See also Note, Announcement in Police Entries, 80 Yale L.J. 139, 151 (1970). Cf. State v. Lindes, 291 Minn. 217, 190 N.W.2d 91 (1971). Since it is the notice that creates the dangerous potential of the waiting period, section 10 follows the traditional statutory form in referring only to the impact of giving notice.

243. 374 U.S. 23 (1963).

244. The four exceptions appear to be consistent in principle with both Justice Clark's plurality opinion and Justice Brennan's separate opinon, although the latter opinion suggests a somewhat narrower standard as to the destruction of evidence. See Note, supra note 242, at 148; note 270 infra. It should be noted that Justice Brennan was referring throughout Ker to unannounced entry based on the officer's own determination of need. More leeway might be granted when entry without prior notice is authorized by a court order. Cf. United States v. Ventresca, 380 U.S. 102 (1965).

245. See, e.g., N.Y. CRIM. P. LAW $\$ 690.35-.50$ (McKinney 1971); N.D. CEnT. Code § 29-29-08 (1973); UTAH CODE ANN. § 77-54-9 (Supp. 1973).

246. The Committee's decision to authorize no-knock entry under limited circumstances was made prior to the repeal of the federal no-knock provisions. See Act of Oct. 26, 1974, Pub. L. No. 93-481. The Committee was aware, however, of the difficulties experienced in federal no-knock "raids" in connection with narcotics investigations. Although some question was raised as to the value of no-knock entry as an enforcement tool, cf. Senate, House Vote To Repeal Federal No-Knock Authority, 15 CrIM. L. REP. 2460 (August 28, 1974), a majority of the Committee was convinced that experience in Michigan and other jurisdictions established a need for no-knock authorization under appropriate circumstances. Several members emphasized that if no exception to the notification requirement were recognized, executing officers would not only be barred from making entry without prior notification, but also from giving notice and entering immediately thereafter without waiting for a response (a more common practice in some of the situations noted below). See note 242 supra and the discussion of "entry without consent" in text at note 272 infra. 
lief exists that prompt admission will be denied-and the minimal effort involved in giving appropriate notice immediately prior to entry is unlikely to frustrate the officer in preventing the possible destruction of evidence. ${ }^{247}$ On the other hand, there are so-called "useless gesture" cases in which the officer only suspects that his presence is known (e.g., someone appears to be looking out the window) or in which the officer believes that notice will not be heard (e.g., the occupant appears to be sleeping). ${ }^{248}$ In such cases, assuming there is no ground for fearing physical peril, the officer should not be allowed to rest simply upon his possibly erroneous assumption that announcement of his authority and purpose would be a useless gesture. Indeed, an announcement in those circumstances might be required constitutionally in light of the suggestion in Miller $v$. United States 249 that the "useless gesture" exception applies only when "the facts known to [the] officers would justify them in being virtually certain that the petitioner already knows their purpose."250

The Committee had comparatively little difficulty in accepting a "physical peril" exception based upon a reasonable-cause standard. While some Committee members generally opposed any no-knock provision, they recognized that where an unannounced entry is reasonably believed necessary to avoid physical peril to the executing officer or to another, the officer simply cannot be expected to give notice or to delay his entry to await possible admittance. ${ }^{251}$ The Committee sought to prevent abuse of this authority by requiring advance approval of a magistrate when the officer is operating pursuant to a warrant and the grounds justifying an unannounced entry are known at the time of the warrant application. ${ }^{262}$ While decisions

247. Of course, if the individual's prior response to the appearance of the officer suggests possible physical peril, then section $11[2]$ (b) would permit the officer to enter without giving notice.

248. See, e.g., Bosley v. United States, 426 F.2d 1257 (D.C. Gir. 1970).

249. 357 U.S. 301 (1958).

250. 357 U.S. at 310 (emphasis added).

251. Some support for this view was found in Mrch. Comp. LAws ANN. \& 780.656 (1968), which permits immediate use of force by the officer "when necessary to liberate himself or any other person assisting him in the execution of the warrant" (cmphasis added). However, this provision apparently refers to persons within a place who seck to escape, and therefore does not necessarily support a provision authorizing the usc of force where the danger could be avoided by simply not seeking entry in the first place.

252. See proposed sections 10(b), 11[2](b). State statutes recognizing exceptions to the notification requirement ordinarily include provisions permitting warrant authorization of no-knock entry. See, e.g., statutes cited note 245 supra. Judicial decisions have also recognized warrant authorization of no-knock entry in the absence of a statutory provision. See State v. Parker, 283 Minn. 127, 166 N.W.2d 347 (1969). Compare ALI CODE, supra note 5, § SS 220.3, described in note 260 infra. 
indicate that reasonable cause to anticipate physical peril must exist at the time of entry, ${ }^{253}$ there may be cases in which factors known at the time of the warrant issuance clearly indicate that danger will exist when entry is made. ${ }^{254}$ Of course, the requisite reasonable cause must consist of more than the fact that the occupant possesses a weapon; the officers also must show a reasonable basis for assuming that the occupant is likely to use it. 255 The Committee proposal encourages the officer to present such a case to the magistrate, because otherwise the officer can rely only upon circumstances unknown at the time of the warrant application in subsequently justifying his unannounced entry. ${ }^{256}$

While the potential source of danger may disappear subsequent to a magisterial authorization of entry without notice, that possibility does not justify refusing to permit advance authorization of entry without notice. A similar potential for changed circumstances is present with respect to all aspects of warrant authority, including the existence of probable cause. ${ }^{257}$ It is assumed that police will not

253. See Ker v. California, 374 U.S. 23 (1963); Parsley v. Superior Court, 9 Cal. 3d 934, 513 P.2d 611, 109 Cal. Rptr. 563 (1973). (1973).

254. See, e.g., People v. Dumas, 9 Cal. 3d 871, 512 P.2d 1208, 109 Cal. Rptr. 304

255. See People v. Dumas, 9 Cal. 3d 871, 512 P.2d 1208, 109 Cal. Rptr. 304 (1973). ALI CODE, supra note 5 , at 177 , states that the crucial issue in the issuance of "no-knock authority" is whether dispensing with notice will increase or decrease the risk "of executing the warrant with 'all practicable safety ...." This suggests that the court must weigh the risk involved in entry without notice against the risk involved in entry with notice. The Committee concluded, however, that once it is shown that reasonable cause exists to believe that an occupant will respond to notice with physical force, the court should not be placed in the position of determining whether entry without notice will improve the officer's chances of avoiding injury. There may be some situations presenting a threat of resistance in which notice nevertheless might not increase the risk (e.g., where an announced entry is likely to provoke a dangerous response from only one of several persons who may be on the premises, while the others are more likely to respond violently to an unannounced entry). That determination, however, should be left to the officer, who is in a better position to evaluate what mode of entry will minimize the risk in a particular case. The court's role under section 10(b) is only to ensure that the officer is reasonable in concluding that a real risk exists.

256. See section 11[2](b). Although a similar limitation is not imposed upon warrantless searches, this distinction was not viewed as likely, in itself, to discourage applications for warrants. See text at notes 238-40 supra on the fourth amendment limitations upon warrantless searches of buildings.

257. While the proposed provisions do not state specifically that an officer should decline to execute a warrant when aware of changed circumstances that eliminate probable cause, proposed section 14[2] is premised, in part, on the existence of such an obligation. Cf. ALI CoDE, supra note 5, § 120.9. A similar obligation would exist with respect to use of no-knock authority granted in the warrant. In other settings the existence of probable cause at the time the warrant was issued has not precluded a challenge to the exercise of warrant authority after probable cause clearly has dissipated. See, e.g., Commonwealth v. McCants, 450 Pa. 245, 299 A.2d 283 (1973) (substantial delay in executing warrant renders it "lifeless"). Cf. People v. Siemieniec, 368 
use no-knock authorization when it becomes obvious at the scene that the grounds for the authorization no longer exist. In any event, the possibility that police may use such authority without regard to changed circumstances is offset by the value of obtaining advance judicial review in the vast majority of cases in which circumstances will not have changed. ${ }^{258}$

The Committee had greater difficulty with the "destruction of evidence" exception. Reports of abusive no-knock entries in other jurisdictions have concerned entries based primarily on this ground. ${ }^{259}$ The Committee concluded that the potential for misapplication of a destruction of evidence exception is so great that the exception should be recognized only when approved in advance by a magistrate. A similar approach has been adopted in New York, 200 but the standard for authorization there arguably is so broad as to encompass all cases in which the item to be seized is susceptible to swift destruction. ${ }^{201}$ Section 10(a), on the other hand, assesses the possible loss of evidence in the particular case. The nature of the item to be seized is, of course, an important factor. But other factors should also be considered, including the past behavior of the suspect, the nature of the criminal activity, ${ }^{262}$ and the likely location of the

Mich. 405, 118 N.W.2d 430 (1962); People v. Wright, 367 Mich. 611, 116 N.W.2d 786 (1962).

258. See also PLE SEARch WARRANT ExEcution, supra note 215, at 36:

The California Supreme Court recently ... [held] that the "key to permissible unannounced entry" is the search team's knowledge of exigent circumstances at the time of entry, and that a "warrant authorizing such action adds nothing." [Parsley v. Superior Court, 9 Cal. 3d 934, 513 P.2d 611, 109 Cal. Rptr. 563 (1973)].

Nevertheless, the drafters feel that judicial authorization should be sought even if it is legally meaningless. Seeking approval supports the conclusion that exigent circumstances do exist and are not the product of a creative imagination. Seeking approval demonstrates good faith, since the search team is asking a neutral, detached magistrate to test its possibly hurried or unreasonable conclusion.

259. See N.Y. Times, June 25, 1973, at 1, col. 5 (late city ed.); Percy, The No.Knock Law: An Indelicate Balance, 10 TrIAL, March-April 1974, at 29.

260. See N.Y. CRrM. P. LAw \& 690.50[2](b) (McKinney 1971). Compare State v. Linder, 291 Minn. 217, 190 N.W.2d 91 (1971); former D.C. CoDE \& 23-591(c)(2)(A) (repealed 1974) (permitting no-knock entry to prevent destruction of evidence when authorized by warrant or upon facts unknown at the time warrant was obtained); ALI CODE, supra note 5, § SS 220.3(3) (no provision for warrant authorization of no-knock entry, but executing officer may make such entry without authorization if he has "reasonable cause to believe that the notice... would endanger the successful execution of the warrant with all practicable safety").

261. N.X. CrIM. P. LAW \& 690.35 (McKinney 1971) applies whenever "the property sought may be easily and quickly destroyed or disposed of."

262. See, e.g., House REPORT, supra note 241, at 108-09:

IIlegal gambling and bookmaking operations have taken special precautions so that they will be able to destroy the work product of the gambling operations during the time the officer has to wait before breaking into the premises. In 1962, for example, it was reported that less than 30 seconds were necessary to destroy all of the evidence of a wire service headquarters. 
evidence. Thus, a search for narcotics would not inevitably justify an unannounced entry. ${ }^{263}$ The magistrate would also consider such factors as the likely means of quickly disposing of the narcotics, the police capacity to observe the activity of the occupants following an announcement, and the nature of the narcotics activity involved. The requirement of a case-by-case analysis, combined with prior judicial authorization, should substantially restrict the potential for abuse of no-knock authority based on likely destruction of evidence. ${ }^{264}$

Of course, a potential cost of the Committee's proposal is the possible destruction of evidence when police are unable to utilize no-knock authority because either ( 1 ) entry is made without a warrant, or (2) entry is made with a warrant that fails to authorize noknock entry because the police did not learn of circumstances suggesting likely destruction of evidence until they arrived at the scene to execute the warrant. The risk in either situation, however, is not very great. As previously noted, ${ }^{205}$ entry of a private building to conduct a warrantless search (apart from an arrest) will only rarely be permissible. Moreover, those exigent circumstances that might justify entry to conduct a warrantless search often would include potential physical peril that justifies no-knock entry without regard to the destruction of evidence. ${ }^{266}$ More significant will be cases in which police enter a private building to make a warrantless arrest. ${ }^{287}$ The officer may reasonably fear that the person to be arrested will respond to a request to enter by destroying any evidence in his possession. While unannounced entry would not be permissible under section 11, a separate provision in the Committee's proposal on arrests would permit no-knock entry to make a warrantless arrest if the officer has reasonable cause to believe that the person will flee. ${ }^{268}$ This provi-

Experience has shown that numbers bets are recorded on either "flash" paper which ignites on contact with fire or "water soluble" paper which dissolves on contact with water, and that the time spent by the executing officer in giving notice and waiting to be refused admittance is used by the gambler to destroy his work product. [Footnote omitted.]

263. Compare the decisions discussed in State v. Gassner, 6 Ore. App. 452, 488 P.2d 822, 826-28 (1971).

264. The requirement of warrant authorization will also facilitate police imposition of a requirement of approval by superior officers and compliance with specific internal regulations relating to no-knock entry (e.g., wearing of uniforms, double-checking addresses). See, e.g., N.Y. Times, July 17, 1973, at 13, col. 1 (late city ed.) (describing Federal Drug Enforcement Administration policy statement).

265. See text at notes 235-40 supra.

266. See cases cited note 235 supra.

267. See text at note 188 supra.

268. Proposed section 118[2] (to be submitted to the State Bar Commissioners in a 
sion would cover many of the situations likely to involve destruction of evidence. Also, in some cases the officer will have ample time to obtain a search warrant authorizing no-knock entry before he makes the arrest. 269

The second situation noted above-in which a search warrant is obtained but the possibility of destruction of evidence is subsequently discovered at the scene of the search-is more appropriately treated by authorizing immediate entry after notification than by expanding no-knock entry. In most such situations the information suggesting likely destruction of evidence is obtained only after the police make their presence known. Once the police knock, sounds from within may suggest that the occupants are moving away from the door. ${ }^{270}$ Immediate entry is then permitted pursuant to section 11[3] if the response to the officer's announcement indicates denial of a reasonably prompt entry or potential physical peril. ${ }^{271}$ Section 11[3] admittedly would not cover all situations in which the response to the officer's announcement might suggest the possible destruction of evidence. A sound of a flushing toilet, for example, does not indicate a refusal to permit prompt entry or potential physical peril, although it may signify the destruction of evidence. But to permit immediate entry based upon such a sound would undermine the basic premise of section 10: that such factors are too readily misinterpreted in the process of execution, and therefore an

forthcoming publication). The New York arrest provisions provide similar authority. However, they also permit the officer to enter without giving prior notice when there is reasonable cause to believe that "the giving of such notice will ... [r]esult in the destruction, damaging or secretion of material evidence." See N.Y. CrIM. P. LAW $\$ \S 120.80(4)$ (c), 140.15(4) (McKinney 1971). Compare the New York search warrant provision, N.Y. CRIM. P. LAW § 690.50[2](b) (Mckinney 1971), noted in text at note 260 supra.

269. Cf. United States v. Brown, 467 F.2d 419 (D.C. Cir. 1972), discussed in note 191 supra; People v. Eddington, 23 Mich. App. 210, 178 N.W.2d 686 (1970), affd., 387 Mich. 551, 198 N.W.2d 297 (1972).

270. Thus, Justice Brennan, in Ker, described the destruction of evidence exception to the announcement rule as follows: "[T] unannounced police intrusion into a private home, with or without an arrest warrant, except ... where those within, made aware of the presence of someone outside (because, for example, there has been a knock at the door), are then engaged in activity which justifies the officers in the belief that ... the destruction of evidence is being attempted." Ker v. Galifornia, 374 U.S. 23, 47 (separate opinion). See also Statc v. Linder, 291 Minn. 217, 190 N.W.2d 91 (1971).

271. This provision is limited to cases involving a response. Where there is no response, the officer must wait a reasonable time. Immediate entry on the grounds noted in section 11[3](c) probably would also be permitted under current interpretations of Mrch. Comp. LAws Ann. \& 780.656 (1968). See People v. Brown, 43 Mich. App. 74, 202 N.W.2d 493 (1972) (forcible entry permitted after offcer announced, "it's the police" and heard a noise indicating that someone was running to the rear of the apartment). 
exception based upon destruction of evidence should be recognized only upon magisterial authorization.

\section{B. Entry Without Consent}

Section 11[3], governing entry into a building to conduct a search, further reflects the policy of the notification provisions. First, it requires that entry be delayed following notification of authority until admittance is denied, either formally or through action or inaction indicating that the officer will not be admitted with reasonable promptness. ${ }^{272}$ Unlike the current statutes, proposed section 11[3] applies to all forms of entry without consent, and not just to entry by breaking doors or windows. Second, section 11[3](a) specifically permits immediate entry whenever section 11[2] applies, that is, where no-knock entry is permitted because of danger of physical peril or warrant authorization. Section 11[3] thus recognizes that the authority to make a no-knock entry necessarily includes the authority to knock, give notice, and enter immediately without waiting for a response (a practice that is often preferred to a true no-knock entry).

\section{Use of Force}

Proposed section 19 prescribes the appropriate use of force against both person and property in the execution of a search. In its treatment of force against property, section 19 departs most fundamentally from present law by separating the use of force from notification and entry requirements. ${ }^{273}$ As noted above, the need for prior notification is not limited to cases of forcible entry. ${ }^{274}$ Similarly, avoidance of unnecessary force is desirable not only in cases in which the officer enters without prior notification. The disruptive impact of a no-knock entry obviously increases with the use of force, both in terms of the damage to property and the threatening nature of the entry. The same disruptive impact may also exist, albeit to a lesser extent, when unnecessary force is used following a proper request for admittance. For example, if the officer receives no response to his request, and breaks through a window when entry could have been made as quickly and safely by opening an unlocked door, he unnecessarily damages property and excessively threatens

272. A similar requirement is imposed under Mrch. CoMp. LAws ANN. § 780.656 (1968). See also People v. Doane, 33 Mich. App. 579, 190 N.W.2d 259 (1971), revd. on other grounds, 387 Mich. 608, 195 N.W.2d 773 (1972) (noting that "refusal of admittance" under the current statute is "not limited to affirmative denials").

273. Compare Mich. Comp. LAws ANN. § 780.656 (1968).

274. See text at notes 227-30 supra. 
any occupants. ${ }^{275}$ The situation is roughly parallel to that presented in the arrest area, where the use of excessive force is prohibited without regard to whether the arrest is justified by probable cause. Section 19 similarly prohibits the use of excessive force whether or not the entry is otherwise lawful. In many cases, those circumstances that allow entry without consent may also suggest that force is needed to achieve a safe entry, but the statute should not automatically authorize force whenever entry without consent is permissible under section 11[3].

Section 19 permits that degree of force against property "reasonably necessary" successfully to execute the search. The same standard has traditionally been employed to describe the degree of nondeadly force that an officer may use against a person in making an arrest. The standard has not caused serious administrative problems in the arrest area and there is no reason to anticipate any difficulty in its application under section 19, especially since courts are likely to give officers more leeway in the use of force against property than against the person. Several states employ a similar standard in provisions governing forcible entry. ${ }^{276}$

In its treatment of force against the person, section 19 fills a gap in the law. Neither the current procedural code nor the substantive criminal code deals with an officer's use of force against a person who physically obstructs a search. Under section 19 the

275. Although the absence of a response suggests that the premises are vacant, the officer still should make a reasonable effort to enter in a manner that would not unduly frighten an occupant who may have failed to hear the doorbell. Of course, where the officer believes that an occupant is lying in wait, safety considerations might require "entry through a window even though an unlocked door is available. See generally PLE SEARch WARRANT ExEcution, supra note 215, Rules 207(B) (suggesting that officers entering vacant premises initially "should determine whether a key to the premises is readily available"), 206 ("entry should be conducted in as courteous and non-destructive a manner as is practicable," and "[f]irearms should not be exhibited ... unless the lead investigator ... reasonably feels the team is endangered").

276. See, e.g., Ill. Rev. Stat. ch. 38, § 108-8 (1974) ("all necessary and reasonable force"); KAn. Stat. ANN. § 22-2508 (Supp. 1973) (same). Cf. Wis. Stat. ANN. § 968.14 (1971) ("all necessary force"). Section 19, of course, is not limited to forcible entry into buildings, but applies to other uses of force in conducting a search.

The ALI commentary, while supporting a "reasonable and necessary" standard, urges that the provision also refer to "the factors against which 'reasonableness' and "necessity" are to be weighed"-that is, "success in finding and seizing what is sought and maximum safety for all concerned." See ALI Code, supra note 5, at 178. The Committee accepted the significance of these factors but concluded that a general reference to them, such as is found in id. \& SS 220.3(7), was not necessary. Indeed, such reference could cause difficulty if the term "success" were viewed narrowly as relating only to the possible loss or destruction of the particular matter to be seized. For example, a forcible entry may be needed, even though the matter could be scized later when entry might be possible without force, because prompt seizure is necessary to locate a key suspect who is likely to flee the jurisdiction. Cf. PLE SEArch Warrant Executron, supra note 215, Rule 207(A)(2). 
officer may use nondeadly force if reasonably believed necessary to execute the search, but he may not use deadly force unless he "reasonably believes such force to be necessary to defend ... [against] the use or imminent use of deadly physical force." Although section 19 apparently states the prevailing rule in this country, ${ }^{277}$ Michigan has no opinions on point. ${ }^{278}$ If the force that can be used to execute a search is analogous to that permissible in arresting a person for obstructing the search, section 19 would probably reflect the current Michigan law. Since the obstruction would most likely be a misdemeanor, ${ }^{279}$ the arresting officer could use only nondeadly force in the absence of a threat justifying the use of deadly force in self-defense. ${ }^{280}$ If, however, the permissible degree of force in executing a search is analogous to that permissible in making an arrest for the offense being investigated through the search, then section 19 might provide less leeway in the use of deadly force where the search relates to a felony. At least in some circumstances, deadly force may be used to secure the arrest of a suspected felon even though the felon is not threatening the imminent use of deadly force. ${ }^{281}$ Current authorization for the use of deadly force in arrest situations, however, emerges largely from the premise that the felon presents a potential future threat and therefore must immediately be taken into custody. ${ }^{282}$ The evidence of a felony that an obstructive person is preventing from being seized presumably would not have this quality. 283

277. See, e.g., N.Y. CRIM. P. LAW, § 690.50(1) (McKinney 1971); ALI CoDE, supra note 5, § SS 220.3(7).

278. It was the consensus of the Committee that the section 19 standard should not be left to extrapolation from arrest decisions, but should be set forth clearly in the proposed revision. Some Committee members were opposed, however, to including either this standard or the standard as to the use of force against property. They argued that these provisions related primarily to the imposition of tort liability for damage to the property or person, and that such damage may be distinguished from the privacy interest protected by the general limitations upon searches.

279. See Mrch. Comp. LAws ANN. \& 750.479 (1968).

280. See Comment, Justifiable Force in Property Defense and Arrest Under the Michigan Revised Criminal Code, 14 Wayne L. REv. 847, 853-60 (1968).

281. See Israel, The Process of Penal Law Reform, 14 WAYNe L. REv. 772, 828 (1968). 282. Id.

283. ALI CoDE, supra note 5, § SS 220.3(7) provides: "The use of deadly force in the execution of a search warrant, other than in self-defense or defense of others, is justifiable only if the executing officer reasonably believes that there is a substantial risk that the individuals or things to be seized will .... cause or be used to cause death or serious bodily harm if their seizure is delayed ...."

The Committee concluded that such a provision was unnecessary because the circumstances permitting use of deadly force under section SS $220.3(7)$ are adequately encompassed by section 19, and the law governing the use of deadly force in making an arrest. Where the search is directed to finding and arresting a dangerous person, 
Conceivably, a situation could arise in which police would be unable to prosecute a dangerous felon because they lacked the authority to use deadly force to prevent the destruction of crucial evidence. Thus, deadly force might be the only available means of stopping a person who has not engaged in dangerous criminal activity, but who is fleeing with evidence necessary to arrest and prosecute another person who has committed a dangerous felony. Such circumstances, however, are too rare and difficult to determine to justify creating a special exception. Moreover, in terms of the danger presented, such a situation would not differ substantially from the flight of a material witness who possesses information needed to arrest and prosecute a dangerous felon; there certainly is no suggestion in current law that deadly force could be used to restrain such a person.

\section{Receipt}

Section 780.655 of the Michigan Code requires the issuance of a receipt upon the seizure of items "under [a] . . . warrant." Proposed section 20 follows the lead of several states in requiring a receipt for items seized both with and without warrants. ${ }^{284}$ The receipt requirement serves several functions, ${ }^{285}$ none of which can appropriately be limited only to seizures made pursuant to warrants. While the receipt requirement strengthens the warrant process by assisting the recipient in determining whether to challenge the validity of the seizure, a receipt may equally assist a recipient in determining whether to challenge a seizure pursuant to a warrantless

the officer's use of deadly force against that person may appropriately be governed by the principles applicable to arrests. Similarly, even where the search is directed at finding dangerous materials, ordinarily the danger stems only from the possible use of the materials by a person at the scene whom the police are seeking to arrest. In the occasional situations in which that is not the case (e.g., where the search is directed at finding explosives that could be detonated accidently), section 19 provides appro. priate authority for the use of deadly force because there then is a need to protect a "third person"- the victim of any such accident. Police training has traditionally conditioned the use of deadly force on self-defense, the protection of others, and the arrest of dangerous felons. So long as these grounds are sufficient in practice, it would be wise to avoid the potential confusion, and possible lessening of restraint, that might result from adoption of an additional ground as stated in section SS 220.3(7).

284. See, e.g., Kan. Stat. AnN. \& 22-2512 (Supp. 1973); WIs. Stat. ANN. § 968.18 (1971). But see ALI CoDE, supra note 5, \$ SS 280.2, requiring a list to be filed with the court "[i]n all cases of seizure other than pursuant to a search warrant," with a copy given to the defendant or his counsel. In searches conducted pursuant to a warrant or consent, however, a receipt must be given to the occupant at the time of the search. Id. \& SS 220.3(6). Proposed section 20 applies to items seized in connection with searches authorized by consent, as well as to warrantless searches under sections 16 and 18 .

285. See text at notes 212-13 supra. 
search. The receipt requirement also assists the recipient in reclaiming the property seized, but that function too is suited to all searches. Admittedly, the search pursuant to a warrant is more likely to involve situations in which the occupant will find it difficult to determine what has been taken if not given a receipt. Thus, searches likely to result in the seizure of a large number of items (e.g., searches of premises allegedly used for bookmaking activities) usually are made pursuant to a warrant. On the other hand, at least one common type of warrantless search is likely to produce a similar difficulty. Post-arrest automobile searches authorized under Chambers often will occur when the driver is not present and when he no longer has ready access to the vehicle to determine what was taken. ${ }^{286}$ Thus, in terms of the functional value of the receipt, the distinction between searches with and without warrants is difficult to justify. Nor is the distinction readily supported by substantial differences in ease of administration, given the flexibility provided by proposed section 20.287

Section 20 applies solely to items subject to seizure under section 6. That section does not encompass matter seized and retained only for custodial purposes under section 17[1]. The Committee treated the custodial search in section 17 only in so far as it represents a potential method of obtaining evidentiary matter, and therefore avoided proposing extensive regulation of the custodial process. ${ }^{288}$ Where the item initially seized for custodial purposes is subsequently identified and kept as evidentiary matter, however, section 17[2] requires issuance of a receipt. Similarly, under section $16[4]$ a receipt must be issued for items seized by private persons and subsequently turned over to the police.

Section 20 requires that the receipt list all tangible things seized.

286. See text at notes $92-94$ supra.

287. Proposed section 20, unlike current section 780.655, does not require immediate issuance of the receipt when that is impracticable. While it often may not be feasible to issue a receipt immediately after making a warrantless seizure incident to an arrest, officers can comply with section 20 by preparing and delivering the receipt following the arrestee's arrival at the station. That practice should not impose an undue burden on the officer. Indeed, a similar practice is currently followed when the officer determines that the seized item need be kept only for custodial purposes and surrenders it to the jailor. Although a requirement that receipts be issued when-evidentiary items are seized incident to warrantless searches adds to the paperwork currently required of the police, the increase is not substantial because the police generally keep records of these items in one form or another.

288. The Committee anticipated, however, that receipts would continue to be provided for inventory items, as is currently the practice. Such receipts do not serve all of the same functions as the receipt for evidentiary items, and therefore might not be as extensive in coverage. Thus, inventory receipts might not list such individual items of clothing as are regularly taken. 
Most state provisions require receipts only for "property" seized.280 If the term "property" is limited to its usual meaning, the receipt requirement would not apply when the officer seizes items in which a lawful possessory interest could not be obtained. ${ }^{200}$ That limitation would substantially undermine the effectiveness of the receipt requirement in assisting the defendant in determining whether to challenge the search and seizure. ${ }^{201}$ Section 20 accordingly follows the current provision governing receipts, ${ }^{202}$ which applies to the seizure of "property or other things."

Arguably, section 20 should have been expanded to require the listing of all evidence seized pursuant to a search. As previously noted, both the Constitution and proposed section 6 treat incorporeal information obtained through a search as "seized matter."203 The Committee decided, however, that a peace officer could not reasonably be expected to list all of the relevant incorporeal information seized in connection with a search. Very frequently the officer may not be aware of the significance of the information obtained until he reviews the case in preparation for trial. Moreover, limiting the receipt requirement to the seizure of tangible things should not substantially detract from its usefulness in assisting the defendant. Where both tangible things and incorporeal information are seized, a receipt listing only the tangible things ordinarily should provide the defendant with sufficient information to consider a possible challenge to the search. Where a search results only in the seizure of incorporeal information, it will usually have been conducted via surreptitious observation that required warrant authorization, ${ }^{294}$ and the served copy of the warrant would provide the defendant with adequate notice of the search.

Presently, section 780.655 requires that the receipt be given to the person "from whose premises the property or thing was taken." This phrase might be read as referring only to a person 289. See, e.g., CAL. PEN. Code $\S 1535$ (West 1970); Kan. Stat. AnN. § 22-2512 (Supp. 1973).

290. See, e.g., State v. Cowen, 231 Iowa 1117, 3 N.W.2d 176 (1942) (gambling devices prohibited by law not property); Deeg v. Detroit, 345 Mich. 371, 76 N.W.2d 16 (1956) (no property right in corpse).

291. The Committee recognized that this function could, perhaps, be served more effectively by other means. Thus, a few jurisdictions have discovery provisions requiring that the prosecutor inform the defendant of, for example, any "relevant material and information regarding ... [s]pecified searches and seizures . . . A ALAS. R. CRIMr. P. 16(b)(6). The Committee viewed such provisions as more appropriate for its consideration in connection with the area of discovery.

292. Mich. CoMrp. LAWS ANN. § 780.655 (1968).

293. See text at notes 182-86 supra.

294. See text at notes 182-86 supra. 
with some property interest in the premises, such as an owner or a tenant, but it is viewed in practice as including any person who appears to have current possession of the premises, such as a babysitter, employee, or overnight guest. Section 20 restates this standard by requiring that the receipt be given to any person present who is in "apparent control" of the premises. If no such person appears to be present, the receipt is to be posted at the place or forwarded to the owner as appropriate under the circumstances. The "apparent control" standard, borrowed from the ALI Code, ${ }^{295}$ permits the officer to rely upon the circumstances as they reasonably appear to him. The Committee was concerned that the receipt provision not be viewed as ordinarily requiring interrogation in order to serve the receipt properly. In many instances, it may be highly incriminating to acknowledge that one is a regular occupant of the premises. The officer should not be encouraged to bypass limitations otherwise imposed upon interrogation on the ground that the information must be obtained to serve the receipt properly. The "apparent control" standard ordinarily should eliminate the need for any information beyond that observed by the officer, although there may be unusual cases in which the officer might need more information because all persons present appear to be casual visitors. The Committee rejected the alternative of permitting the officer to give the receipt to "anyone present"; that standard appeared less likely than posting to assure that a person with some interest in the premises would eventually receive the receipt, particularly where the person on the premises is arrested at the time of the search. ${ }^{296}$

\section{E. Disposition of Seized Property}

Section 21 governs the disposition of seized items. This section typifies many of the statutory revisions proposed by the Committee. In large part, it seeks simply to provide guidelines that reflect current policy and practice more accurately and appropriately than the present provisions. ${ }^{297}$ Perhaps the most significant illustration of this approach in section 21 is the establishment of a single distribution pattern governing items seized with and without a warrant. Currently, section 780.655 applies only to items seized pursuant to a warrant, but the distribution pattern established therein commonly is followed with respect to all seized property.

295. ALI CoDE, supra note 5, \& SS 220.3.

296. The same concern led the Committee to propose a new requirement in section 20 that the receipt be forwarded, rather than posted on the premises, where the premises appear regularly unoccupied.

297. See Mrch. Comp. LAws ANN. § 780.655 (1968). 
Subsection [1] deals with the initial duty to retain seized items for use in a subsequent prosecution. Like many of the Committee's proposals, it restates current standards in terms sufficiently broad to permit various practices that are consistent with the basic objective of, but arguably are inconsistent with the language of the present provision. Thus, section 780.655 states that an item seized under a warrant "shall be safely kept by the officer" who seized the property. Unless the term "kept" is interpreted very liberally, this standard is incompatible with current practice in many counties. Seized matter usually is "kept" in the physical custody of another officer of the same department or of some other responsible person. ${ }^{298}$ Section 21 permits greater flexibility by requiring only that the officer seizing the item "cause" it to be kept safely. ${ }^{200}$ Similarly, the current provision unduly restricts the prosecution in permitting the item seized to be kept only "so long as necessary for the purpose of being produced or used as evidence in any trial." The term "trial" may not be sufficiently broad to include all stages of a criminal proceeding at which there may be a need to produce seized matter (e.g., a sentencing hearing). Furthermore, seized matter occasionally may be needed for prosecution purposes other than "being produced or used as evidence" (e.g., to refresh a witness" memory prior to testifying). Section 21 accordingly directs that the material be kept "so long as necessary for use in a criminal prosecution."

Subsection [2] of section 21 also reflects current practice, but seeks to provide more satisfactory guidelines by placing that practice in a more appropriate administrative setting. Subsection [2] authorizes, under limited circumstances, the temporary release of a seized item pending its use in a forthcoming prosecution. Read literally, current section 780.655 would seem to bar any such release by requiring that the evidence be "kept" by the officer. Yet, items subject to that statute have been released to others under special circumstances (e.g., when needed for use in connection with a prose-

298. In some instances, depending upon the nature of the evidence involved and the size of the police force, the evidence may be placed in the custody of the prosecutor or even stored on private property. See also the discussion in the text at the paragraph following note 299 infra of section 21[2], on temporary return of seized property to its owner.

299. The Committee found no reason to shift the responsibility for determining the appropriate means of custody from the police to the court. The court may, of course, exercise supervisory control where there has been an abuse by police. The AlI proposal, ALI CODE, supra note 5, \& SS 280.2, requiring the issuance of a judicial "custody order" in almost all cases, was viewed as imposing an unproductive and wasteful requirement. 
cution in another district). ${ }^{300}$ Precise standards identifying those circumstances are difficult to formulate. Factors relating to administrative convenience, effective law enforcement, and the interests of third parties must be considered. The police and the prosecutor face a difficult situation, however, when the release determination is entirely their responsibility. Loss or alteration of the evidence may adversely affect the defendant's case, yet there is no ready means for determining in advance whether the defendant objects to the temporary release. Where the request comes from the ownercrime victim who claims an "urgent" need for his property, the police and prosecutor find themselves in a particularly awkward position because that person frequently is also the complaining witness. Accordingly, the Committee concluded that final authority to authorize temporary release should reside in the courts. The police may still permit release on their own decision if they are certain that the release would be consistent with their obligation to cause the item to be kept safely, but if they have any doubts, they can insist upon a judicial determination (as can a person whose claim is denied by the police).

Subsection [3] of proposed section 2I seeks more satisfactory guidelines primarily by indicating the relationship of the many current provisions that bear upon the disposition of seized matter no longer needed for prosecution purposes. Section 780.655 provides that "stolen or embezzled property" should be "restored to the owner," other "moneys" or "useful property" turned over to the political subdivision of the police department seizing the property, and any remaining "things" be disposed of as ordered by the court. Other provisions, however, modify these directives. Various provisions require that specified items be forfeited and disposed of in accordance with forfeiture provisions. ${ }^{301}$ In some cases, the forfeited property must be given to a specified agency or may be obtained by such agency upon request. ${ }^{302}$ Other provisions deal with the disposition of stolen property that is not claimed by the rightful owner. ${ }^{303}$ These provisions apparently further limit police authority to dispose of seized property. Section 21[3] seeks to bring the various provisions together in an orderly fashion so as to indicate the pos-

300. Discussion at Committee meeting of September 13, 1971.

301. See, e.g., Mrch. CoMp. LAws ANN. $\S \S 205.509$ (illegally possessed cigarettes); 286.18 (illegal apiary appliances); 300.12-.14 (illegally used hunting and fishing equipment).

302. See, e.g., Mrar. Comp. LAws ANn. $\$ \$ 28.434$ (1968) (illegally possessed weapons); 335.334(3) (Supp. 1974-1975) (controlled substances).

303. See, e.g., Mich. CoMP. Laws ANN. \$§ 28.401-.406, 434.171-.174 (1967). 
sible dispositions of all seized tangible items. ${ }^{304}$ Finally, it provides a procedure, again largely following current practice, for determining who shall receive seized property when more than one person claims a right to it.

\section{EXCLUSIONARY REMEDY}

The Committee considered various proposals relating to the exclusion of evidence obtained in violation of the proposed search and seizure statute, but decided against advancing a legislative proposal. The Committee was concerned only with the possible application of an exclusionary remedy to evidence obtained through violation of those proposed requirements that are not constitutionally mandated. Where police activities violate the Constitution as well as a statutory provision, $M a p p v$. Ohio ${ }^{305}$ already requires exclusion of all of the fruits of that violation. ${ }^{308}$

Some Committee members opposed any extension of the exclusionary rule to nonconstitutional violations. They argued that even if the exclusionary "remedy" is accepted as an appropriate deterrent to unlawful police conduct, all of the necessary deterrent impact is provided by the Mapp decision. Police officer training does not distinguish between those statutory requirements that are constitutionally mandated and those that are not, and officers are not likely to draw distinctions of that type in practice. These Committee members also rejected the contention that admission of illegally seized evidence would undermine the "imperative of judicial integrity." 307 They noted that a court cannot properly be viewed as ap-

304. Here again the Committee eliminated what appeared to be an anomalous procedural distinction in the treatment of searches with and without warrants. Mrcri. CoMP. LAwS ANN. \$ 780.655 (1968) includes no special provision for the automatic return of property (other than stolen property) seized pursuant to a warrant. Accordingly, such property may be returned to the person from whom it was seized only upon court order. On the other hand, property seized without a warrant is regularly returned without a court order, unless another person claims ownership or there is some other basis for doubting the person's right to the property, in which case a court order is obtained. Section $21[3]$ follows the latter procedure in permitting the police to return without a court order any tangible item (other than contraband or forfeited property) without regard to whether the seizure was made pursuant to a warrant. Where there is some question as to whether the property should be returned to the person from whom it was seized, the police may await a court order.

305. 367 U.S. 643 (1961).

306. Although Chief Justice Burger's dissenting opinion in Bivens v. Six Unknown Named Agents, 403 U.S. 388 (1971), suggests that a state might be able to provide a constitutionally acceptable alternative remedy for fourth amendment violations, any such remedy would require legislation extending beyond a revision of the Criminal Procedure Code. Accordingly, the Committee viewed adoption of such a proposal as a matter beyond the scope of its assigned task.

307. Mapp v. Ohio, 367 U.S. 643,669 (1961). 
proving illegality simply because it refuses to interrupt a proceeding to determine how particular evidence was obtained; the availability of civil remedies for violation of substantial statutory rights clearly indicates that illegal police action is not condoned.

Other members contended that the exclusionary remedy was the only feasible means of deterring police illegality and was necessary to avoid the appearance of judicial condonation of such illegality. They favored application of the exclusionary rule at least to bar evidence obtained through intentional violations of all substantial safeguards provided in the proposed statute, without regard to whether those safeguards are constitutionally mandated. ${ }^{308}$

A majority of the Committee members on both sides of the issue agreed, however, that legislation was unnecessary and perhaps inappropriate at this time. Committee members opposing the application of the exclusionary remedy noted that Michigan courts had applied the exclusionary remedy only to evidence obtained in violation of constitutional limitations on search and seizure. They found no indication in search and seizure decisions, or in decisions involving related areas of criminal procedure, that evidence obtained from violation of statutory provisions would be excluded on that ground alone. ${ }^{309}$ When the Michigan Supreme Court adopted a state rule similar to the federal $M c N a b b-M a l l o r y ~ r u l e, 310$ its decision was based on constitutional grounds as well as on the exercise of its supervisory authority to implement the prompt arraignment stat-

308. Cf. ALI CODE, supra note 5, § SS 290.2.

309. In People v. Sinclair, 387 Mich. 91, 121, 194 N.W.2d 878, 890 (1972) (Swainson, J.), a concurring justice favored application of an exclusionary rule, based on the "general supervisory powers of the court," to bar evidence obtained through police entrapment that might not violate the federal or state constitutions. The majority, however, did not reach that issue.

Subsequent to the Committee's determination, the Michigan Court of Appeals held that the results of a breathalyzer test administered to a person arrested illegally would not be suppressed where the arrest met fourth amendment standards but violated a state law permitting officers to make warrantless arrests only for misdemeanors committed in their presence. People v. Burdo, 56 Mich. App. 48, 223 N.W.2d 358 (1974). The court noted:

Defendant's arrest not being invalid in the constitutional sense and therefore not subject to the constitutionally mandated per se exclusionary rule, the question thus becomes whether this State, as a matter of its own public policy, should fashion a similar exclusionary rule with respect to statutorily illegal arrests. We have not

found any Michigan precedent which would mandate such a rule, nor do we find

that such a rule is necessary to protect the basic rights of one illegally arrested as was defendant herein.

56 Mich. App. at 52, 223 N.W.2d at 360-61.

310. See Mallory v. United States, 354 U.S. 449 (1957); McNabb v. United States, 318 U.S. 332 (1943). The McNabb-Mallory rule excluded from evidence incriminating statements made by a defendant during the time he was detained in violation of the federal prompt presentment requirement. See Y. Kamisar, W. LAFave \& J. ISRAEL, supra note 50, at 513-14. 
ute. ${ }^{311}$ In light of this precedent, members opposing an exclusionary rule found no need for a specific prohibition against exclusion. Indeed, some expressed concern that including such a provision in only this one chapter of the Criminal Procedure Code would raise doubts about the absence of similar provisions in other chapters.

Those favoring application of the exclusionary rule to violations of all substantial statutory safeguards also believed that a specific provision to that effect was not necessary in the setting of this chapter. $^{312}$ They noted that statutory violations most likely to lead to the discovery of evidence almost always would infringe upon constitutional safeguards protected by the Mapp decision. ${ }^{313}$ The one possible exception is the restriction upon entry without notice under section 11. The Supreme Court has held that the exclusionary rule will be applied to violations of a federal statute that provides less leeway than would the Constitution under Ker $v$. California. ${ }^{314}$ Members favoring the extension of the exclusionary

311. See People v. McCager, 367 Mich. 116, 116 N.W.2d 205 (1962); People v. Hamilton, 359 Mich. 410, 102 N.W.2d 738 (1960).

312. ALI CoDE, supra note 5 , \& SS 290.2 would apply the exclusionary remedy to evidence obtained through nonconstitutional violations under specified circumstances. However, almost all of the nonconstitutional grounds listed in that section relate to limitations that are not included in the Committee's proposals.

313. Moreover, violation of certain nonconstitutional provisions relating to the validity of the search warrant may result in constitutional violations. Thus, where a search is conducted pursuant to a warrant that is invalid under state law (e.g., because the issuing official was not authorized to issue warrants), the Constitution may require that the search be justified as a warrantless search even though the violated state limitation is not constitutionally required. Support for this position is found in cases holding unconstitutional searches conducted incident to arrests that meet fourth amendment requirements (that is, arrests that are based on probable cause) but fail to comply with state limitations on arrest authority. See, e.g., United States v. Di Re, 332 U.S. 581 (1948); United States v. Mills, 472 F.2d 1231 (D.C. Cir. 1972); Pcople v. Robinson, 388 Mich. 630, 633, 202 N.W.2d 288, 289-90 (1972) (T.G. Kavanagh, J., dissenting). But compare People v. Burdo, 56 Mich. App. 48, 223 N.W.2d 358 (1974), discussed in note 309 supra. On the other hand, some cases indicate that failure to comply with various warrant execution requirements does not "amount to deprivation of Fourth Amendment rights necessitating suppression." United States v. Cafero, 473 F.2d 489, 499 (3d Cir. 1973), cert. denied, 417 U.S. 918 (1974). See United States v. Moore, 452 F.2d 569 (6th Cir. 1971), cert. denied, 407 U.S. 910 (1972) (failure to include an item in the inventory attached to the return); United States v. McKenzie, 446 F.2d 949 (6th Cir. 1971) (failure to deliver a warrant at time of search as required by FED. R. Crim. $P$. 41(d); warrant delivered next day); United States v. Averell, 296 F. Supp. 1004 (E.D. N.Y. 1969) (twenty-eight month delay in filing warrant return and inventory). But compare State v. Montoya, 86 N.M. 119, 520 P.2d 275 (Ct. App. 1974).

314. 374 U.S. 23, 39 (1963). In Miller v. United States, 357 U.S. 301 (1958), the Supreme Court excluded evidence obtained after police had entered a dwelling in violation of a District of Columbia law based upon 18 U.S.C. $\$ 3109$ (1970). In Ker the Court indicated that Miller rested on the view that the illegal entry rendered the arrest unlawful; the subsequent search then fell because its only constitutional justification was a search incident to an arrest. Cf. note 313 supra. However, the Court in $\mathrm{Ker}$ also suggested that the exclusion of evidence in Miller rested on the exercise of 
rule were willing to leave possible adoption of a similar position in Michigan to the determination of the Michigan Supreme Court. ${ }^{315}$ They recognized that any general provision requiring application of an exclusionary remedy to nonconstitutional violations would be highly controversial, and did not consider it appropriate to advance such a proposal where its likely significance would be limited to section 11 .

\section{APPENDIX: PROPOSED PROVISIONS ON SEARCH AND SEIZURE}

\section{[Definition of terms]}

Section 1. The following definitions apply to this Chapter unless the context otherwise requires:

(a) "Building", in addition to its ordinary meaning, includes a structure of any type that is used for the lodging of persons therein or for carrying on any business therein; if a building consists of two or more units separately secured or occupied, each unit shall constitute a separate building.

(b) "Executing officer" includes a peace officer charged by the search warrant with its execution and such other persons as assist him in its execution pursuant to section 13.

(c) "Judicial district". The "judicial district" of a magistrate who is a district court judge, municipal judge, or Recorder's Court judge encompasses any geographical location in which, if a state offense were there committed, prosecution thereon could be initiated in the court on which the magistrate sits pursuant to state law defining the jurisdiction or criminal venue of that court. The judicial district of a magistrate who is a district court magistrate is the same as that of the district court which appointed the magistrate.

(d) "Local offense" includes any violation of an ordinance that is punishable by imprisonment.

(e) "Magistrate" includes each of the following: (i) a district court magistrate authorized to issue warrants by a district court judge under Section 8511 of Act No. 154 of the Public Acts of 1968, being Section 600.8511 of the Compiled Laws of 1970; (ii) a district court judge; (iii) a municipal court judge; (iv) a judge of Recorder's Court of Detroit who is designated, in accordance with the rules of that court, to consider applications for search warrants.

(f) "Matter" includes persons, tangible items, and incorporeal information.

(g) "Offense" includes any state offense or local offense.

(h) "Peace officer" includes any member of a police force or other organization of a city, county, township, village or of the state, who is regularly employed as such and is responsible for the prevention and

the court's supervisory power. See 374 U.S. at 31, 39. See also State v. Linder, 291 Minn. 217, 219-21, 190 N.W.2d 91, 93-94 (1971).

315. In People v. Doane, 33 Mich. App. 579, 584, 190 N.W.2d 259, 261 (1971), the court found no need to decide "whether technical noncompliance with Mrar. CoMP. LAws ANN. \& 780.656 (1968) would render the evidence inadmissible "even though defendant's 4th amendment rights were not violated thereby." 
detection of crime and the enforcement of the general criminal laws of the state, but shall not include any person serving as such solely by virtue of his occupying any other office or position. Peace officer also includes any public employee vested by law with the duty to enforce a specific criminal law when engaged in a search designed to investigate the possible violation of that law.

(i) "Place" includes any vehicle, object, building or premises.

(j) "Private building" includes any building or enclosed portion thereof that reasonably should be recognized as not open to the public at the time of entry.

(k) "Prosecuting attorney" includes a prosecuting attorney for a county, an assistant prosecuting attorney for a county, the Attorney General, the deputy Attorney General, an assistant Attorney General, a special prosecutor appointed pursuant to section $\longrightarrow$, and, in connection with a prosecution for a local offense, an attorney for the political subdivision that enacted the ordinance.

(1) "Seizure" includes the obtaining of incorporeal information by sensory perception through a search.

(m) "State offense" includes any crime proscribed by state law.

(n) "Stolen" property includes any property obtained from another in violation of any criminal law of this state.

[Search warrants; authority to issue a warrant]

Section 2[1]. A search warrant may be issued by any magistrate. $A$ magistrate may refuse, however, to consider an application for a search warrant, or to issue a search warrant, on either of the following grounds: (a)(i) The warrant is sought to seize matter relating to a state offense not alleged to have been committed within the judicial district of the magistrate, and to search a place or person not al. leged to be located within the judicial district of the magistrate; and (ii) no showing has been made that all magistrates of the judicial district in which the offense allegedly was committed, or the place or person allegedly is located, are unavailable.

(b) Another magistrate from the same judicial district has been designated to consider warrant applications and no showing has been made that that magistrate is unavailable.

[2] Any judge of a court of record, in addition to those designated in section 1(e), may exercise the authority of a magistrate provided for in this Chapter, but rulings of a judge acting in that capacity shall be subject to review in the same manner as the rulings of a magistrate of the judicial district within which the place or person to be searched is located.

[Search warrants; availability of magistrates]

Section 3. The presiding judge of each circuit court shall designate at least one magistrate in each county of the circuit who shall be available at all times to consider applications for search warrants. The presiding judge of Recorder's Court shall designate at least one judge of that court who shall be available at all times to consider applications for search warrants.

[Search warrants; who may apply]

Section 4. Application for a search warrant may be made only 
by a prosecuting attorney or peace officer.

[Search warrants; contents of application]

Section 5[1]. Except as provided in subsection [4], an application for a search warrant shall be in the form of an affidavit sworn to before the magistrate.

[2] The affidavit shall contain each of the following:

(a) The name of the court requested to issue the warrant.

(b) The name and title of the applicant.

(c) A statement that there is reasonable cause to believe that matter subject to seizure under section $6[1]$ will be found in or upon a described place or person, or both. The matter to be seized shall be described with reasonable particularity in light of its nature and the nature of the state offense allegedly committed. The place or person to be searched shall be described with sufficient particularity so as to identify a definitely ascertainable place or person.

(d) Allegations of fact establishing reasonable cause. The basis for the allegations must be stated, but the basis may be either personal knowledge of the applicant or reliable information obtained from a credible person, named or unnamed. If the allegations are based in whole or in part upon information obtained from others, including peace officers, the affidavit must set forth facts evidencing the reliability of such information, including facts bearing on the informant's credibility and the means by which the informant obtained the information. The applicant also may submit affidavits of other persons containing allegations of fact supporting those contained in the applicant's affidavit.

(e) A request that the magistrate issue a search warrant directing a search of the described place or person for the purpose of finding and seizing the described matter.

[3] The affidavit may also contain any or all of the following:

(a) A request that an extended period for execution of the warrant be granted pursuant to section 9[2]. The request must be supported by allegations of fact, of a kind prescribed in subsection [2](d), establishing the conditions specified in section 9[2].

(b) A request that the executing peace officer be authorized under section 10 to enter a private building without giving prior notice of his authority and purpose. The request must be supported by allegations of fact, of a kind prescribed in subsection [2](d), establishing the conditions specified in section 10 .

[4] In lieu of the affidavit required under subsection [1], an oral statement, made under oath by an applicant not in the physical presence of the magistrate, shall constitute an acceptable application for a search warrant if each of the following conditions are met:

(a) The magistrate finds, based upon the statement of the applicant, that there is reasonable cause to believe that (i) the presentation of the applicant's affidavit to a magistrate would result in delay in obtaining a search warrant and in executing 
a search pursuant thereto, and (ii) such delay might result in loss or destruction of matter subject to seizure under section $6[1]$.

(b) The application by oral statement has been approved by a prosecuting attorney.

(c) The oral statement is communicated directly to the magistrate by radio, telephone, or other appropriate means, and a verbatim record of the oral statement is made by a recording process subject to the exclusive control of the magistrate or his staff, though the recording equipment need not be located within the offices of the magistrate or his staff.

(d) Without unnecessary delay the verbatim record is transcribed at the direction of the magistrate, certified by the magistrate and the applicant, and both the transcription and original recording are filed in the same manner as an affidavit.

An application presented in the form of a sworn oral statement shall be subject to all of the requirements of subsections [2] and [3] as to the contents of an application.

[Search warrants; matter subject to seizure]

Section 6[1]. A warrant may be issued to search for and seize any of the following matter.

(a) Stolen property.

(b) Tangible items designed and intended for use as, or presently or previously used as, instrumentalities in the commission of a state offense.

(c) Tangible items possessed, controlled, or used wholly or partially in violation of any criminal law of this state. (d) Contraband.

(e) The bodies of human beings or of animals, who may be the victims of a state offense.

(f) Matter that may constitute evidence tending to demonstrate that a state offense was committed or that a particular person participated in the commission of a state offense.

(g) A person unlawfully held in confinement or other restraint.

(h) A person for whom an arrest warrant has been issued.

[2] An officer executing a warrant may also seize pursuant to section 15 any matter that may constitute evidence tending to demonstrate that a local offense was committed or that a particular person participated in the commission of a local offense.

[Search warrants; determination of application]

Section 7[1]. If the magistrate is satisfied that the application meets the requirements of section 5 , and there is reasonable cause to believe that matter described in the application will be found in or upon a place or person described in the application, the magistrate shall grant the application and issue a search warrant directing the search of said place or person and seizure of such matter by a peace officer. In ruling on an application for a search warrant, the magistrate shall examine the applicant and may examine any other person believed to possess relevant information. A finding that reasonable cause exists, however, may be based only on information contained in the application and any supporting affdavits.

[2] If the magistrate denies the application, any subsequent appli- 
cation to search for the same or similar matter in or upon the same place or person shall be presented to the same magistrate, if he is available. If that magistrate is unavailable, the application shall note that a previous application was denied and shall contain a copy of that previous application.

[3] A search warrant shall be issued with all practicable secrecy, and, prior to the execution of the warrant, neither the warrant, the application, nor any supporting affidavit shall be made public except (i) as is reasonable to secure execution of the warrant, (ii) upon order of the magistrate or, (iii) upon order of any other court preliminary to or in connection with a judicial proceeding pending before that court.

[4] If the application for a warrant was by oral statement pursuant to section 5[4], and the magistrate issues the warrant, he shall orally authorize a peace officer to sign the magistrate's name on a duplicate of the original warrant. The authorization shall be recorded verbatim, and transcribed, certified, and filed as provided in section 5[4]. The duplicate search warrant shall be clearly designated as a true copy and state that the signing of the magistrate's name thereon was authorized by order of the magistrate. A duplicate warrant is a search warrant for the purposes of this Chapter and shall be served and returned as provided in sections 12 and 13 . Upon return of the duplicate warrant, it shall be filed by the court along with the original warrant.

[Search warrants; contents of warrant]

Section 8. A search warrant shall contain each of the following: (a) The name of the issuing court, the subscription of the issuing magistrate, and the date of issuance.

(b) The name, department, or classification of any peace officer directed to execute the warrant. The magistrate may direct that the warrant be executed by any peace officer within the state.

(c) A description of the matter to be seized that is reasonably particular in light of the nature of the matter and the nature of the state offense allegedly committed.

(d) A description of a place or person, or both, to be searched. The description shall be suffciently particular to identify a definitely ascertainable place or person.

(e) The name of the person upon whose application the warrant is issued and the name of any person whose affidavit was filed in support of that application.

(f) A statement of the facts establishing the reasonable cause on which the warrant is issued, or in lieu of such statement, a copy of the application and any supporting affidavits may be attached to the warrant.

(g) A direction that the warrant be executed on or before a date specified in accordance with section 9 .

(h) A direction that the warrant be executed consistent with the notice and entry requirements of section 11, or, if the court has so determined pursuant to section 10 , a direction that the executing officer may enter a private building without giving prior notice of his authority and purpose. 
(i) A direction that a copy of the warrant and a receipt for any tangible item seized be served as provided in sections 12 and 20.

(j) A direction that the warrant be returned as provided in section 14

[Search warrants; time of execution]

Section 9[1]. The warrant may be executed at any time of day or night. Except as provided in subsection [2], the warrant shall be executed on or before a date specified in the warrant, but no later than five days after the date of issuance.

[2] If the magistrate finds reasonable cause to believe that a place or person to be searched is difficult of speedy access, he may make the warrant executable on or before a date no later than ten days after the date of issuance.

[3] A search initiated during the time period prescribed under subsections [1] or [2] need not be completed within that time period, provided the search is not extended beyond a period reasonably necessary for its completion. A search may be conducted intermittently if a continuous search is not reasonably practicable under the circumstances.

[Search warrants; authorization of entry without notice]

Section 10 . The magistrate may authorize the executing officer to enter a private building without giving the prior notice of his authority and purpose otherwise required under section $11[1]$ if the magistrate finds reasonable cause to believe that any of the following conditions exist:

(a) Giving prior notice is likely to result in the destruction or disposal of the matter subject to seizure.

(b) Giving prior notice is likely to endanger the safety of the officer or another person.

(c) The officer also desires to enter the building for the purpose of making an arrest pursuant to a warrant, and the arrest warrant authorizes entry without giving prior notice pursuant to section 110 .

[Search warrants; notice and entry in execution]

Section 11[1]. Except as provided in subsection [2], the executing offcer, before entry into a private building for the purpose of conducting a search, shall give notice of his authority and purpose in an appropriate manner.

[2] The executing officer may enter a private building without giving prior notice of his authority and purpose under any of the following conditions:

(a) The warrant expressly authorizes entry without prior notice pursuant to section 10 .

(b) Circumstances known to the officer at the time of entry, but unknown at the time of application for the warrant, give the officer reasonable cause to believe that giving prior notice is likely to endanger the safety of the officer or another person.

(c) The officer also enters the building for the purpose of making an arrest, and section 118 permits entry for that purpose without giving prior notice.

[3] An executing officer may not enter a private building without consent unless one of the following conditions exists: 
(a) The officer may enter without giving prior notice pursuant to subsection [2].

(b) After giving notice of his authority and purpose, the offcer is not admitted within a reasonable time.

(c) After giving notice of his authority and purpose, the offcer has reasonable grounds to believe, based upon the response of an occupant, that reasonably prompt admission will be denied or that to further delay entry is likely to endanger the safety of the officer or another person.

[4] Before executing a search warrant directing a search of a person, the executing officer shall give notice of his authority and purpose to that person unless encountering physical resistance, flight, or other circumstances rendering notification impracticable.

[Search warrants; service of warrant copy]

Section 12. A copy of the warrant shall be served by the executing officer at the time of the search or as soon thereafter as is reasonably practicable. If the search is of a place, the executing officer shall give a copy of the warrant to any person present who is in apparent control of the place. If no such person appears to be present, the officer shall post a copy of the warrant at the place. If the search is of a person, the officer shall give a copy of the warrant to the person.

[Search warrants; assistance of others in execution]

Section 13. A peace officer directed to execute a warrant may be accompanied and assisted by such other persons as may be reasonably necessary for the successful execution of the warrant.

[Search warrants; return of warrant]

Section 14[1]. If the warrant is executed, the executing officer, without unnecessary delay, shall return to the magistrate the following:

(a) The warrant, with date and time of execution noted thereon.

(b) If a receipt was issued, a copy thereof.

[2] If the warrant was not executed within the time specified therein, the officer shall return the warrant within two days thereafter and note thereon the lack of execution and the reason therefor.

[Search warrants; incidental searches and seizures]

Section 15. In addition to the matter specified in the warrant, an executing officer may seize any other matter, discovered in the reasonable course of a search pursuant to the warrant, that he has reasonable cause to believe to be subject to seizure under section 6 . Tangible items seized pursuant to this section shall be included in the receipt filed pursuant to section 14, but no additional warrant shall be required to authorize such seizure.

[Searches without a warrant; search incident to an arrest]

Section 16[1]. A peace officer making a lawful arrest, or an officer assisting him, may conduct a reasonable search of the person arrested and the area within that person's immediate control.

[2] A peace officer conducting a search pursuant to subsection [1] may seize the following matter dis- 
covered in the reasonable course of the search:

(a) Matter that the officer has reasonable cause to believe to be subject to seizure under section 6 .

(b) Any weapon or similar item that the officer reasonably believes to be capable of use in attacking a person or attempting an escape.

[3] A private person making a lawful arrest may search the person arrested and the area within that person's immediate control, to the extent reasonably necessary to fulfill the following purposes:

(a) Protecting the private person or any other person present from attack.

(b) Preventing the arrested person from escaping.

(c) Discovering and seizing the fruits of, or instrumentalities used in the commission of, the offense for which the arrest was made.

[4] A private person conducting a search pursuant to subsection [2] may seize the following matters discovered in the reasonable course of the search:

(a) Any weapon or similar item that the private person reasonably believes to be capable of use in attacking a person or attempting an escape.

(b) Matter reasonably believed to constitute the fruits of, or instrumentalities used in the commission of, the offense for which the arrest was made.

Any matter seized by a private person shall be delivered to a peace officer, along with the arrested person, as provided in section 120[3].
As soon thereafter as is reasonably practicable, the peace officer shall sign and deliver to the arrested person a receipt itemizing the tangible things received.

[Searches without a warrant; custodial search]

Section 17[1]. A lawfully arrested person confined in a jail or a similar detention facility may be searched to the extent reasonably necessary for custodial purposes. A vehicle or object lawfully taken into custody may be searched to the extent reasonably necessary for custodial purposes.

[2] A person conducting a search pursuant to subsection [1] may seize, in addition to matter that may be taken for custodial purposes, any other matter discovered in the reasonable course of the cus. todial search that he has reasonable cause to believe to be subject to seizure under section 6 . If such matter is seized by a custodial official other than a peace officer, it shall promptly be delivered to a peace officer for safekeeping as provided in section 21. As soon thereafter as is reasonably practicable, the peace officer shall sign and deliver to the arrested person a receipt itemizing the tangible things received.

[Searches without a warrant; other grounds]

Section 18[1]. A peace officer having reasonable cause to believe that matter subject to seizure under section $6[1]$ may be found in or upon any designated place or person may search that person or place without a warrant if justified by exigent circumstances.

[2] A peace officer conducting a 
search pursuant to subsection [1] may seize any matter discovered in the reasonable course of the search that he has reasonable cause to believe to be subject to seizure under section 6 .

[3] Before entry into a private building for the purpose of conducting a search pursuant to subsection [1], a peace officer shall give notice of his authority and purpose in an appropriate manner, unless any of the following circumstances exist:

(a) The officer has reasonable cause to believe that giving prior notice is likely to endanger the safety of the officer or another person.

(b) The officer also desires to enter the building for the purpose of making an arrest and sections 110 or 118 permit entry for that purpose without giving prior notice.

Before conducting a search of a person pursuant to subsection [1], a peace officer shall give notice of his authority and purpose to that person unless encountering physical resistance, flight, or other circumstances rendering notification impracticable.

[4] An officer may not enter a private building without consent for the purpose of conducting a search pursuant to subsection [1] unless one of the conditions specified in section $11[3]$ exists.

[Use of force]

Section 19. A person lawfully conducting a search pursuant to any provision of this Chapter may use such physical force against a person or property as is reasonably necessary successfully to execute the search; but deadly physical force may be used only if the person reasonably believes such force to be necessary to defend himself or a third person from the use or im. minent use of deadly physical force.

\section{[Receipt for seized items]}

Section 20. A peace officer seizing a tangible item as subject to seizure under section 6 shall, as soon thereafter as is reasonably practicable, prepare, sign, and serve a receipt specifying the item seized and indicating the time and date of the seizure. If the tangible item is taken from a person, the receipt shall be given to that person. If the tangible item is taken from a place, the receipt shall be given to any person present who is in apparent control of the place. If no such person appears to be present and the place appears to be regularly unoccupied, the receipt shall be forwarded to the owner. If the owner's address is unknown or the place appears to be regularly occupied, the receipt shall be posted at the place.

[Custody and disposition of seized matter]

Section 21[1]. Except as provided in subsection [2], a peace officer seizing or receiving a tangible item subject to seizure under section 6 shall cause such item to be kept safely so long as necessary for its use in a criminal prosecution.

[2] After notice to the prosecuting attorney and defendant, any court before which a criminal prosecution is currently pending may issue an order directing the release of a tangible item retained pursuant to subsection [1]. An order issued pursuant to this subsection shall be consistent with the 
possible use of the item in the criminal prosecution and may include the following:

(a) A direction to temporarily transfer the item to another court where the item is required as evidence in a prosecution before that court.

(b) A direction to return the item to its owner on condition that he will retain it and return it for use in the criminal prosecution.

[3] When a tangible item retained pursuant to subsection [1] is no longer required for use in a criminal prosecution, it shall be disposed of as follows:

(a) Items subject by statute to forfeiture shall be disposed of as provided by such statute.

(b) Items constituting contraband shall be destroyed, except that any items capable of innocent use may be sold or retained for use when sale is inappropriate. The receipts from any sale shall be distributed in the same manner as the receipts from unclaimed property distributed pursuant to part (d) of this subsection.

(c) Stolen property shall be restored to the rightful owner. If ownership of the property is disputed, the court having jurisdiction to try the offense involved shall determine who is the rightful owner. Any person claiming to be the owner, and knowing that another also claims ownership, shall file a motion before the court requesting receipt of the property, and give notice of the motion to all other known claimants. (d) Stolen property which is unclaimed shall be disposed of as provided by the law applicable to the governmental department employing the peace officer who seized or originally received the property.

(e) All other property shall be returned to the person from whose person or premises the property was seized unless otherwise directed by the court having jurisdiction to try the offense involved. If the right to receive the property is disputed, the court shall determine the proper disposition of the property. Any person claiming a right to receive the property, and knowing that another person also claims that right, shall file a motion before the court requesting receipt of the property, and give notice of the motion to all other known claimants.

Evidence introduced in a judicial proceeding shall not be subject to disposition under this subsection except as directed by the court before which the evidence was introduced.

[Order for nontestimonial identification]

Section 22[1]. As used in this section, an "identification order" is an order directing a person to participate in a nontestimonial identification procedure in any of the following ways:

(a) Trying on clothing or other articles.

(b) Submitting to the taking of photographs.

(c) Submitting to the taking of fingerprints, footprints, palm 
prints, and other body impressions.

(d) Submitting to the taking of specimens of blood, urine, saliva, breath, hair, and nails, if the taking does not involve an unreasonable intrusion upon the body.

(e) Providing handwriting and voice exemplars.

(f) Submitting to body measurements and other reasonable body surface examinations.

[2] An identification order may be issued only by a Circuit Court or Recorder's Court judge. A Circuit Court judge may issue an identification order only in connection with the alleged commission of a state offense that would be triable within the Circuit. A Recorder's Court judge may issue an identification order only in connection with the alleged commission of a state offense that would be triable in Recorder's Court.

[3] Application for an identification order may be made only by a prosecuting attorney or peace officer. The application shall be in the form of an affidavit sworn to or affirmed before the court. The affidavit shall contain each of the following:

(a) The name of the court requested to issue the order.

(b) The name and title of the applicant.

(c) The name of the designated person whose participation in an identification procedure is requested.

(d) The particular identification procedure in which his participation is requested and the scope of that participation.

(e) A statement that there is reasonable cause to believe each of the following:

(i) That a state offense has been committed.

(ii) Either that the designated person committed such offense, or that one of a grouping of not more than several persons committed the offense and the designated person falls within that grouping.

(iii) That the information to be obtained from the requested identification procedure will be of material aid in determining whether the designated person committed the offense.

(iv) That the information to be obtained from the designated person's participation in the identification procedure cannot be obtained practicably from a law enforcement agency or other public official or agency.

(f) Allegations of fact, of a kind prescribed in section 5[2](d), establishing the reasonable cause alleged in paragraph (e) of this subsection. The applicant also may submit affidavits of other persons containing allegations of fact supporting those contained in the applicant's affidavit.

[4] The affidavit also may contain a request that the order direct the designated person to be taken into custody and brought forthwith before the court for the purpose of requiring immediate participation in the identification procedure. Such request must be supported by allegations of fact, of a kind prescribed in section 5[2](d), establishing reasonable cause to believe either that: 
(i) The designated person will, upon service of the order, either flee or alter or destroy a physical characteristic to be examined.

(ii) The evidence sought will be lost if the procedure is not conducted forthwith.

[5] In ruling on the application, the court shall examine the applicant and may examine any other person believed to possess relevant information. A finding that reasonable cause exists, however, may be based only on information contained in the application and any supporting affidavits.

[6] If the court is satisfied that the application meets the requirements of subsection [3], and that reasonable cause exists with respect to each of the elements specified in paragraph (e) of subsection [3], the court shall issue an order directing the designated person to participate in the requested identification procedure. If the court also finds that reasonable cause exists with respect to the issuance of an order requiring immediate participation, as specified in subsection [4], it shall direct that a peace officer take custody of the designated person and bring him forthwith before the court. Upon presentation of the designated person, the court shall read the order to him and give him a reasonable time to consult with a lawyer. The court also shall inform the designated person that any challenge or request for modification must be presented promptly, and that if the order is not vacated or modified, the designated person will be directed to participate forthwith in the authorized procedure.

[7] The order of the court shall contain each of the following: (a) The name of the issuing court, the subscription of the issuing judge, and the date of issuance.

(b) The name of the person upon whose application the order was issued and the name of any person whose affidavit was filed in support of that application.

(c) A statement of the facts establishing the reasonable cause on which the order was issued, or, in lieu of such a statement, a copy of the application and any supporting affidavits may be attached.

(d) A direction that the designated person be at a particular place at a specified time and submit to a specified identification procedure. Unless the court issues an order requiring forthwith participation pursuant to subsection [4], the time specified for participation shall be at least three days after the service of the order.

(e) A direction that a person identified by name or classification conduct the specified identification procedure. The procedure may be conducted by a peace officer or other person designated by the court, except that the taking of a blood specimen shall always be conducted under medical supervision. Medical supervision may also be required for any other procedure as appropriate. The court may also require that specific methods be employed in administering the identification procedure, including, but not limited to, the requirement that the administration of the procedure be filmed, photographed, or otherwise recorded. 
(f) A direction that the designated person be detained no longer than a specified period which is reasonably necessary to conduct the procedure.

(g) A direction that the designated person not be subjected to investigative interrogation in the absence of counsel during the period of his appearance.

(h) A direction that the order be served within five days of its issuance, or, if the court has found reasonable cause to believe that it may be difficult to promptly locate the designated person, a direction that the order be served within ten days of its issuance.

(i) A direction that the order be returned as provided in subsection [8].

(j) A statement informing the designated person that he will be under no legal obligation to submit to interrogation or make any statement during the period of his appearance, except for such statement as may be required for voice identification.

(k) A statement informing the designated person that he may be accompanied by counsel and, if the designated person cannot afford to obtain counsel and requests the assistance of counsel, the court will appoint counsel to assist him.

(l) A statement informing the designated person that any attempt to alter substantially the physical characteristics to be examined in the identification procedure constitutes a violation of the order.

(m) A statement informing the designated person of his rights under subsection [10]. (n) A statement informing the designated person that he may request that the court make a reasonable modification of the order with respect to time, place, or manner of conducting the procedure, including a modification to have the identification procedure conducted at the designated person's place of residence where practicable.

(o) A statement informing the designated person that he may challenge the order on the ground that it was improperly issued.

(p) A statement informing the designated person of the procedure to be followed if he desires to request the assistance of a lawyer provided by the court, request modification of order, or challenge the order.

(q) A statement informing the designated person that if he fails to comply with the order, he may be held in contempt.

[8] The identification order shall be served by a peace officer by personally delivering a copy to the designated person. If the order is not served within the time specified, it shall be returned to the court within two days thereafter. The return shall note the lack of service and the reason therefor. If the order is served, but the designated person does not participate in the identification procedure as directed, the order shall be returned thereafter, without unnecessary delay. The return shall note the service of the order, the lack of implementation, and the reason therefor, if known. If the order is served and the designated person participates in the identification procedure, the order shall be returned thereafter, without unneces- 
sary delay. The return shall note the service of the order, its implementation, and shall contain a summary of the evidence obtained from the procedure.

[9] An identification order shall be issued with all practicable secrecy, and prior to the service of the order, neither the order, the application, nor any supporting affidavit shall be made public except (i) as is reasonable to serve the order, (ii) as directed by the court that issued the order, or (iii) as directed by any other court preliminary to or in connection with a judicial proceeding pending before that court.

[10] The designated person shall be given a copy of the results of any scientific testing procedure as soon as those results are available. If, within 30 days following his participation in the procedure, the designated person has not been charged with the offense specified in the application or a related offense, all evidence and records obtained from the identification procedure shall be destroyed promptly. The court may, however, on a showing of good cause, extend the period during which the records and evidence may be retained as is reasonably necessary to facilitate a continuing investigation or prosecution. Notification of the destruction of the records and evidence shall be filed with the court by the applicant. A copy of the notification shall be sent to the designated person.

[Order directing prosecutor participation in a nontestimonial identification procedure]

Section 23[1]. Upon application of an accused person, a Circuit
Court judge or Recorder's Court judge may issue an order directing a prosecuting attorney to provide a specified identification procedure for participation therein by the applicant. The order may require that the prosecutor provide any identification procedure that could be ordered pursuant to section 22[1]. A Circuit Court judge may issue an order upon application of an accused person only in connection with an alleged state offense that would be triable within the Circuit. A Recorder's Court judge may issue such an order only in connection with an alleged state offense that would be triable in Recorder's Court.

[2] An application for issuance of an order pursuant to this section shall be in the form of an affidavit, sworn to before the court. The affidavit must contain each of the following:

(a) The name of the court requested to issue the order.

(b) The name of the applicant and the particular identification procedure in which he desires to participate.

(c) A statement that the applicant either (i) has been charged with commission of a state offense through issuance of a complaint, information or indictment, or (ii) is the subject of an investigation by a peace officer or prosecuting attorney relating to the commission of a state offense.

(d) A statement that there is reasonable cause to believe that the results of the requested identification procedure will be of material aid in determining whether the applicant committed the offense specified in paragraph (c). 
(e) Allegation of fact, of a kind prescribed in section 5[2](d), establishing the applicant's status under paragraph (c) and the reasonable cause alleged in paragraph (d).

[3] If the court is satisfied that the application meets the requirements of subsection [2], that the applicant meets the requirements of paragraph (c) of subsection [2], and that reasonable cause exists as alleged in paragraph (d) of subsection [2], it shall issue an order directing the prosecuting attorney to provide the requested identification procedure for participation therein by the applicant. In ruling on the application, the court may request that a prosecuting attorney file a sworn response thereto, which the court may consider in making its ruling.

[4] The order of the court shall contain each of the following:

(a) The name of the issuing court, the subscription of the issuing judge, and the date of issuance.

(b) The name of the person upon whose application the order was issued.

(c) A statement of the facts upon which the order was issued, or, in lieu of such a statement, a copy of the application may be attached.

(d) A direction that the prosecuting attorney provide a specified identification procedure for participation therein by the applicant.

(e) The particular place and time at which the procedure shall be conducted. The specified time shall be at least three days after service of the court's order on the prosecuting attorney.

(f) A direction that the procedure be conducted in accordance with such methods as are specified by the court. The court shall require that any blood test be conducted under medical supervision, and may impose such further requirements as may be imposed under section 22[7](d).

(g) A direction that the identification procedure be conducted with reasonable promptness.

(h) A direction that the applicant not be subjected to investigative interrogation in the absence of counsel during the period of his appearance.

(i) A direction that the order be served and returned as required under subsections [5] and [6].

(j) A direction that the applicant be permitted to be accompanied by counsel.

[5] The court's order shall be served by personal delivery to the prosecuting attorney or by mailing a copy to the prosecuting attorney.

[6] If the identification procedure is not provided as required by the court order, the applicant shall promptly return the order to the court, together with a statement of the reason why it was not implemented, if known. If the identification procedure is provided, the prosecuting attorney shall thereafter return the order to the court, without unnecessary delay. The return shall note the implementation of the order and shall contain a summary of the evidence obtained from the procedure.

[7] The applicant shall be given a copy of the results of any scien- 
tific testing as soon as the results are available. If the applicant is a person specified in paragraph (c)(ii) of subsection [2] and is not charged with the commission of a state offense relating to the identification procedure within 30 days following his participation therein, all evidence and records obtained from the identification procedure shall be destroyed promptly. The court may, upon a showing of cause, extend the period during which the records and evidence may be retained as is reasonably necessary to facilitate a continuing investigation or prosecution. Notification of the destruction of the records and ev. idence shall be filed with the court by the prosecuting attorney. A copy of the notification shall be sent to the applicant. 